Huchon, P., Taylor, B., and Klaus, A. (Eds.)

Proceedings of the Ocean Drilling Program, Scientific Results Volume 180

\section{Geochemical and Mineralogical Evidence for the Provenance of Mixed VOLCANOGENIC/TERRIGENOUS Hemipelagic Sediments in the Pliocene- Pleistocene Woodlark Backarc Rift BASIN, SOUTHWEST PACIFIC: OCEAN Drilling Program Leg 180'}

Alastair H.F. Robertson ${ }^{2}$ and Timothy R. Sharp ${ }^{3}$

\begin{abstract}
Middle Miocene to Holocene fine-grained argillaceous sediments (clays, claystones/muds, and mudstones), which volumetrically dominated the sediment recovery in the Woodlark Basin during Leg 180, were chemically analyzed for major elements, trace elements, and some rare earth elements by X-ray fluorescence. Selected samples also underwent X-ray diffraction (XRD) analysis for mineral determination. The results shed light on sediment provenance when combined with shipboard sediment descriptions, smear slide study, and XRD. The oldest sediments recovered (Site 1108) of middle-late Miocene age include volcanogenic muds with distinctive high $\mathrm{MgO}$ and $\mathrm{K}_{2} \mathrm{O}$, indicative of a relatively basic calc-alkaline source related to an inferred Miocene forearc succession. The forearc basement, composed of diabase and basalt, was locally exposed (Site 1109) and eroded in the late Miocene $(<5.4-9.93 \mathrm{Ma})$, giving rise to fluvial conglomerates (Sites 1109, 1115, and 1118). Chemically distinctive fine-grained claystones and siltstones (with relatively high $\mathrm{Ti}$, low $\mathrm{K}$ ) are compatible with derivation from tropically weathered basic igneous rocks, correlated with the Paleogene Papuan ophiolite. Overlying latest Miocene-Pleistocene fine-grained
\end{abstract}

${ }^{1}$ Robertson, A.H.F., and Sharp, T.R., 2002. Geochemical and mineralogical evidence for the provenance of mixed volcanogenic/terrigenous hemipelagic sediments in the Pliocene-Pleistocene Woodlark backarc rift basin, southwest Pacific: Ocean Drilling Program Leg 180. In Huchon, P., Taylor, B., and Klaus, A. (Eds.), Proc. ODP, Sci. Results, 180, 1-53 [Online]. Available from World Wide Web: $<$ http://www-odp.tamu.edu/ publications/180_SR/VOLUME/ CHAPTERS/156.PDF> [Cited YYYYMM-DD]

2Department of Geology and Geophysics, West Mains Road, University of Edinburgh, EH9 3JW, United Kingdom.

ahfr@ginger.glg.ed.ac.uk

${ }^{3}$ University of Technology, Sydney, P.O. Box 123, Broadway, Sydney 2007, NSW, Australia.

Initial receipt: 19 December 2000 Acceptance: 16 October 2001

Web publication: 12 March 2002

Ms 180SR-156 
sediments throughout the Woodlark Basin were partly derived from calc-alkaline volcanic sources. However, relatively high abundances of $\mathrm{Al}_{2} \mathrm{O}_{3}$ and related element oxides $\left(\mathrm{K}_{2} \mathrm{O}\right.$ and $\left.\mathrm{Na}_{2} \mathrm{O}\right)$ and trace elements (e.g., $\mathrm{Rb}$ and $\mathrm{Y}$ ) reflect an additional terrigenous input throughout the basin, correlated with pelitic metamorphic rocks exposed on Papua New Guinea and adjacent areas. In addition, sporadic high abundances of $\mathrm{Cr}$ and $\mathrm{Ni}$, some other trace metals, and related minerals (talc, crysotile, and chlorite) reflect input from an ophiolitic terrain dominated by ultramafic rocks, correlated with the Paleogene Papuan ophiolite. The source areas possibly included serpentinized ultramafic ophiolitic rocks exposed in the Papua New Guinea interior highlands. Chemical evidence further indicates that fine-grained terrigenous sediment reached the Woodlark Basin throughout its entire late Miocene-Holocene history. Distinctive high-K volcanogenic muds rich in tephra and volcanic ash layers that appear at $<2.3 \mathrm{Ma}$ (Sites 1109 and 1115) are indicative of high-K calc-alkaline volcanic centers, possibly located in the Dawson Strait, Moresby Strait, or Dobu Seamount area. Chemical diagenesis of fine-grained sediments within the Woodlark Basin is reflected in clay neomorphism and localized formation of minerals including dolomite, ankerite, and zeolite but has had little effect on the bulk chemical composition of most samples.

\section{INTRODUCTION}

During Leg 180 (June-August 1998), a nearly north-south transect of six holes, with good recovery, was drilled across the Woodlark Basin, from the footwall (represented by the Moresby Seamount, across the western Woodlark rift basin) to the downflexed northern margin of the rift (Figs. F1, F2). The objective here is to utilize chemical and mineralogical evidence of mainly hemipelagic sediments from the Woodlark Basin to infer sediment provenance. The results supplement information on sediment composition and provenance obtained by shipboard observations (Taylor, Huchon, Klaus, et al., 1999) and a study of thin sections of the coarser grained silts/siltstones and sand/sandstone from the Woodlark Basin (see Sharp and Robertson, this volume; see Cortesogno et al., this volume). Fine-grained sediments (clays, muds, and silts) are estimated to account for $>80 \%$ of the total sediment volume recovered in the Woodlark Basin and thus are important for understanding depositional processes and sediment provenance within the basin as a whole.

\section{REGIONAL GEOLOGICAL SETTING}

The western Woodlark Basin is one of the best areas to study the processes of rifting as a precursor to seafloor spreading. It is one of the few areas of the world where a very strong case can be made for rifting related to large-scale simple shear on a relatively low-angle $\left(\sim 30^{\circ}\right)$ extensional detachment fault (Taylor et al., 1995). Extension was achieved by westward propagation of a spreading center into the previously rifted continental crust of Papua New Guinea (Benes et al., 1994; Taylor et al., 1999). A preexisting subduction-related arc, the Miocene Trobriand arc, was rifted at $\sim 6-8 \mathrm{Ma}$ to form the Pliocene-Pleistocene western Woodlark rift basin, adjacent to Papua New Guinea (Weissel et al., 1982; Taylor et al., 1999). Here, we refer to the Woodlark Basin as the entire
F1. Regional tectonic setting of the Woodlark rift adjacent to the Papuan Peninsula, p. 28.

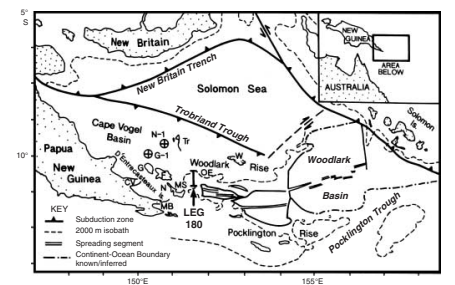

F2. Locations of sites drilled during Leg 180, p. 29.

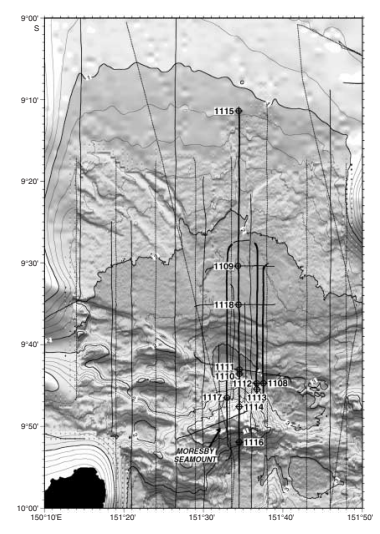


sedimentary system associated with the western Woodlark Basin, including the uplifted footwall to the south forming the Moresby Seamount, the deep rift basin, and the downflexed rift margin further north (Fig. F3).

Interpretation of sediment provenance within the Woodlark Basin must take into account a complicated regional tectonic setting (Davies et al., 1987; Honza et al., 1987; Lock et al., 1987). During Neogene time, calc-alkaline volcanoes were active within an arc that was mainly located to the south of the present Woodlark Basin in Papua New Guinea (Smith, 1982; Smith and Milsom, 1984). However, similar calc-alkaline volcanoes were located further north within the present forearc region (e.g., Woodlark Island) (Ashley and Flood, 1981). Papua New Guinea, an obvious potential source of terrigenous sediment in the Woodlark Basin, is geologically complex and includes Neogene arc volcanics, a Paleogene ophiolite, and underlying metamorphic rocks (Davies and Jaques, 1984).

\section{GEOLOGICAL HISTORY}

The oldest sediments recovered of middle to late Miocene age at the most northerly site (Site 1115) are mainly deep-water volcaniclastic turbidites related to the Miocene Trobriand arc (Fig. F4). This arc relates to southward subduction of oceanic crust of the Solomon Sea, located to the north (Honza et al., 1984; Davies et al., 1987). Seismic interpretation suggests that a forearc sedimentary wedge $\sim 5000 \mathrm{~m}$ thick, is present beneath part of the Woodlark Basin (Fig. F3). Drilling at Sites 1109 and 1118 terminated in diabase and basalt, either as massive rock (Site 1109) or as conglomerate (Site 1118). These lithologies probably originated as part of a Paleogene ophiolite (Taylor, Huchon, Klaus, et al., 1999; Robertson et al., 2001).

During the late Miocene, the forearc underwent regional emergence as also documented by industry wells to the northwest (Harris et al., 1985). At Site 1109, fluvial channelized? conglomerates, deposited in a nonmarine paralic setting, were overlain by lagoonal then open-marine carbonates. Similar conglomerates are abruptly overlain by open-marine carbonates with abundant coralline algae at Site 1118 further south. In the north, at Site 1115, 4-m, basalt-derived conglomerates with root traces are overlain by shallow-marine to lagoonal facies. The source of these conglomerates was possibly a then-emergent forearc to the southwest or west.

Paralic to inner neritic sediments appear at Sites 1109 and 1115 at approximately the same time $(>5.54$ and $<8.6 \mathrm{Ma})$. Shallow-water deposition was followed by Pliocene-Pleistocene deeper water hemipelagic and turbiditic deposition with discrete episodes of volcanic ash and volcaniclastic turbiditic input. In addition, the two sites (Sites 1114 and 1116) on the uplifted footwall (Moresby Seamount) document relatively proximal turbiditic and mass-flow deposition related to Pliocene rifting of the Trobriand forearc.

\section{MATERIALS AND METHODS}

During this study 21 samples of chemically analyzed fine-grained sediments were studied for mineral content by X-ray diffraction (XRD) using a Philips PW 1800 X-ray diffractometer system (Table T1). All of
F3. Interpretations of north-south seismic profiles, p. 30.

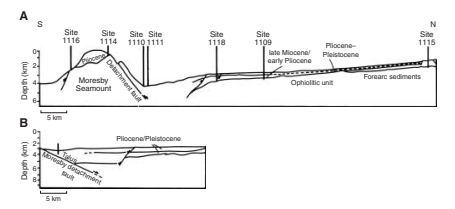

F4. Age-depth chart for the Leg 180 sites, p. 31.

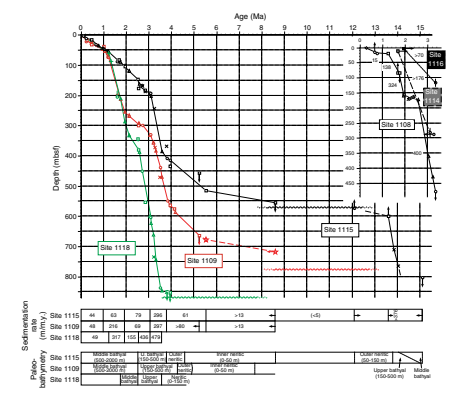

T1. XRD analysis of selected samples, p. 43. 
these samples were treated with glycol vapor, which aids identification of minerals with an expandable lattice (e.g., smectite). The samples were heated to $350^{\circ} \mathrm{C}$ initially and then $550^{\circ} \mathrm{C}$ to remove any smectite and kaolinite peaks. Earlier shipboard XRD analysis was restricted to interpretation of XRD traces of whole-rock samples and, thus, kaolinite was not then recognized. The heat treatment also confirmed the abundance of smectite in many samples.

In addition, 116 samples of fine-grained clay/claystone and silt/siltstone (mainly hemipelagic sediments) were analyzed for major elements and trace elements at the Department of Geology and Geophysics, University of Edinburgh, using a Philips PW 1480 wavedispersive automatic sequential X-ray fluorescence (XRF) spectrometer fitted with an Rh anode side-window X-ray tube. The sample preservation was as specified by Fitton et al. (1998). The elements Nb and several light rare earth elements (REEs) were reanalyzed using an improved high-precision technique involving extended count times. The complete data set is given (Tables T2, T3, T4, T5, T6, T7). Given the limited number of samples that could be analyzed, it was decided to focus on study of the two most complete successions recovered-Sites 1115 and 1109 on the inner and outer northern rift margins, respectively (Fig F2). Samples were analyzed at $\sim 10-\mathrm{m}$ intervals. In addition, a small number of samples were analyzed from the lower part of the succession recovered in the rift basin at Site 1118. Small suites of samples were also analyzed from the two sites on the Moresby Seamount (Sites 1114 and 1116).

The samples selected for XRF and XRD analysis were all relatively fine grained and homogeneous and thus representative of hemipelagic sedimentation at each drill site within the Woodlark Basin. Coarser grained sediments were avoided as were discrete layers of volcanic ash. The ashes are the subject of a separate geochemical study using an electron microprobe (Lackschewitz et al., 2001). In a separate study samples of undetermined grain size from which pore fluids were squeezed at sea ("squeeze cakes"), were later chemically and mineralogically analyzed to aid understanding of diagenetic processes affecting the Woodlark Basin sediments (see De Carlo et al., this volume).

In this paper, the sedimentary characteristics of the fine-grained sediments will first be summarized, based on smear slide analysis and shipboard XRD. The chemical results will then be discussed, highlighting implications for depositional processes and sediment provenance. Results from different sites will then be compared in the light of petrographic data on silts/siltstones and sands/sandstones (see Sharp and Robertson, this volume) and information on the volcanic ashes (see Lackschewitz et al., 2001). Geochemical studies of comparable sediments elsewhere are taken into account in the overall interpretation. The age model used is that of Takahashi et al. (this volume).

\section{CHEMICAL VARIATIONS AT INDIVIDUAL SITES}

Sediment composition is now considered on a site-by-site basis, working from north to south across the northern rift margin (Sites 1115 and 1109), followed by the rift basin (Site 1118), and then the southern rift margin (Site 1108). The sediments from the Moresby Seamount are considered last (Sites 1114 and 1116).
T2. XRF analysis of major and trace elements, Site 1115, p. 44.

T3. XRF analysis of major and trace elements, Site 1109, p. 47.

T4. XRF analysis of major and trace elements, Site 1118, p. 49.

T5. XRF analysis of major and trace elements, Site 1108, p. 51.

T6. XRF analysis of major and trace elements, Site 1114, p. 52.

T7. XRF analysis of major and trace elements, Site 1116 p. 53. 


\section{Northern Rift Margin: Site 1115}

Site 1115 is located on the northern rift margin (Fig. F2). This site spans the longest time interval of any drilled during Leg 180, from middle Miocene-Holocene time (Fig. F5). The oldest sediments form the uppermost part of a middle Miocene inferred forearc succession that shallows upwards and passes unconformably into a late Miocene nonmarine, fluvial to lagoonal succession. Latest Miocene-Pleistocene sediments record a shallow-marine succession that deepened progressively upwards into a dominantly clastic and hemipelagic succession that was deposited during subsidence of the Woodlark rift. Forty-seven samples were analyzed from this site (Table T2). Fine-grained hemipelagic sediments are present within most of the lithostratigraphic units recognized by the Shipboard Scientific Party, as outlined below:

\section{Lithostratigraphic Unit I}

Unit I of Pleistocene age (0-4.4 meters below seafloor [mbsf] in Hole 1115A and 0-35.7 mbsf in Hole 1115B) contains abundant nannofossil ooze, nannofossil silty clay, calcareous clay, and volcanic ash. The background pelagic sediment is dominated by nannofossils, planktonic foraminifers, radiolarians, and shell fragments. Mineralogy, as determined by shipboard XRD, is mainly calcite, quartz, and aragonite. Mainly siliceous volcanic glass is interpreted as primary air fall tuff. Shore-based XRD revealed abundant calcite, moderate amounts of quartz, and minor amounts of albite, aragonite, kaolinite, and pyrite (Table T1).

Three samples from Unit I were chemically analyzed (Table T2). The sample from the shallowest depth $(6.89 \mathrm{mbsf})$ is very calcareous $(42.41$ wt $\%)$, whereas another, from $17.03 \mathrm{mbsf}$, is only weakly calcareous (1.94 wt\% CaO). The major elements $\mathrm{Al}_{2} \mathrm{O}_{3}(<13.48 \mathrm{wt} \%), \mathrm{Na}_{2} \mathrm{O}(<5.24$ $\mathrm{wt} \%)$, and $\mathrm{K}_{2} \mathrm{O}(<3.97 \mathrm{wt} \%)$ exhibit relatively high values. Of the trace elements, the following show relatively elevated values: Th (11 ppm), $\mathrm{Ba}(538 \mathrm{ppm})$, and $\mathrm{Zr}(<546 \mathrm{ppm})$. In addition, $\mathrm{Nb}(<15 \mathrm{ppm})$, and REEs exhibit high values (i.e., Y $[<58 \mathrm{ppm}]$, Ce $[<92 \mathrm{ppm}]$, and $\mathrm{Nd}[<42$ $\mathrm{ppm}])$. Values include the highest recorded for these elements in the Woodlark Basin. By contrast, $\mathrm{Cu}, \mathrm{Ni}$, and $\mathrm{Cr}$ are relatively depleted.

A Ca-poor sample (from $17.05 \mathrm{mbsf}$ ) is interpreted as a volcanic ash. This sample is enriched in $\mathrm{Al}_{2} \mathrm{O}_{3}, \mathrm{Na}_{2} \mathrm{O}, \mathrm{K}_{2} \mathrm{O}$, Th, $\mathrm{Ba}, \mathrm{Zr}$, and REEs compared to the interbedded clayey sediments. By contrast, trace metals (i.e., $\mathrm{Cu}, \mathrm{Ni}$, and $\mathrm{Cr}$ ) are again relatively depleted. Unit I is inferred to contain volcanic ash of a distinctive high-K composition, correlated on the basis of electron microprobe studies, with high-K calc-alkaline volcanic rocks located in the Dawson Strait, Moresby Strait, or Dobu Seamount (Smith et al., 1977; Smith and Johnson, 1981; Stolz et al., 1993; Lackschewitz et al., 2001).

\section{Lithostratigraphic Unit II}

Unit II of late Pliocene-Pleistocene age (35-149 mbsf) exhibits a transition from mainly ooze to clay with less ash but relatively more volcaniclastic layers. Near the top, clay-rich sediments contain common bioclasts, foraminifers, nannofossils, pteropods, and scattered shell fragments. Smear slides exhibit quartz, feldspar, volcanic glass, nannofossils, foraminifers, and sponge spicules. Shipboard XRD revealed mainly calcite, quartz, and plagioclase. In addition, shore-based XRD revealed abundant calcite, moderate amounts of quartz, and minor
F5. Sedimentary succession on northern margin sites of the Woodlark rift, p. 32.

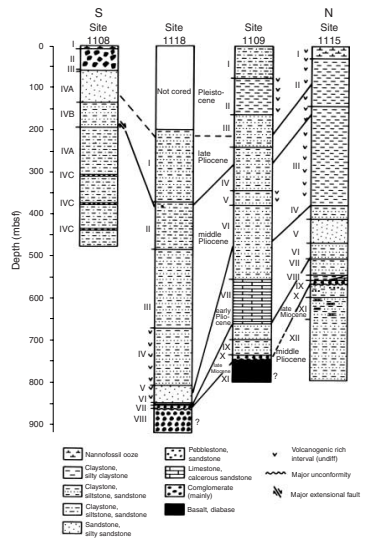




\section{A.H.F. RObERTSON AND T.R. SHARP}

amounts of aragonite, albite, pyrite, and kaolinite. One sample contains abundant albite (Table T1).

Eight samples were analyzed from Unit II. All are strongly calcareous ( $\mathrm{CaO} 27.40-35.48 \mathrm{wt} \%$; $\mathrm{Sr}<1688 \mathrm{ppm}$ ). $\mathrm{SiO}_{2}$ values are variable $(5.50-$ $10.67 \mathrm{wt} \%)$. MnO values are high but only relative to the low values in Unit I (to $2.68 \mathrm{wt} \%$ ). On the other hand, $\mathrm{K}_{2} \mathrm{O}$ and $\mathrm{Th}$ are low relative to Unit I. Values of $\mathrm{Ni}(<111 \mathrm{ppm}), \mathrm{Cr}(<144 \mathrm{ppm})$, and $\mathrm{Zr}(<265 \mathrm{ppm})$ are relatively high.

The above data are consistent with the presence of a calcareous volcanogenic mud composed of calc-alkaline volcanic rocks, in contrast to the high-K volcanic ash of Unit I.

\section{Lithostratigraphic Unit III}

Unit III, of early? to middle Pliocene age, extends from 149.7 to 293.1 mbsf in Hole 1115B and from 283.2 to 388.5 mbsf in Hole 1115C. This is the thickest single lithostratigraphic unit at Site $1115(240 \mathrm{~m})$ and is marked by the appearance of discrete thin graded beds of volcaniclastic sands within calcareous silty clay. $\mathrm{CaCO}_{3}$ values generally decrease from $>30 \mathrm{wt} \%$ to $\sim 20 \mathrm{wt} \%$ below $250 \mathrm{mbsf}$ (Taylor, Huchon, Klaus, et al., 1999). The physical composition of the clayey sediments is similar to Unit II. Smear slides revealed quartz, feldspar, mica, calcite, nannofossils, planktonic foraminifers, sponge spicules, and volcanic glass. Thin sections of impregnated clay-rich sediments confirmed the above composition, with the addition of plagioclase, hornblende, biotite, lithic fragments, and minor pyrite. Shipboard XRD revealed large amounts of calcite; also minor quartz, plagioclase, chlorite, and illite; rare ankerite, amphibole, and occasional dolomite. Carbonaceous debris appears lower in the unit. Shore-based XRD revealed abundant quartz, albite, and calcite, together with moderate amounts of phlogopite, tremolite, and pyrite.

Nineteen analyses were carried out on clayey sediments from Unit III. Compared with Unit II (see "Lithostratigraphic Unit II," p. 5), these sediments are less calcareous, whereas $\mathrm{SiO}_{2}, \mathrm{Al}_{2} \mathrm{O}_{3}$, and $\mathrm{TiO}_{2}$ are higher. Values of most metals and REEs are little changed from Unit III but, on average, slightly higher, commensurate with lower biogenic carbonate contents. Thus, the thick Unit II shows a similar, mainly volcanogenic, provenance to Unit III (i.e., basic to intermediate composition source volcanics) but with a reduced biogenic input.

\section{Lithostratigraphic Unit IV}

Unit IV is dominated by calcareous sandy silty claystone of early to middle? Pliocene age (388.5-417.30 mbsf). Observations of the cores suggested that the clayey sediments are poorly sorted and quite variable in grain size. Smear slides and shipboard XRD revealed similar compositions to Unit IV above. $\mathrm{CaCO}_{3}$ values are similar to those from the base of Unit III (Taylor, Huchon, Klaus, et al., 1999).

Two samples that were chemically analyzed from this unit show little significant difference from Unit I (see "Lithostratigraphic Unit I," p. 5). One of the main reasons for recognizing Unit V on the ship was its slightly coarser grain size with increased silt and sand compared to Unit IV. However, the fine-grained sediment composition remained unchanged between Units IV and V. 


\section{Lithostratigraphic Unit V}

Unit V (417.3-474.9 mbsf) is mainly sandstone of early to middle Pliocene age, in which only minor siltstone/claystone occurs, mainly in the upper parts of graded turbiditic sandstone. Smear slides exhibit quartz, plagioclase, biotite, rock fragments, volcanic glass, amphibole, bioclasts, and pyrite. Shipboard XRD revealed plagioclase and quartz, plus minor chlorite, illite, pyrite, amphibole, and aragonite. Samples were not chemically analyzed from this unit.

\section{Lithostratigraphic Unit VI}

Unit VI (479.9-513.4 mbsf) is mainly sandy siltstone to silty sandstone of latest Miocene to early Pliocene age. There is a decrease in grain size compared to Unit V. Little claystone is present. The finest grained sediment present is calcareous and clayey siltstone. Four samples analyzed from Unit VI are compositionally similar to the clayey sediments of Unit IV. However, several samples exhibit unusually high values of $\mathrm{Cr}(<304 \mathrm{ppm})$ and $\mathrm{Zr}(<229 \mathrm{ppm})$. These data suggest sediment input from mafic or ultramafic igneous sources (see "Discussion," p. 16).

\section{Lithostratigraphic Unit VII}

Unit VII (513.4-551.8 mbsf) is mainly siltstone of late Miocene age. Silty claystone makes up only a very minor component of the unit, which is mainly siltstone and sandstone. Smear slides revealed the presence of quartz, plagioclase, rare volcanic glass, amphibole, calcite, pyrite, rare nannofossils, and rare foraminifers. Shipboard XRD indicated the presence of plagioclase, calcite, quartz, illite, chlorite, aragonite, and pyrite. The abundance of shelly material points to a relatively shallow-water setting in common with Unit VI. Common plagioclase indicates locally abundant volcaniclastic input (see Sharp and Robertson, this volume). No samples were analyzed from Unit VII, as claystone is effectively absent.

\section{Lithostratigraphic Unit VIII}

Unit VIII (551.8-565.7 mbsf) comprises organic-rich silty claystone and bioclastic limestone of late Miocene age. The claystone is restricted to massive and finely laminated material, scattered particles, and discrete laminae of organic-rich sediment. In addition, greenish gray, less organic-rich claystone is present near the base of the unit. A single sample of the above greenish gray claystone was chemically analyzed (Table T2). This is relatively depleted in $\mathrm{CaO}(2.03 \mathrm{wt} \%), \mathrm{P}_{2} \mathrm{O}_{5}(0.032 \mathrm{wt} \%)$, and $\mathrm{Pb}$ but is relatively enriched in $\mathrm{TiO}_{2}$ (1.59 wt\%), $\mathrm{Cr}$ (924 ppm), $\mathrm{V}$ (284 ppm), and $\mathrm{Nd}$, and $\mathrm{Y}$. The laminae are thus interpreted as finegrained volcanogenic sediment.

\section{Lithostratigraphic Unit IX}

Unit IX (567.7-571.9 mbsf) is composed of sandstone, siltstone, and conglomerate of late Miocene age. Claystone is absent, and thus, no chemical analysis of this unit was carried out. The conglomerate and sandstone were mainly derived from basalt, now weathered. A littoral, 
beach, or fluvial setting was inferred (Taylor, Huchon, Klaus, et al., 1999; Robertson et al., 2001).

\section{Lithostratigraphic Unit X}

Unit X (579.9-603.85 mbsf) is sandstone, siltstone, claystone, and conglomerate of middle Miocene age. Shipboard XRD analysis of the finest grained sediment present, mainly siltstone, revealed the presence of pyroxene, amphibole, hematite, and illite. In addition, shore-based XRD analysis revealed abundant smectite and albite together with subordinate quartz, hematite, and calcite. In addition, minor abundances of the zeolite mineral, heulandite, probably reflects an input of volcanogenic material (Table T1).

Two samples analyzed from Unit $X$ reveal relatively high values of $\mathrm{MgO}$ (to $10.3 \mathrm{wt} \%), \mathrm{K}_{2} \mathrm{O}(<4.71 \mathrm{wt} \%), \mathrm{Cu}(<110 \mathrm{ppm}), \mathrm{Ni}(<207 \mathrm{ppm})$, and $\mathrm{Cr}(<505 \mathrm{ppm})$. These sediments are interpreted as mainly igneousderived but differ in composition from the volcanogenic muds of the overlying units. The relatively high $\mathrm{K}_{2} \mathrm{O}$ content could correlate with the occurrence of relatively K-rich volcanic glass in this interval (Lackschewitz et al., 2001), although the clay mineral, illite, is an additional potassium-rich source.

\section{Lithostratigraphic Unit XI}

Unit XI (603.85-657.8 mbsf) is mainly sandstone, carbonate packstone, siltstone, and silty claystone. This unit contains rare interbeds of massive and parallel-laminated silty claystone with sharp basal and upper contacts. The clay is locally organic rich. Associated siltstones are reddish colored and contain scattered planktonic foraminifers. One sample analyzed from this unit (619.96 mbsf) (Table T2) is very $\mathrm{MgO}$ rich (15.18 wt\%) but is otherwise similar to the claystones of Unit XI above, and is also of inferred mafic volcanogenic origin (i.e., $\mathrm{Ni}=423$ ppm and $\mathrm{Cr}=458 \mathrm{ppm}$ ).

\section{Lithostratigraphic Unit XII}

Unit XII (657.8-802.5 mbsf) is dominated by calcareous sandy siltstone and silty sandstone of middle Miocene age. The lower part of the unit includes silty claystones, first as laminae then as thin discrete beds. Smear slides reveal quartz, feldspar, sporadic biotite, pyroxene, rock fragments, calcite, and pyrite together with nannofossils, planktonic foraminifers, and rare sponge spicules. Shipboard XRD analysis revealed abundant plagioclase with subordinate calcite, quartz, pyroxene, smectite, and zeolite. In addition, shore-based XRD revealed abundant smectite, moderate amounts of quartz and albite, and minor calcite, kaolinite, and pyrite (Table T1). Petrographic study of the sandstones suggests a relatively basic calc-alkaline volcanic origin, probably from the now-submerged Trobriand forearc (see Sharp and Robertson, this volume). Four samples were chemically analyzed from Unit XII. These are compositionally quite constant and very similar to those of the overlying Units XI and X.

\section{Element Correlations}

Plots of $\mathrm{CaO}$ vs. $\mathrm{Al}_{2} \mathrm{O}_{3}, \mathrm{CaO}$ vs. $\mathrm{Fe}_{2} \mathrm{O}_{3}$, and $\mathrm{CaO}$ vs. $\mathrm{MgO}$ indicate inverse relations between $\mathrm{CaO}$ and the other three constituents (Fig. F6)
F6. Geochemical variation plots, Site 1115, p. 33.

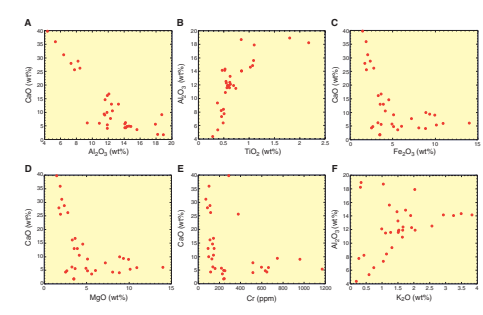


but only for higher values of $\mathrm{CaO}(>20 \mathrm{wt} \%)$. At $<20 \mathrm{wt} \% \mathrm{CaO}$, little correlation exists. High values of $\mathrm{K}_{2} \mathrm{O}(>2.5 \mathrm{wt} \%)$ occur in the uppermost sediments ( $<30 \mathrm{mbsf}$ ) and correspond to input of distinctive high$\mathrm{K}$ calc-alkaline volcanic ash. $\mathrm{Al}_{2} \mathrm{O}_{3}$, correlates positively with both $\mathrm{TiO}_{2}$ and $\mathrm{K}_{2} \mathrm{O}$. The high $\mathrm{MgO}$ and $\mathrm{Cr}$ values correspond to intervals (e.g., $\sim 600 \mathrm{mbsf}$ ) rich in material of calc-alkaline volcanic origin. In general, the more calcareous sediments have a high pelagic content, whereas those rich in $\mathrm{Al}_{2} \mathrm{O}_{3}, \mathrm{TiO}_{2}, \mathrm{~K}_{2} \mathrm{O}, \mathrm{Fe}_{2} \mathrm{O}_{3}, \mathrm{MgO}, \mathrm{Na}_{2} \mathrm{O}, \mathrm{Cr}$, and other heavy metals are mainly turbidites. The marked positive correlation of $\mathrm{Cr}$ and $\mathrm{Ni}$ indicates these elements are related, probably within minerals associated with ultramafic rocks or their alteration products. These could include $\mathrm{Cr}$ - or Ni-rich montmorillonite, Cr-rich pyroxene, serpentine minerals (e.g., crysotile), spinel, or magnetite (Deer et al., 1975).

Site 1115 differs from all the others analyzed in showing pronounced vertical trends (Fig. F7) that are correlated with a general upward increase in $\mathrm{CaO}$ values related to relatively increased biogenic pelagic carbonate content (Taylor, Huchon, Klaus, et al., 1999). $\mathrm{Al}_{2} \mathrm{O}_{3}, \mathrm{SiO}_{2}, \mathrm{Na}_{2} \mathrm{O}$, $\mathrm{Cr}$, and other constituents show inverse trends but with local variations (Fig. F7).

\section{Inner Rift Margin: Site 1109}

Site 1109 on the northern margin of the Woodlark rift (Fig. F2) penetrated a 773-m-thick succession floored by massive dolerite. Samples were chemically analyzed from 1.33 to 375.03 mbsf (Table T3).

\section{Lithostratigraphic Unit I}

The uppermost unit of middle-late Pliocene-Pleistocene age (0-9.50 mbsf in Hole 1109A; 0-14.80 mbsf in Hole 1109B; and 0-83.4 mbsf in Hole 1109C) is composed of calcareous silt, sand, and clay with volcaniclastic sand and volcanic ash. The calcareous clay is a major constituent of the lower part of the unit (Unit 1B), where it forms repeated intercalations up to several tens of meters thick. This lower interval contains several thin layers of volcanic ash (each $\sim 2 \mathrm{~cm}$ thick) together with greenish silt and rare volcaniclastic sands. The ash is interpreted as a primary pyroclastic deposit, possibly derived from volcanoes of the Trobriand arc or the Dawson Strait area (Taylor, Huchon, Klaus, et al., 1999; Lackschewitz et al., 2001). Only fine-grained nannofossil clays were analyzed in this study. However, the chemical composition of Unit I (six samples) is influenced by the presence of ash, as shown by smear slide analysis. Samples analyzed from Unit 1 are relatively rich in $\mathrm{CaO}$ $(<25.66 \mathrm{wt} \%)$ and $\mathrm{Sr}(<1552 \mathrm{ppm})$. Within this uppermost unit individual elements show no systematic downhole variation.

\section{Lithostratigraphic Unit II}

Unit II (84.40-169.70 mbsf) is defined by a marked change to greenish gray silt interbedded with abundant volcaniclastic sand. The presence of repeated normal-graded beds and other sedimentary structures is indicative of a turbiditic origin (Taylor, Huchon, Klaus, et al., 1999). Magnetic susceptibility is relatively high in this interval. Most of the silt and silty clay occurs in the upper part of graded beds, but some intervals of massive clay are also present, each up to several tens of centimeters thick. Shipboard XRD indicated the presence of calcite, chlorite, quartz, plagioclase, illite/muscovite, and amphibole. Ferromagnesian
F7. Variation in chemical composition vs. depth, Site 1115, p. 34 .

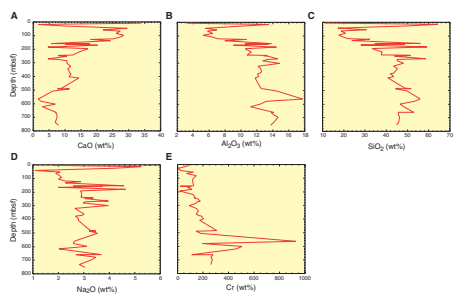




\section{A.H.F. ROBERTSON AND T.R. SHARP}

minerals (augite and amphibole) appear at the top of Unit II, together with clays of mixed-layer type. In addition, shore-based XRD revealed the presence in two samples of abundant albite and quartz and moderate amounts of talc, clinocrysotile (serpentinite), chlorite (Cr rich?), tremolite, and kaolinite (Table T1).

The major elements show a very marked drop in $\mathrm{CaO}$, from $26.2 \mathrm{wt} \%$ in the lowest sample of Unit II analyzed (80.83 mbsf), to $4.30 \mathrm{wt} \%$ in the uppermost sample of Unit II analyzed. There is a corresponding marked increase in $\mathrm{SiO}_{2}, \mathrm{Al}_{2} \mathrm{O}_{3}, \mathrm{Fe}_{2} \mathrm{O}_{3}, \mathrm{MgO}, \mathrm{Na}_{2} \mathrm{O}$, and $\mathrm{K}_{2} \mathrm{O}$. However, $\mathrm{TiO}_{2}$ shows no corresponding drop, which suggests that the clayey sediments of Unit I contain a relatively Ti-rich phase. Of the trace elements, there is a general increase in abundance up-section of $\mathrm{Ni}$ (to $741 \mathrm{ppm}$ ), $\mathrm{Cr}$ (to $1108 \mathrm{ppm}$ ), and $\mathrm{Zr}$ (to $382 \mathrm{ppm}$ ). Also, Th, $\mathrm{Pb}, \mathrm{Nb}, \mathrm{Rb}$, and $\mathrm{La}$ increase slightly, $\mathrm{Zn}, \mathrm{Cu}, \mathrm{Ce}$, and Y show little change, whereas $\mathrm{Sr}$ decreases.

\section{Lithostratigraphic Unit III}

Unit III (169.70-246.70 mbsf) is defined as clayey silts, and silty clay interbedded with clayey silt to coarse sand of middle to late Pliocene age. Greenish gray silty clay is the dominant sediment type in this unit. Smear slides reveal quartz, feldspar, volcanic glass, carbonate grains, planktonic foraminifers, nannofossils, radiolarians, and sponge spicules. The smear slides reveal a mixed lithogenic and biogenic composition. Shipboard XRD indicated the presence of mixed-layer clays. Shore-based XRD analysis of one sample confirmed the presence of abundant poorly crystalline material, possibly altered volcanic glass, together with moderate amounts of calcite, albite, and quartz but very little clay (Table T1).

Two samples of silty clay were chemically analyzed from Unit III. The chemical composition is similar to Unit II above; however, one sample exhibits higher values of trace elements and REEs (Table T3).

\section{Lithostratigraphic Unit IV}

Unit IV of middle to late Pliocene age (246.7-362.2 mbsf) is composed of relatively uniform greenish clayey siltstone and silty claystone with scattered planktic foraminifers and rare volcanic ash layers. Shipboard XRD indicated the presence of common calcite, plagioclase, and quartz with variable amounts of chlorite, illite, augite and amphibole. Smear slides reveal mixed lithogenous and biogenic material as in Unit III, however, volcanic glass is relatively sparse. $\mathrm{CaCO}_{3}$ values range from 8.7-39 wt\% (Taylor, Huchon, Klaus, et al.; 1999).

Three samples were analyzed from Unit IV. These show a marked increase in $\mathrm{CaO}(<16.80 \mathrm{wt} \%)$ and $\mathrm{Sr}(<1793 \mathrm{ppm})$ but a decrease in $\mathrm{Ni}$, $\mathrm{Cr}$, and $\mathrm{Zr}$ relative to samples analyzed from Unit III.

\section{Lithostratigraphic Unit V}

Unit V (352.8-387.6 mbsf in Hole 1109D) is made up of silty claystone interbedded with volcaniclastic layers and is of middle Pliocene age. Shipboard XRD revealed calcite, plagioclase, quartz, illite, chlorite, amphibole, augite, smectite, and rare alkali feldspar. Three samples analyzed exhibit near-average values for the site as whole with no unusual abundances. 


\section{Lithostratigraphic Unit VI}

Unit VI (387.6-570.4 mbsf) is clayey siltstone and silty claystone interlayered with silty claystone to coarse sandstone and is of early Pliocene-middle Pliocene age. Shipboard XRD of the claystone revealed calcite, plagioclase, and quartz together with subordinate amphibole and rare pyroxene. Illite/muscovite is the dominant clay mineral with variable amounts of chlorite and rare smectite. One sample contains potassium feldspar, and aragonite is locally present. Shore-based study revealed abundant calcite, albite, and quartz, together with moderate amounts of smectite and pyrite (Table T1). Of two samples analyzed chemically, one of these is unusual as it exhibits high values of $\mathrm{Cr}$ (241 ppm), Ce (56 ppm), Zr (255 ppm), La (30 ppm), Ce (66 ppm), and Nd (32 ppm). Shore-based XRD study of this sample revealed albite, quartz, smectite, and kaolinite.

\section{Lithostratigraphic Unit VII}

Unit VII (570.4-671.8 mbsf) is heterogeneous sandstone, packstone, and grainstone. No samples were chemically analyzed, as fine-grained argillites are effectively absent. Beneath this, Unit VIII (671.8-705.3 mbsf) comprises poorly dated silty claystone and clayey siltstone. Claystones are restricted to thin $(<3 \mathrm{~mm})$ local anastomosing laminae rich in dark carbonaceous material. These were not chemically analyzed. Below this, no samples from Unit VIII were analyzed, as claystones are absent.

\section{Lithostratigraphic Unit IX}

Unit IX (705.3-737.2 mbsf), near the base of the sedimentary succession, is dominated by clayey siltstone and sandstone above a basement of dolerite. Vaguely mottled blue-green silty claystone is common near the base of the unit. Associated clay-rich siltstone contains quartz, feldspar, biotite, clay, volcanic rock fragments, accessory minerals, and minor inorganic calcite, as indicated by shipboard smear slide analysis. XRD analysis further indicates that smectite is abundant. Also, small red goethite concretions and rare carbonate concretions were observed in the cores and thin sections Sharp and Robertson (this volume). This unit is interpreted to have accumulated in a coastal swamplike setting under tropical weathering conditions (Taylor, Huchon, Klaus, et al., 1999; Robertson et al., 2001).

\section{Lithostratigraphic Unit $\mathbf{X}$}

Unit X (737.2-772.9 mbsf) comprises an igneous-derived conglomerate mainly composed of clasts of variolitic basalt and dolerite, the latter containing altered plagioclase, olivine, or augite. There is also minor interstitial claystone and siltstone. Shore-based XRD study of one sample revealed abundant smectite and moderate amounts of albite and quartz (Table T1). Two samples from Unit $\mathrm{X}$ are unusually rich in $\mathrm{Al}_{2} \mathrm{O}_{3}(18.22$ $\mathrm{wt} \%$ and $18.83 \mathrm{wt} \%), \mathrm{Fe}_{2} \mathrm{O}_{3}(15.64 \mathrm{wt} \%$ and $16.47 \mathrm{wt} \%)$, and $\mathrm{TiO}_{2}(1.80$ wt $\%$ and $2.17 \mathrm{wt} \%)$ but are low in $\mathrm{CaO}(1.78 \mathrm{wt} \%$ and $1.92 \mathrm{wt} \%) . \mathrm{K}_{2} \mathrm{O}$ (0.340 wt $\%$ and $0.325 \mathrm{wt} \%)$, and $\mathrm{P}_{2} \mathrm{O}_{5}(0.105 \mathrm{wt} \%$ and $0.094 \mathrm{wt} \%)$. Of the trace elements and REEs, Zn (108-113 ppm), V (to $425 \mathrm{ppm}$ ), and $\mathrm{Y}$ (31-34 ppm) are relatively high, whereas $\mathrm{Sr}$ is low (239-229 ppm) as is $\mathrm{Rb}$ (5 ppm). Beneath, the well terminated in massive dolerite. 


\section{Element Correlations}

Site 1109 shows similar correlations to Site 1115 further north. $\mathrm{Al}_{2} \mathrm{O}_{3}$ vs. $\mathrm{CaO}$, and $\mathrm{Al}_{2} \mathrm{O}_{3}$ vs. $\mathrm{K}_{2} \mathrm{O}$ show inverse correlations (Fig. F8). A positive correlation of $\mathrm{Cr}$ and $\mathrm{Ni}$ points to an association of specific mineral phases (e.g., pyroxene, or amphibole) in volcanogenic turbidites.

\section{Rift Basin: Site 1118}

Site 1118 is located towards the northern margin of the Woodlark rift basin, $9 \mathrm{~km}$ south of Site 1109, and was positioned to determine the nature of the rift succession and underlying "basement" (Fig. F2). Owing to a shortage of time at the end of the leg, the site was washed down to 205 mbsf and then drilled into the "basement." The upper part of the cored succession, of late Pliocene-Pleistocene age, comprises volcaniclastic sandstones and siltstones of turbiditic origin interbedded with claystones and minor volcanic ash. Beneath this, the lower part of the succession contains abundant terrestrial material including woody debris. The succession passes downwards into early Pliocene limestones, calcareous paraconglomerates, and volcaniclastic sandstone deposited in a marine lagoon rich in calcareous algae. The well bottomed in nonmarine conglomerate mainly composed of diabase and minor basalt with paleosol intercalations (Taylor, Huchon, Klaus, et al., 1999).

\section{Lithostratigraphic Unit I}

The uppermost unit cored, from 205.0 to $377.8 \mathrm{mbsf}$, is composed of siltstones, claystones, and graded sandstones of late Pliocene-Pleistocene age. The background sediment is greenish gray silty claystone and clayey siltstone. A number of distinctive horizons of reddish silty claystone exist. Smear slides of the claystone exhibit common nannofossils and planktonic foraminifers, feldspar, biotite, volcanic glass, hornblende, and inorganic calcite. Shipboard XRD identified the presence of plagioclase, calcite, pyroxene, minor amphibole, illite, and smectite and possible mixed-layer clays. Dolomite and chorite occur occasionally. Below $290 \mathrm{mbsf}$, calcite, plagioclase, and quartz predominate with minor clay minerals (e.g., chlorite). Unit I is comparable to sediments of the same age at Site 1109, and for this reason samples were not chemically analyzed.

\section{Lithostratigraphic Unit II}

Unit II extends from 377.8 to 492.35 mbsf and comprises reddish claystones, siltstones greenish gray siltstones, and sandstones of middle Pliocene to late Pliocene age. Both smear slide and XRD studies reveal very similar compositions to Unit I. Chemical analyses of this unit were not made either.

\section{Lithostratigraphic Unit III}

Unit III, from 492.35 to 679.27 mbsf, consists of sandstones, siltstones, and fine-grained sediments of middle Pliocene age. The background sediment comprises silty claystone and clayey siltstone. Smear slides indicate little change in composition from above. There are also sporadic thin layers of pale volcanic ash. Shipboard XRD indicated a very constant composition dominated by calcite, plagioclase, and
F8. Geochemical variation plots, Site 1109, p. 35.

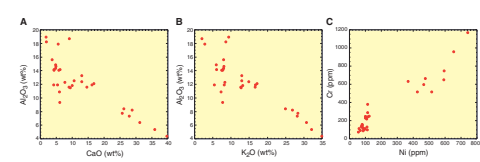


quartz with minor amphibole, pyroxene, chlorite, illite, smectite, and pyrite. In addition, shore-based XRD analysis revealed abundant calcite and quartz, moderate amounts of albite and smectite, and minor amounts of kaolinite (Table T1).

Eleven samples of fine-grained sediment were chemically analyzed from Unit III (Table T4). The content of major elements, trace elements, and REEs is remarkably constant, more than in any other unit of equivalent thickness in the Woodlark Basin. Of the major elements, only $\mathrm{CaO}$ shows significant variation (from 5.90 to $18.03 \mathrm{wt} \%$ ). Trace metals exhibit moderately high values $(\mathrm{Ni}=<113 ; \mathrm{Cr}=<262$; and $\mathrm{Zr}=<62$ $\mathrm{ppm}$ ). Some of the interbedded sandstones include abundant grains derived from mafic igneous rock. Volcanic ash layers in Unit III were not analyzed.

\section{Lithostratigraphic Unit IV}

Unit IV, from 679.27 to $810.84 \mathrm{mbsf}$, is made up of silty claystone, clayey siltstone, graded sandstone, and siltstone turbidites of middle Pliocene age. Overall, the unit is coarser grained than the overlying sedimentary succession. The fine-grained sediments differ from those in the units above, as they commonly contain mixtures of detrital volcanic grains and volcanic ash. There are also numerous thin pale layers rich in silicic volcanic glass. In addition to pyroclastic ash, detrital volcanic grains present are plagioclase, quartz, biotite, hornblende, and lithoclasts of basic and acid extrusive rocks.

Six samples that were chemically analyzed (Table T4) do not differ in any perceptible way from the fine-grained sediments of Unit III. These samples did not include discrete volcanic ash layers, although the background sediments are clearly rich in dispersed volcanic ash.

\section{Lithostratigraphic Unit V}

Unit $\mathrm{V}$, from 810 to $857.1 \mathrm{mbsf}$, is made up of mixed sandstone, siltstone, and volcaniclastic sandstone of middle Pliocene-latest early Pliocene age at the base. Intercalated claystones are admixed with scattered volcaniclastic grains and organic matter. Pyrite is occasionally present. Shore-based XRD revealed abundant quartz and smectite, moderate amounts of albite and calcite, minor amounts of kaolinite, tremolite, muscovite or illite and pyrite (Table T1). Four samples that were chemically analyzed are similar to the finer grained sediments higher in the succession. Several samples are relatively rich in trace metals $(\mathrm{Ni}=$ 106; $\mathrm{Cr}=227 \mathrm{ppm}$; and $\mathrm{Zr}=147 \mathrm{ppm}$ ).

\section{Lithostratigraphic Unit VI}

Unit VI, from 857.1 to $859.0 \mathrm{mbsf}$, is a packstone and grainstone (limestone) of early Pliocene or older. Clays are absent, and thus, no samples were chemically analyzed from this interval.

\section{Lithostratigraphic Unit VII}

Unit VII, from 859.00 to 873.1 mbsf, consists of undated paraconglomerate composed of basalt and diabase clasts in a matrix of bioclastic debris. One clay-rich sample from near the base of the unit contains $3.84 \mathrm{wt} \% \mathrm{~K}_{2} \mathrm{O}$. Of the trace elements and REEs, $\mathrm{V}$ and $\mathrm{Y}$ are relatively 
enriched, whereas $\mathrm{Ba}, \mathrm{Ce}, \mathrm{Pb}$, and $\mathrm{Rb}$, are depleted compared to the overlying fine-grained sediments, above.

\section{Lithostratigraphic Unit VIII}

Finally, Unit VIII, from 873.1 to $929.6 \mathrm{mbsf}$, of unknown age, is dominated by weathered conglomerate with clasts composed of dolerite and diabase with interbedded mainly reddish paleosols. A single sample of palaeosol was analyzed from 900.75 mbsf. This exhibits high $\mathrm{Fe}_{2} \mathrm{O}_{3}$ and $\mathrm{TiO}_{2}$ but low $\mathrm{K}_{2} \mathrm{O}$.

\section{Element Correlations}

The expanded rapidly deposited Pliocene interval cored at Site 1118 (Fig. F4) ideally illustrates interelement relationships (Fig. F9). $\mathrm{Al}_{2} \mathrm{O}_{3}$ shows a positive correlation with $\mathrm{Na}_{2} \mathrm{O}, \mathrm{K}_{2} \mathrm{O}$, and $\mathrm{SiO}_{2}$ and a less distinct correlation with $\mathrm{TiO}_{2}$. The $\mathrm{Al} / \mathrm{Na}$ relationship is attributed to the abundance of plagioclase feldspar, mainly albite. The $\mathrm{Al} / \mathrm{K}$ correlation probably relates to the presence of clay minerals (illite and smectite). The two relatively Ti-rich, but $\mathrm{K}_{2} \mathrm{O}$-poor samples were derived from low$\mathrm{K}$ tholeite of probable ophiolitic origin (see "Discussion," p. 16). The $\mathrm{Al}_{2} \mathrm{O}_{3} / \mathrm{SiO}_{2}$ relationship reflects the input of aluminosilicates (e.g., feldspar and clay minerals). The sole markedly anomalous sample with $>60$ $\mathrm{wt} \% \mathrm{SiO}_{2}$ is attributed to the presence of siliceous volcanic glass, as detected in smear slides from this interval (i.e., $767.03 \mathrm{mbsf}$ ) and confirmed by electron microprobe analysis (Lackschewitz et al., 2001). $\mathrm{Al}_{2} \mathrm{O}_{3}$ shows strong correlation with $\mathrm{Zr}$, possibly corresponding to the occurrence of zircon of continental origin. $\mathrm{Al}_{2} \mathrm{O}_{3}$ shows a slight positive correlation with $\mathrm{Y}$ but none with $\mathrm{MgO}$ or $\mathrm{Cr}$ (not shown). $\mathrm{MgO}$ shows a weak positive correlation with $\mathrm{Cr}, \mathrm{Ni}, \mathrm{Cu}$, and $\mathrm{Zn}$, reflecting the common occurrence of minerals inferred to have been derived from mainly ultramafic rocks. $\mathrm{Fe}_{2} \mathrm{O}_{3}$ remains relatively constant compared to $\mathrm{MnO}$. Relatively high values appear sporadically within the succession but are mainly within the range of composition of hemipelagic clay in general (Turekian and Wedepohl, 1961; Gromet et al., 1984). The unusually high $\mathrm{Fe}_{2} \mathrm{O}_{3}$ values are from altered material associated with basic igneous rock (conglomerate) near the base of the succession drilled. $\mathrm{Cr}$ and $\mathrm{Ni}$ are again positively correlated as at other sites. Several other typical correlations are apparent, notably $\mathrm{Fe}_{2} \mathrm{O}_{3}$ with $\mathrm{Y}$ and $\mathrm{CaO}$ with Sr. Ba also shows a negative correlation with $\mathrm{MnO}$.

\section{Proximal Hanging Wall of the Rift: Site 1108}

Site 1108 is located near the base of the northern slope of the Moresby Seamount (Fig. F2) and was positioned with a view to penetrating the extensional detachment fault defining the southern margin of the Woodlark rift. The upper part of the succession (Units I-III) comprises superficial calcareous hemipelagic sediments underlain by a breccia composed of heterogeneous clasts (Fig. F5), inferred to have come from upslope on the Moresby Seamount (Robertson et al., 2001). During this study, samples of fine-grained sediments were chemically analyzed only from Unit IV, a succession of middle-late Pliocene hemipelagic clayey sediments and gravity-deposited clastic sediments, interpreted mainly as classical turbidites and high-density turbidites. Details of the depth ranges are given in Taylor, Huchon, Klaus, et al. (1999).
F9. Geochemical variation plots, Site 1118 , p. 36.

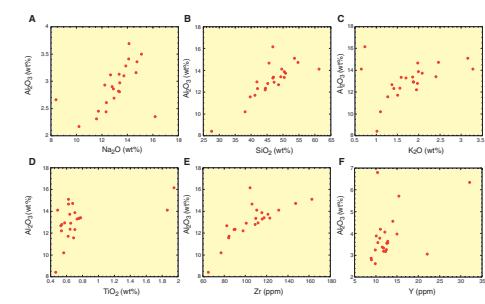




\section{Lithostratigraphic Subunit IVA}

Subunit IVA is dark greenish gray claystones interbedded with dark gray graded coarse- to medium-grained sandstones and siltstones interbedded with minor pebblestones. Shore-based XRD analysis revealed abundant quartz, and albite, moderate amounts of smectite, kaolinite, and calcite, and minor amounts of muscovite, or illite and pyrite (Table T1). A sample from low in the succession contains abundant smectite. Subunit IVB is a mainly finer grained interval of greenish gray to dark greenish gray foraminifer-bearing clayey siltstones interbedded with fine-grained sandstone. Bioturbation occurs throughout. Occasional coarser grained pebblestones were defined as Subunit IVC.

Seven claystone samples were analyzed from Unit IV (Subunits A and B) (Table T5). Of the major elements, $\mathrm{SiO}_{2}$ varies over a narrow range (42.8-53.71 wt\%), as do $\mathrm{Al}_{2} \mathrm{O}_{3}$ (12.31-17.3 wt\%), $\mathrm{MgO}, \mathrm{CaO}, \mathrm{Na}_{2} \mathrm{O}$, $\mathrm{K}_{2} \mathrm{O}, \mathrm{TiO}_{2}, \mathrm{MnO}$, and $\mathrm{P}_{2} \mathrm{O}_{5}$. One sample is unusually calcareous (14.81 $\mathrm{wt} \%)$. This sample is also relatively rich in $\mathrm{MnO}(0.25 \mathrm{wt} \%)$ and $\mathrm{P}_{2} \mathrm{O}_{5}$ $(1.28 \mathrm{wt} \%)$. Three of the other samples contain $>10 \mathrm{wt} \% \mathrm{Fe}_{2} \mathrm{O}_{3}$. Of the trace elements, the following elements are relatively abundant $(\mathrm{Zr}=97$ 232; $\mathrm{Cu}=53-130 ; \mathrm{Ni}=9-297$; and $\mathrm{Cr}=197-309 \mathrm{ppm})$. None of the elements exhibit any systematic downhole variation, which is not surprising given the small number of samples analyzed.

\section{Element Correlations}

$\mathrm{Al}_{2} \mathrm{O}_{3}$ shows a clear positive correlation with $\mathrm{K}_{2} \mathrm{O}$ and to a lesser extent with $\mathrm{Na}_{2} \mathrm{O}$, presumably mainly related to clay mineral and feldpsar content (Fig. F10). By contrast, no correlation is evident between $\mathrm{Al}_{2} \mathrm{O}_{3}$, and either $\mathrm{TiO}_{2}$ or $\mathrm{MgO}$ (not shown). However, $\mathrm{MgO}$ correlates with both $\mathrm{Ni}$ and $\mathrm{Cu}$; also $\mathrm{Ni}$ and $\mathrm{Cu}$ correlate positively. The probable source of these elements is from ultramafic rock or their erosion products (see "Discussion," p. 16).

\section{Northern Margin of the Moresby Seamount: Site 1114}

Site 1114 is located close to the northeastern edge of the Moresby Seamount (Fig. F2). Beneath thin superficial unconsolidated Pleistocene hemipelagic sediments, a several-hundred-m-thick succession of more consolidated hemipelagic sediments (Unit II and Subunit IIIA), subordinate sandstones (Unit IV), and conglomerates (Subunit IIIB) were recovered, all of Pliocene age (Fig. F11). At the base of the sedimentary succession, a tectonic breccia $5 \mathrm{~m}$ thick was penetrated before the well bottomed in metadiabase. The sediments recovered are dominated by volcaniclastic turbidites, interbedded with mudstones and siltstones. Coarse-grained sandstones predominate in the lower part of the succession, whereas finer grained sandstones, siltstones, and claystones dominate higher up. These sediments accumulated from suspension or by gravity deposition and include intervals interpreted as high-density turbidity current deposits (Taylor, Huchon, Klaus, et al., 1999; Robertson et al., 2001).

Six samples from Units III (55.0-237.6 mbsf) and IV (237.6-276.1 mbsf) were chemically analyzed, ranging from 65.14 to $237.76 \mathrm{mbsf}$ (Table T6). Within Unit III, subordinate weakly lithified dark gray claystone is interbedded with sandstones and siltstones. Smear slides of claystone reveal quartz, plagioclase, biotite, clay, rare small volcanic
F10. Geochemical variation plots, Site 1108, p. 39.

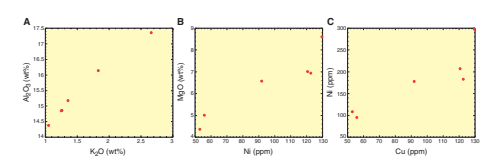

F11. Sedimentary succession drilled on the southern margin of the Woodlark rift, p. 40.

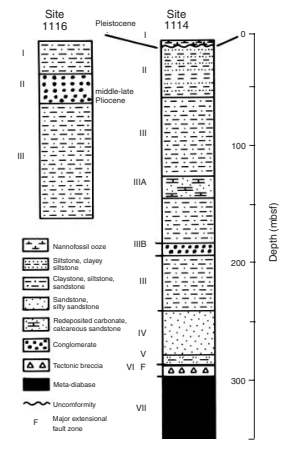


rock fragments, volcanic glass, pyrite, inorganic calcite, accessory minerals, poorly preserved nannofossils, and rare planktonic foraminifers. Shipboard XRD analysis revealed quartz and plagioclase with variable amounts of calcite, amphibole, pyroxene, and illite. Shore-based XRD indicated the presence of abundant quartz, and albite; also moderate amounts of calcite, smectite, and kaolinite; and locally minor pyrite (Table T1).

Of the samples analyzed, one in the upper part of Unit IIIA is strongly calcareous $(39.73 \mathrm{wt} \%)$. The remaining samples are relatively rich in $\mathrm{TiO}_{2}$ (up to $1.02 \mathrm{wt} \%$ ), $\mathrm{Cu}$ (to $161 \mathrm{ppm}$ ), $\mathrm{Ni}$ (to $125 \mathrm{ppm}$ ), and $\mathrm{Cr}$ (to $251 \mathrm{ppm}$ ), $\mathrm{V}$ (to $273 \mathrm{ppm}$ ), and $\mathrm{Ba}$ (469 ppm).

\section{Element Correlations}

The few samples analyzed show little signs of positive correlations of $\mathrm{Al}_{2} \mathrm{O}_{3}$ (e.g., with $\mathrm{K}_{2} \mathrm{O}$, and $\mathrm{Na}_{2} \mathrm{O}$ ), in contrast to the sites discussed earlier. However, positive correlations are still apparent between $\mathrm{MgO}$ and $\mathrm{Ni}, \mathrm{Cu}$ and $\mathrm{Cr}$, suggesting the presence of an ultramafic source, as discussed further below.

\section{Southern Margin of the Moresby Seamount: Site 1116}

Site 1116 is located near the southern edge of the Moresby Seamount (Fig. F2). The sedimentary succession (Fig. F11) is mainly Pliocene claystone, siltstone, and sandstone (Units I and III) with a conglomerate intercalation (Unit II). As at Site 1114, the succession is interpreted as mainly hemipelagic claystones and mudstones intercalated with turbidity current deposits, including some that accumulated from highdensity turbidity currents (Taylor, Huchon, Klaus, et al., 1999; Robertson et al., 2001). Shipboard XRD study of Units I (0.0-33.8 mbsf) and III (62.5-158.9 mbsf) confirmed the presence of quartz, plagioclase, and subordinate calcite, chlorite, illite, smectite, amphibole, and pyroxene. Shore-based study indicated the presence of abundant albite and smectite, moderate amounts of calcite and quartz, and minor pyrite (Table T1).

Six samples of hemipelagic sedimentary rocks were chemically analyzed (Table T7), two from Unit I and four from Unit III. Major element oxides show little variation other than for $\mathrm{Fe}_{2} \mathrm{O}_{3}$ (6.97-12.13 wt\%). Some trace elements and REEs exhibit relatively high values $(\mathrm{Zr}=<103$; $\mathrm{Cu}=<172 ; \mathrm{Ni}=<126 ; \mathrm{Cr}=<224 ; \mathrm{Ba}=<369 ; \mathrm{Zn}=<247 ;$ and $\mathrm{Ce}=<68$ $\mathrm{ppm})$. These fine-grained sediments are again mainly volcanogenic muds rich in ferromagnesian minerals from calc-alkaline or ultramafic sources. Few interelement correlations are apparent on scatter plots.

\section{DISCUSSION}

The mid-late Miocene forearc sediments exposed at Site 1109 are characterized by relatively high values of $\mathrm{MgO}, \mathrm{K}_{2} \mathrm{O}, \mathrm{Cu}, \mathrm{Ni}$, and $\mathrm{Cr}$ and are interpreted as having been derived from mafic volcanic arc rocks (e.g., basaltic andesites). However, ultramafic rocks could be an additional source if the Papuan ophiolite was then exposed to erosion within the sediment catchment area. Petrographic evidence revealed pyroxene and other ferromagnesian grains interpreted as eroded from a poorly lithified Miocene arc-related unit (see Sharp and Robertson, this volume). 
The sediments above the massive dolerite (Site 1109) are relatively enriched in $\mathrm{TiO}_{2}(2.17 \mathrm{wt} \%$ at $745 \mathrm{mbsf})$. This could reflect the existence of a relatively Ti-rich igneous basement interpreted as a Paleogene ophiolite. This contrasts with the low-Ti calc-alkaline compositions higher in the succession. In addition, strong enrichment in $\mathrm{Fe}_{2} \mathrm{O}_{3}$ is attributed to an abundance of strongly oxidized detrital material, as confirmed by petrographic study of siltstones and sandstones (see Sharp and Robertson, this volume).

Site 1115 in the north is exceptional in that there is a progressive upward increase in $\mathrm{CaO}$ (Fig. F7) and $\mathrm{CaCO}_{3}$ (Taylor, Huchon, Klaus, et al., 1999). This trend is mirrored by a corresponding decrease in most other major elements, some minor trace elements, and REEs. However, $\mathrm{Cu}$, $\mathrm{Ni}, \mathrm{Cr}$ and $\mathrm{Zr}$ exhibit an unrelated "spiky" pattern (e.g., at $560 \mathrm{mbsf}$ ). The upward increase in carbonate is attributed to relatively increased biogenic carbonate input. This site on the northern flank of the Woodlark rift was relatively isolated from input of terrigenous sediment from Papua New Guinea, the Entrecasteaux Islands, the Cape Vogel Basin, and adjacent areas that were then still emergent.

Further south on the inner rift flank at Site 1109 there are no systematic vertical trends in the bulk chemical composition. However, sediments are much more calcareous above 90.3 mbsf (Unit I) correlating with relatively increased pelagic carbonate and reduced sedimentation rate (Fig. F4). Vertical trends are erratic, with absolute abundances of $\mathrm{MgO}, \mathrm{Cr}$, and Ni reaching their highest recorded levels in the Woodlark Basin. These "spikes" might reflect ferromagnesian mineral abundance (Cr-rich pyroxene or $\mathrm{Cr}$ olivine). However, strong $\mathrm{Cr}$ and $\mathrm{Ni}$ enrichment is not typical of normal volcanic-arc extrusive rocks as indicated by electron microprobe analysis of associated volcanic glass (Lackschewitz et al., 2001). A more probable source is from ultramafic rocks (e.g., peridotite) or their alteration products.

What then was the source of these chemically unusual sediments? Site 1109 is located on the northern rift margin, an area that is today relatively isolated from input of ultramafic detritus from the Papuan landmass. Ophiolites may also be present beneath the forearc to the north (e.g.,Woodlark Island) (Ashley and Flood, 1981) but are unlikely to have contributed much sediment to the Woodlark rift further south, as this area was largely covered with marine sediments during PlioceneQuaternary time. Site 1109 is positioned near a modern submarine channel, which in the past may have acted as a conduit for gravity redeposition of volcaniclastic sediment derived from calc-alkaline volcanoes on Trobriand Island and adjacent areas (Robertson et al., 2001). This could readily explain the abundance of volcaniclastic sands rich in ferromagnesian minerals (pyroxene, and amphibole) (see Sharp and Robertson, this volume) but does not by itself explain the locally very high $\mathrm{Cr}$ and $\mathrm{Ni}$ values. High values of these heavy metals also occur sporadically further north at the rift shoulder site (Site 1115). Instead, ultramafic rocks or their erosion products, were the probable source, as confirmed by XRD identification of local talc and crysotile at Site 1109.

How then could ultramafic erosion products reach Sites 1109 and 1115 north of the deep Woodlark rift? Low-density turbidity currents possibly flowed upslope to reach Site 1109, but transport to the more northerly rift shoulder site (Site 1115) is problematic assuming the present bathymetry. Alternatively, the present deep Woodlark rift basin did not then act as a barrier to wider turbiditic dispersal of fine-grained sediment. In this scenario, fine-grained sediments accumulated in all 
parts of the present Woodlark Basin during late Miocene-late Pliocene time but this was followed by rifting and subsidence to create the deep Woodlark rift basin (Sites 1108 and 1118), Moresby Seamount (uplifted footwall), and the upflexed northern margin of the rift (Sites 1109 and 1115). Terrigenous sediments ceased to reach these northern rift margin sites during Pleistocene time.

At both Sites 1109 and 1115, the mainly Pleistocene upper parts of the successions $(<2.3 \mathrm{Ma})$ are strongly calcareous and exhibit relatively high $\mathrm{K}_{2} \mathrm{O}$ but depletion in $\mathrm{MgO}$ and trace metals (e.g. $\mathrm{Cr}$ and $\mathrm{Ni}$ ). A continental source is unlikely in view of the abundance of volcanic glass (shown by shipboard smear slide analysis) and the paucity of clay minerals. Input from a distinctive potassic volcanic source is instead preferred, as confirmed by electron microprobe studies of volcanic glasses (Lackschewitz et al., 2001). The probable source is Dawson Strait, Moresby Strait, or Dobu Seamount. Recovery from the lower part of the Woodlark rift succession at Site 1118 exhibits a sediment composition that is similar to the lower, less calcareous Pliocene part of the succession at Site 1108. Occasional horizons are unusually rich in $\mathrm{K}_{2} \mathrm{O}$, which may correlate with occurrence of illite or muscovite. High $\mathrm{K}_{2} \mathrm{O}$ records either an unusual volcanic composition or a continental input. The latter is favored in view of the petrographic evidence of abundant silt to sand-sized metamorphic detritus (e.g. schist, gneiss, and muscovite) (see Sharp and Robertson, this volume). However, the $\mathrm{K}_{2} \mathrm{O}$-rich intervals also exhibit high values of $\mathrm{MgO}, \mathrm{Cr}, \mathrm{Ni}$ and $\mathrm{Cu}$, in turn, suggesting that the terrigenous and mafic or ultramafic igneous-derived sediments are well mixed with no evidence of separate sediment sources or compositionally differing sediment pathways.

Site 1108, on the proximal rift hanging wall, exhibits relatively high $\mathrm{Fe}_{2} \mathrm{O}_{3}$ (to $11.43 \mathrm{wt} \%$ ), $\mathrm{MgO}, \mathrm{TiO}_{2}$ (to $1.06 \mathrm{wt} \%$ ), $\mathrm{MgO}, \mathrm{P}_{2} \mathrm{O}_{5}, \mathrm{Cu}, \mathrm{Ni}$, and $\mathrm{Cr}$. The composition is similar to that at 1109 on the northern rift flank, reflecting input from a calc-alkaline volcanic source. By contrast, the occasional occurrence of relatively high $\mathrm{TiO}_{2}(<1.02 \mathrm{wt} \%)$ is suggestive of an additional undepleted igneous source, possibly related to Paleogene ophiolite magnetically related rocks in the region (Davies and Jaques, 1984; Robertson et al., 2001). In addition, numerous grains of serpentinite were identified in siltstones and sandstones in the upper part of the succession (see Sharp and Robertson, this volume).

The hemipelagic sediment compositions at Sites 1114 and 1116 on the Moresby Seamount are very similar to those at Site 1108. This supports the suggestion that all three sites formed a laterally continuous depositional basin during Pliocene time, followed in the late PliocenePleistocene time by uplift of the Moresby Seamount related to movement along the Moresby extensional detachment fault (Robertson et al., 2001).

\section{Basinwide Trends}

When all the samples are plotted together on variation diagrams (Fig. F12), it is seen that the majority of samples from all of the sites can be explained by the occurrence of similar mineral phases (Cullers, 1988). The overall diluting effect of $\mathrm{CaO}$ at high values ( $>20 \mathrm{wt} \%$ ) is clear from the $\mathrm{Al}_{2} \mathrm{O}_{3}$ vs. $\mathrm{CaO}$ plot. There are also positive correlations of $\mathrm{Al}_{2} \mathrm{O}_{3}$ with $\mathrm{TiO}_{2}, \mathrm{~K}_{2} \mathrm{O}, \mathrm{Na}_{2} \mathrm{O}$, and $\mathrm{Fe}_{2} \mathrm{O}_{3}$, respectively, although as noted above, there are local exceptions. $\mathrm{MgO}$ varies independently of $\mathrm{Al}_{2} \mathrm{O}_{3}$ where values of the former exceed $4 \mathrm{wt} \%$.
F12. Geochemical variation plots for all sites analyzed, p. 41.

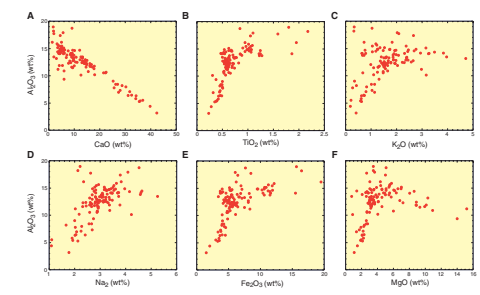


The basin-wide geochemical trends can be explained in the regional geological context, as follows (Fig. F13).

1. The mid-late Miocene turbiditic sediments (Site 1115) in the north were derived from relatively basic calc-alkaline volcanics related to the Trobriand Arc.

2. "Basal" sediments (Sites 1109 and 1115) exhibit input from a local Paleogene ophiolite-related unit presumed to lie to the south.

3. All of the Pliocene successions exhibit similar low-K calc-alkaline sources.

4. The volcanogenic input is strongest and purest at Site 1109, which is located in a sediment feeder channel that probably carried sediment from Trobriand Island and adjacent areas (e.g., Woodlark Island) into the Woodlark rift basin.

5. Continentally derived material is most obvious within the Woodlark rift (Site 1118) and on the Moresby Seamount (Sites 1114 and 1116), where it is mixed with ultramafic detritus probably derived from the Papuan ophiolites, as confirmed by petrographic studies (see Sharp and Robertson, this volume).

6. The late Pleistocene-Holocene was marked by distinctive high-K volcanism, as confirmed by electron microprobe studies of volcanic glass (Lackschewitz et al., 2001).

7. Local iron enrichment above the igneous basement (Sites 1109 and 1115) probably relates to input of oxidized sediment derived from a tropically weathered basement.

\section{Diagenesis}

XRD data combined with pore fluid evidence (Taylor, Huchon, Klaus, et al., 1999; De Carlo et al., this volume) are indicative of diagenetic processes within the Woodlark Basin. The local presence of dolomite (e.g., at Site 1115) may be reflected in a decrease in dissolved $\mathrm{Ca} / \mathrm{Mg}$ ratio in pore water and decreased concentration of dissolved $\mathrm{Mg}^{2+}$ (from 160 to $210 \mathrm{mbsf}$ ). The presence of rare ankerite, determined during shipboard XRD, points to diagenetic reactions involving $\mathrm{Ca}, \mathrm{Mg}$, and Fe. Pyrite is also locally present. Occurrences of chlorite, smectite, and mixed-layer clay (e.g., at Site 1115) can be related to alteration of volcanogenic sediment. Such reactions decrease the soluble $\mathrm{Mg}^{2+}$ in the pore water, as does the presence of authigenic zeolite that was noted at $\sim 600$ mbsf (Taylor, Huchon, Klaus, et al., 1999; see De Carlo et al., this volume). However, the kaolinite and smectite commonly present are assumed to be mainly or entirely detrital, reflecting input from a tropically weathered landmass.

\section{Correlation with Petrographic and Electron Probe Data}

The bulk chemical data can be compared with the major element composition of volcanic glass, as determined by electron microprobe analysis (Lackschewitz et al., 2001). Most of the volcanic glasses analyzed are typical of siliceous calc-alkaline rocks, but some from the Pleistocene document a distinctive high-K calc-alkaline volcanism. Compared to the average composition of the muds analyzed, the typical calc-alkaline glasses exhibit higher values of $\mathrm{SiO}_{2}, \mathrm{Na}_{2} \mathrm{O}$, and $\mathrm{K}_{2} \mathrm{O}$ but lower values of $\mathrm{CaO}, \mathrm{MgO}$, and $\mathrm{FeO} . \mathrm{Al}_{2} \mathrm{O}_{3}$ values are similar or
F13. Inferred palaeocurrent directions, p. 42.

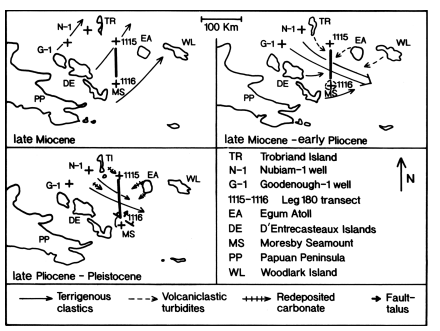


lower, whereas $\mathrm{TiO}_{2}$ is commonly similar or higher, although exceptions exist. Comparisons between glass and mud reveal that only a few are compositionally similar. This is not surprising as ash layers were avoided during shipboard sampling for chemical analysis. Pleistocene sediments (e.g., from Site 1109) are relatively K rich, reflecting input from the distinctive high-K calc-alkaline volcanics mentioned above. The electron probe data, therefore, confirm the widespread presence of magnesium- and iron-rich components of inferred terrigenous origin.

Petrographic studies further indicate that distinctive metamorphic debris marked by schist, gneiss, serpentinite, and rare spinel appears at Sites 1109 and 1115 in sediments of $<3$ Ma. A similar, but less well dated, trend is seen at Site 1108 (see Sharp and Robertson, this volume). Erosion of serpentinite could leave a chemical imprint as high $\mathrm{Cr}$ and Ni. Increased schist and gneiss might be reflected in increased $\mathrm{SiO}_{2}$, $\mathrm{Al}_{2} \mathrm{O}_{3}$, and related terrigenous minor elements (e.g., $\mathrm{Rb}$ ). At Site 1109, no identifiable change in the above terrigenous constituents (e.g., $\mathrm{Al}_{2} \mathrm{O}_{3}, \mathrm{~K}_{2} \mathrm{O}, \mathrm{Na}_{2} \mathrm{O}, \mathrm{Rb}, \mathrm{Zr}, \mathrm{Y}$ ) is observed. However, $\mathrm{MgO}$ levels exceed 5 wt $\%$ in $<3$-Ma sediments (approximately $<150 \mathrm{mbsf}$ ). Also, the highest levels of $\mathrm{Cr}$ and $\mathrm{Ni}$ (but not $\mathrm{Zn}, \mathrm{Cu}$, or $\mathrm{Zr}$ ) occur in younger sediments. For Site 1115, no systematic change is observed in sediments $<3 \mathrm{Ma}$.

An interpretation that rationalizes both the geochemical data on the fine-grained sediments and the petrographic data for the silt- and sandsized sediment is as follows. The area of the Leg 180 drill sites was bordered to the south by the Papua New Guinea landmass during the entire history of Pliocene-Pleistocene basin development. Throughout this time terrigenous sediment from mixed metamorphic, igneous, and ophiolitic source rocks was shed into the basin as it developed. During the Pliocene much of this sediment was derived from the Papua New Guinea highlands well inland (Davies, 1980; Rogerson et al., 1987, 1993). Silt and mud carried by rivers was, however, probably trapped in coastal rift basins. As a result, only fine-grained terrigenous sediment reached the Woodlark Basin during early-mid Pliocene time. This sediment was carried by turbidity currents to all the drill sites. Serpentinized ultramafic rocks were important source lithologies throughout this time. Fine-grained sediment (including detritus from ultramafic rocks) was able to reach the present northern margin of the Woodlark rift as it did not then exist as a deep rift basin (Robertson et al., 2001). Subsequently, during late Pliocene time a discrete pulse of rifting created the present deep Woodlark rift basin. The southern margin of the rift was exhumed (e.g. Moresby Seamount) and in places exposed subaerially (e.g. D'Entrecasteaux Islands and onshore Cape Vogel Basin) (Davies, 1980; Hill et al., 1992). Consequently, a more proximal source of terrigenous sediment was created (after $3 \mathrm{Ma}$ ) including metamorphic, igneous and ophiolitic rocks, as reflected in the appearance of siltand sand-sized schist, gneiss, muscovite, biotite, serpentinite, and spinel grains (see Sharp and Robertson, this volume). In addition, microprobe studies have confirmed the presence of high-K calc-alkaline volcanism after 2.5 Ma (Lackschewitz et al., 2001). By this stage, the northern rift flanks (Sites 1109 and 1115) were largely isolated from terrigenous sediment input resulting in a change in chemical composition. 


\section{Regional Comparisons}

Insights into the interpretation of the Woodlark geochemical data sediments come from comparisons with a number of marine and land settings. Bulk chemical composition is well known to relate to provenance and tectonic setting (Bhatia, 1983; Bhatia and Crook, 1986; Floyd and Leveridge, 1987; Roser and Korsch, 1986). For example, geochemical data may allow the recognition of specific source terrains (e.g., craton vs. volcanic arc), changes in source through time (e.g., collision of an arc with a continental margin), or different sediment pathways from contrasting source areas within a single basin system. Three settings for which comparable data are available from deep-sea drilling include (1) southwest Pacific arc-marginal basin-type settings (e.g., Lau and Mariana backarc basins); (2) active continental margin (e.g., Nankai Trough and Shikoku Basin); and (3) Passive continental margins (e.g., Blake-Bahama Basin and northeast Atlantic Madeira Abyssal Plain).

\section{SW Pacific Marginal Basins}

Exemplifying the intraoceanic marginal basin settings with no continental margin input is the Lau backarc basin (Bloomer et al., 1995). Bednarz and Schmicke (1991) reported bulk-chemical analyses of the main sediment types within the Lau Basin. Most of these sediments are relatively coarse grained sands and silts, compared to the hemipelagic sediments analyzed from the Woodlark Basin. Taken as a whole, the Woodlark Basin sediments exhibit lower $\mathrm{SiO}_{2}$, similar $\mathrm{MgO}$, similar or higher $\mathrm{K}_{2} \mathrm{O}$, higher $\mathrm{Al}_{2} \mathrm{O}_{3}$, much higher $\mathrm{Cr}$ and $\mathrm{Ni}$, and also higher $\mathrm{Rb}$ and $\mathrm{Ba}$. Petrographic data and electron microprobe studies indicate that much of the volcaniclastic sediment was derived from low-K calcalkaline basaltic andesites to rhyolites. Specifically, volcaniclastic turbidites from Site 834 and 835 composed of basaltic turbidities (3.3 Ma) were derived from calc-alkaline volcanics within the backarc Lau Ridge. These sediments are compositionally similar to many of the volcaniclastic turbidites of the Pliocene Woodlark Basin successions. In addition, in the Lau Basin, locally high $\mathrm{K}_{2} \mathrm{O}$, high $\mathrm{Al}_{2} \mathrm{O}_{3}$, low $\mathrm{TiO}_{2}$, low $\mathrm{FeO}$, and low $\mathrm{MgO}$ relate to the presence of high-K calc-alkaline tephra. This is similar in composition to the high-K calc-alkaline tephra from the late Pleistocene-Holocene interval in the Woodlark Basin.

The most striking chemical difference between the Woodlark and the Lau Basin sediments is the very high values of $\mathrm{Cr}$ and $\mathrm{Ni}$ (also locally of $\mathrm{Cu}$ and $\mathrm{Zn}$ ) in the many of the Woodlark Basin hemipelagic sediments. Values far exceed levels compatible with normal calc-alkaline volcanic rocks (basaltic andesite-rhyolites). The high values correspond to intervals in which abundant turbiditic volcaniclastic siltstone/sandstone are present, as indicated by XRD and petrographic studies (see Sharp and Robertson, this volume), and an ultramafic source from the Paleogene Papuan ophiolites is inferred.

\section{Active Continental Margins}

Exemplifying the varied sources possible in active margin settings is Site 808 is the Shikoku Basin, which received fine-grained muds from $\sim 14 \mathrm{Ma}$ to recent time from the Izu collision zone, mainland Japan, and the Honshu arc. A large data set of major, trace, and REEs was published for bulk samples of muds and mudstones (Pickering et al., 1993). The sediment composition remains remarkably constant upsection, in 
marked contrast with the Woodlark and Lau backarc settings discussed above. The Woodlark Basin sediments exhibit relatively low $\mathrm{SiO}_{2}, \mathrm{TiO}_{2}$, and $\mathrm{Al}_{2} \mathrm{O}_{3}$ but high $\mathrm{Mg}$ and $\mathrm{CaO}$. The Woodlark sediments also contain more $\mathrm{Cu}, \mathrm{Ni}, \mathrm{Zr}$, and $\mathrm{Sr}$ and less $\mathrm{Rb}$. These differences can mainly be explained by a greater volcanogenic than terrigenous input in the Woodlark Basin.

\section{Passive Continental Margins}

Exemplifying a passive margin setting is the east Atlantic Iberia Abyssal Plain. Studies of this area allow chemical discrimination of differing sediment transport pathways from the Canary Islands and from the African continental margin (De Lange et al., 1987; Pearce and Jarvis, 1995). In general, fine-grained sediments with high $\mathrm{Ti}, \mathrm{Fe}, \mathrm{Mg}$, Zr, and $\mathrm{V}$ and many other trace elements occur together with lithic grains of basalt, pumice, trachyte, volcanic glass, and heavy minerals (amphibole, pyroxene, rutile, sphene, and zircon) that together characterize Canary Island sources. By contrast, sediments (often organic rich) with relatively high $\mathrm{Si}, \mathrm{Al}, \mathrm{K}, \mathrm{Li}$, and $\mathrm{Sm}$, coupled with high quartz, feldspar, and clays (e.g., illite, smectite, and kaolinite) characterize North African continental margin sources. Compared to the above sediments, the Woodlark Basin volcanogenic sediments exhibit lower $\mathrm{TiO}_{2}$, reflecting a source related to calc-alkaline rather than within-plate (hotspot) basic extrusive rocks. A number of the Woodlark Basin samples (e.g., from Site 1118) are relatively enriched in $\mathrm{Al}_{2} \mathrm{O}_{3}, \mathrm{~K}_{2} \mathrm{O}$, and $\mathrm{Zr}$, suggesting a continental influence, although igneous-derived material is also abundant.

\section{Ophiolitic Source Terrains}

No chemical data for the composition of modern sediments draining the Papuan ophiolite and related units are known to be published. However, useful comparisons can be made with other areas where such data do exist. One such is the Tethyan orogen in southern Turkey. In this area, a low-grade metamorphic succession and overlying carbonate platform were overthrust by a regionally extensive ophiolite in latest Cretaceous time. During the mid-Tertiary this area was exhumed related to extensional faulting, giving rise to nonmarine ophiolite derivedsediments (Jaffey and Robertson, 2001). Early sediments are very rich in ophiolitic detritus, which waned later as the ophiolite was eroded, leaving only localized remnants today. Whole-rock chemical analysis of associated mud rocks (Jaffey, 2001) shows that these sediments are very calcareous, reflecting erosion of a carbonate platform. Other constituents are correspondingly diluted. However, $\mathrm{Ni}$ and $\mathrm{Cr}$ exhibit similar or higher values than some of the Woodlark Basin muds, reflecting the known erosion of ultramafic ophiolitic rocks. Conversely, the relative abundance of $\mathrm{Na}_{2} \mathrm{O}$ and $\mathrm{K}_{2} \mathrm{O}$ in the Woodlark Basin sediments partly reflects the major volcanogenic input, as confirmed by electron microprobe analysis of glass (Lackschewitz et al., 2001), in contrast to the situation in southern Turkey.

The above comparisons, therefore, support the interpretation of the Woodlark Basin sediments as mainly derived from calc-alkaline volcanogenic sources but with a significant terrigenous input from Papua New Guinea, the D'Entrecasteaux Islands, or now-submerged adjacent areas, especially from ultramafic ophiolitic and metamorphic rocks (Fig. F13). 


\section{CONCLUSIONS}

1. Fine-grained sediments (clays, claystones/muds, and mudstones) of latest Miocene-Holocene age, which volumetrically dominate the Woodlark Basin, are partly of volcanogenic origin, derived mainly from a calc-alkaline volcanic centers. In addition, terrigenous sediment was derived from the Papua New Guinea landmass, the D'Entrecasteaux Islands, the onshore Cape Vogel Basin, and adjacent now-submerged areas.

2. The most northerly sites on the northern rift flank (Site 1115) penetrated a mid-late Miocene forearc succession, including relatively $\mathrm{Mg}$ and $\mathrm{K}$ rich volcanogenic fine-grained sedimentary rocks interpreted as derived from relatively mafic calc-alkaline volcanic centers. This volcanism was related to southward subduction of oceanic crust beneath the Miocene Trobriand arc.

3. K-poor, relatively Ti-rich fine-grained sedimentary rocks associated with conglomerates that unconformably overly massive dolerite are inferred to have been derived from mafic igneous rocks, probably related to the Paleogene Papuan ophiolite.

4. Fe-rich fine-grained sedimentary rocks above basalt/diabase conglomerates at both Sites 1109 and 1118 reflect deposition of strongly weathered material from a tropically weathered landmass.

5. Common occurrence of smectite and kaolinite at all sites reflects tropical weathering of land source areas.

6. Very high absolute abundances of the trace metals $\mathrm{Cr}$ and $\mathrm{Ni}$ (also $\mathrm{Cu}$ and $\mathrm{Zn}$, locally) occur sporadically throughout the Pliocene successions at all sites and are attributed to input from ultramafic rocks of the Paleogene Papuan ophiolites or their alternation products (e.g., crysotile, talc, and chlorite). The probable source was the internal highlands. Exclusively fine-grained terrigenous sediment reached all parts of the present western Woodlark Basin during early-middle Pliocene time, prior to development of the present deep rift basin. Coarse sediment was probably trapped in peripheral basins at this stage.

7. Fine-grained terrigenous-derived sediment occurs at all sites in the Woodlark Basin, as recorded by relatively high $\mathrm{Al}, \mathrm{K}, \mathrm{Na}$, and minor elements, including $\mathrm{Rb}, \mathrm{Zr}$, and $\mathrm{Y}$. Terrigenous input is, however, most marked at Site 1118 in the Woodlark rift.

8. The presence of mixed terrigenous and ultramafic in addition to volcanogenic constituents is interpreted to indicate that all of the sites formed part of a single turbiditic basin (or several subbasins) during Pliocene time, until uplift of the southern rift flank to form the Moresby Seamount in late Pliocene-Pleistocene time. Low-density turbidity currents were presumably able to reach all parts of the Woodlark Basin until late Pliocene time when terrigenous input to the northern rift margin was cut off, probably as a result of deepening of the Woodlark rift to the south.

9. Complementary petrographic studies (see Sharp and Robertson, this volume) reveal input of silt-sand-sized terrigenous schist, gneiss, and serpentinite within sediments of $<3 \mathrm{Ma}$ at several sites in the Woodlark Basin (1109 and 1108). However, no corresponding increase in lithogenous chemical constituents is seen at this time in the composition of the fine-grained sedi- 


\section{A.H.F. ROBERTSON AND T.R. SHARP}

ments. This is probably because fine-grained terrigenous sediment was derived from adjacent land areas and accumulated within the Woodlark Basin throughout its late Miocene-Holocene history. By contrast, coarser gained sediment only reached the basin after $3 \mathrm{Ma}$, following a pulse of rifting and exhumation of the southern rift margins (e.g., in the D'Entrecasteaux Islands and Cape Vogel Basin).

10. The uppermost volcanogenic muds rich in volcanic ash (Sites 1109 and 1115) were derived from a distinctive high-K calcalkaline volcanic source, probably derived from distinctive highK calc-alkaline volcanoes in the Dawson Straits, Moresby Strait, or Dobu Island (Lackschewitz et al., 2001).

\section{ACKNOWLEDGMENTS}

The first author thanks Doodie James for help with analysis and Geoff Angel with XRD analysis. We also thank Klas Lackschewitz for making available electron microprobe data for comparisons. Prof. Keith Crook is thanked for his careful review of the paper. This research used samples and/or data provided by the Ocean Drilling Program (ODP). ODP is sponsored by the U.S. National Science Foundation (NSF) and participating countries under management of Joint Oceanographic Institutions (JOI), Inc. Funding for this research was provided by Rapid Response Grant from the U.K. Natural Environmental Research Council to the first author. The second author thanks the Australian ODP Secretariat for a small postcruise grant. 


\section{REFERENCES}

Ashley, P.M., and Flood, R.H., 1981. Low-K tholeiites and high-K igneous rocks from Woodlark Island, Papua New Guinea. J. Geol. Soc. Aust., 28:227-240.

Bhatia, M.R., 1983. Plate tectonics and geochemical composition of sandstones. $J$. Geol., 91:611-627.

Bhatia, M.R., and Crook, K.A.W., 1986. Trace element characteristics of graywackes and tectonic setting discrimination of sedimentary basins. Contrib. Mineral. Petrol., 92:181-193.

Bednarz, U., and Schmincke, H.-U., 1994. Composition and origin of volcaniclastic sediments in the Lau Basin (southwest Pacific), Leg 135 (Sites 834-839). In Hawkins, J., Parson, L., Allan, J., et al., Proc. ODP, Sci. Results, 135: College Station, TX (Ocean Drilling Program), 51-74.

Benes, V., Scott, S.D., and Binns, R.A., 1994. Tectonics of rift propagation into a continental margin: western Woodlark Basin, Papua New Guinea. J. Geophys. Res., 99:4439-4455.

Bloomer, S.H., Taylor, B., MacLeod, C.J., Stern, R.J., Fryer, P., Hawkins, J.W., and Johnson, L., 1995. Early arc volcanism and the ophiolite problem: a perspective from drilling in the western Pacific. In Taylor, B., and Natland, J. (Eds.), Active Margins and Marginal Basins of the Western Pacific. Geophys. Monogr., Am. Geophys. Union, 88:1-30.

Cullers, R.L., 1988. Mineralogical and chemical changes of soil and stream sediment formed by intense weathering of the Danburg Granite, Georgia USA. Lithos, 21:301-314.

Davies, H.L., 1980. Folded thrust fault and associated metamorphics in the SucklingDayman Massif, Papua New Guinea. Am. J. Sci., 280-A:171-191.

Davies, H.L., Honza, E., Tiffin, D.L., Lock, J., Okuda, Y., Keene, J.B., Murakami, F., and Kisimoto, K., 1987. Regional setting and structure of the western Solomon Sea. Geo-Mar. Lett., 7:153-160.

Davies, H.L., and Jaques., A.L. 1984. Emplacement of ophiolite in Papua New Guinea. In Gass, I.G., Lippar, S.J., and Shelton, A.W. (Eds.), Ophiolites and Oceanic Lithosphere. Spec. Publ.-Geol. Soc., London, 13:341-350.

Deer, W.A., Howie, R.A., and Zussman, J., 1975. An Introduction to the Rock-Forming Minerals: New York (Longman).

De Lange, G.J., Jarvis, I., and Kuijpers, A., 1987. Geochemical characteristics and provenance of late Quaternary sediments from the Madeira Abyssal Plain, North Atlantic. In Weaver, P.P.E., and Thomson, J. (Eds.), Geology and Geochemistry of Abyssal Plains. Spec. Publ.-Geol. Soc. London, 31:147-165.

Fitton, J.G., Saunders, A.D., Larsen, L.M., Hardarson, B.S., and Norry, M.J., 1998. Volcanic rocks from the southeast Greenland Margin at $63^{\circ} \mathrm{N}$ : composition, petrogenesis, and mantle sources. In Saunders, A.D., Larsen, H.C., and Wise, S.W., Jr. (Eds.), Proc. ODP, Sci. Results, 152: College Station, TX (Ocean Drilling Program), 331-350.

Floyd, P.A., and Leveridge, B.E., 1987. Tectonic environment of the Devonian Gramscatho Basin, south Cornwall: framework mode and geochemical evidence from turbiditic sandstones. J. Geol. Soc. London, 144:531-542.

Gromet, L.P., Dymek, R.F., Haskin, L.A., and Korotev, R.L., 1984. The "North American Shale Composite": its compilation, major and trace element characteristics. Geochim. Cosmochim. Acta, 48:2469-2482.

Harris, C.S., Varol, O., and Mortimer, C.P., 1985. Biostratigraphy of the Goodenough-1 and Nubiam-1 Wells from the Cape Vogel Basin and the L'etoile-1 Well from the Bougainville Basin. Robertson Res. Rpt., 1486.

Hill, E.J., Baldwin, S.L., and Lister, G.S., 1992. Unroofing of active metamorphic core complexes in the D'Entrecasteaux Islands, Papua New Guinea. Geology, 20:907910. 
Honza, E., Davies, H.L., Keene, J.B., and Tiffin, D.L., 1987. Plate boundaries and evolution of the Solomon Sea region. Geo-Mar. Lett., 7:161-168.

Jaffey, N. 2001. Tectonic-sedimentary history of the Tertiary Ecemis strike-slip fault zone, Southern Turkey [Ph.D. thesis]. University of Edinburgh.

Jaffey, N., and Robertson, A.H.F., 2001. New sedimentological and structural data from the Ecemis fault zone, southern Turkey; implications for its timing and offset and the Cenozoic tectonic escape of Anatolia. J. Geol. Soc. London, 158: 367-378.

Lackschewitz, K., Bogaard, P.V.D., and Mertz, D.F., 2001. ${ }^{40} \mathrm{Ar} /{ }^{39} \mathrm{Ar}$ ages of fallout tephra layers and volcaniclastic deposits in the sedimentary succession of the western Woodlark Basin, Papua New Guinea: The marine record of Miocene-Pleistocene volcanism. In Wilson, R.C.L., Whitmarsh, R.B., Taylor, B, and Froitzheim, N (Eds.), Non-volcanic Rifting of Continental Margins: A Comparison of Evidence from Land and Sea. Spec. Publ.-Geol. Soc. London, 187:373-388.

Lock, J., Davies, H.L., Tiffin, D.L., Murakami, F., and Kisomoto, K., 1987. The Trobriand subduction system in the western Solomon Sea. Geo-Mar. Lett., 7:129-134.

Pearce, T.J., and Jarvis, I., 1995. High-resolution chemostratigraphy of Quaternary distal turbidites: a case study of new methods for the analysis and correlation of barren sequences. In Dunay, R.E., and Hailwood, E.A. (Eds.), Non-biostratigraphical Methods of Dating and Correlation. Spec. Publ.—Geol. Soc. London, 89:107-143.

Pickering, K.T., Marsh, N.G., and Dickie, B., 1993. Data report: Inorganic major, trace, and rare earth element analyses of the muds and mudstones from Site 808. In Hill, I.A., Taira, A., Firth, J.V., et al., Proc. ODP, Sci. Results, 131: College Station, TX (Ocean Drilling Program), 427-450.

Robertson, A.H.F., Awadallah, S.A.M., Gerbaudo, S., Lackschewitz, K.S., Monteleone, B.D., Sharp, T.R., and the ODP Leg 180 Shipboard Scientific Party, 2001. Evolution of the Miocene-Recent Woodlark Rift Basin, SW Pacific, inferred from sediments drilled during Ocean Drilling Program Leg 180. In Wilson, R.C.L., Whitmarsh, R.B., Taylor, B, and Froitzheim, N (Eds.), Non-volcanic Rifting of Continental Margins: A Comparison of Evidence from Land and Sea. Spec. Publ.-Geol. Soc. London, 187:335372.

Rogerson, R., Hilyard, D., Francis, G., and Finlayson, E.J., 1987. The foreland thrust belt of Papua New Guinea. Proc. Pac. Rim Congr., 87:579-583.

Rogerson, R., Queen, L., and Francis, G., 1993. The Papuan ultramafic belt arc complex. In Wheller, G.E. (Ed.), Islands and Basins: Correlation and Comparison of Onshore and Offshore Geology. CCOP/SOPAC Misc. Rept., 159:28-29.

Roser, B.P., and Korsch, R.J., 1986. Determination of tectonic setting of sandstonemudstone suites using $\mathrm{SiO}_{2}$ content and $\mathrm{K}_{2} \mathrm{O} / \mathrm{Na}_{2} \mathrm{O}$ ratio. J. Geol., 4:635-650.

Smith, I.E.M., 1982. Volcanic evolution in eastern Papua. Tectonophysics, 87:315-333.

Smith, I.E.M., Chappell, B.W., Ward, G.K., and Freeman, R.S., 1977. Peralkaline rhyolites associated with andesitic arcs of the southwest Pacific. Earth Planet. Sci. Lett., 37:230-236.

Smith, I.E.M., and Johnson, R.W., 1981. Contrasting rhyolite suites in the late Cenozoic of Papua New Guinea. J. Geophys. Res., 86:10257-10272.

Smith, I.E.M., and Milsom, J.S., 1984. Late Cenozoic volcanism and extension in eastern Papua. In Kokelaar, B.P., and Howells, M.F. (Eds.), Marginal Basin Geology. Spec. Publ.-Geol. Soc. London, 16:163-171.

Stolz, A.J., Davies, G.R., Crawford, A.J., and Smith, I.E.M., 1993. Sr, Nd and Pb isotopic compositions of calc-alkaline and peralkaline silicic volcanics from the D'Entrecasteaux Islands, Papua New Guinea, and their tectonic significance. Mineral. Petrol., 47:103-126.

Taylor, B., Goodliffe, A., Martinez, F., and Hey, R., 1995. Continental rifting and initial sea-floor spreading in the Woodlark Basin. Nature, 374:534-537.

Taylor, B., Goodliffe, A.M., and Martinez, F., 1999. How continents break up: insights from Papua New Guinea. J. Geophys. Res., 104:7497-7512. 


\section{A.H.F. RobertSON AND T.R. SHARP}

Taylor, B., Huchon, P., Klaus, A., et al., 1999. Proc. ODP, Init. Repts., 180 [CD-ROM]. Available from: Ocean Drilling Program, Texas A\&M University, College Station, TX 77845-9547, U.S.A.

Turekian, K.K., and Wedepohl, K.H., 1961. Distribution of the elements in some major units of the earth's crust. Geol. Soc. Am. Bull., 72:175-192.

Weissel, J.K., Taylor, B., and Karner, G.D., 1982. The opening of the Woodlark basin, subduction of the Woodlark spreading system, and the evolution of northern Melanesia since mid-Pliocene time. Tectonophysics, 87:253-277. 


\section{A.H.F. ROBERTSON AND T.R. SHARP}

Figure F1. Regional tectonic setting of the Woodlark rift adjacent to the Papuan Peninsula; inset: wider regional setting. G-1 = Goodenough-1 well, N-1 = Nubiam-1 well, CV = Cape Vogel Basin (onshore), E = Egum Island, $\mathrm{F}=$ Fergusson Island, $\mathrm{G}=$ Goodenough Island, $\mathrm{MB}=$ Milne Bay, $\mathrm{MS}=$ Moresby Seamount, $\mathrm{N}=$ Normanby Island, $\mathrm{Tr}=$ Trobriand Island, $\mathrm{W}=$ Woodlark Island (modified from the Leg 180 Initial Reports volume [Taylor, Huchon, Klaus et al., 1999]).

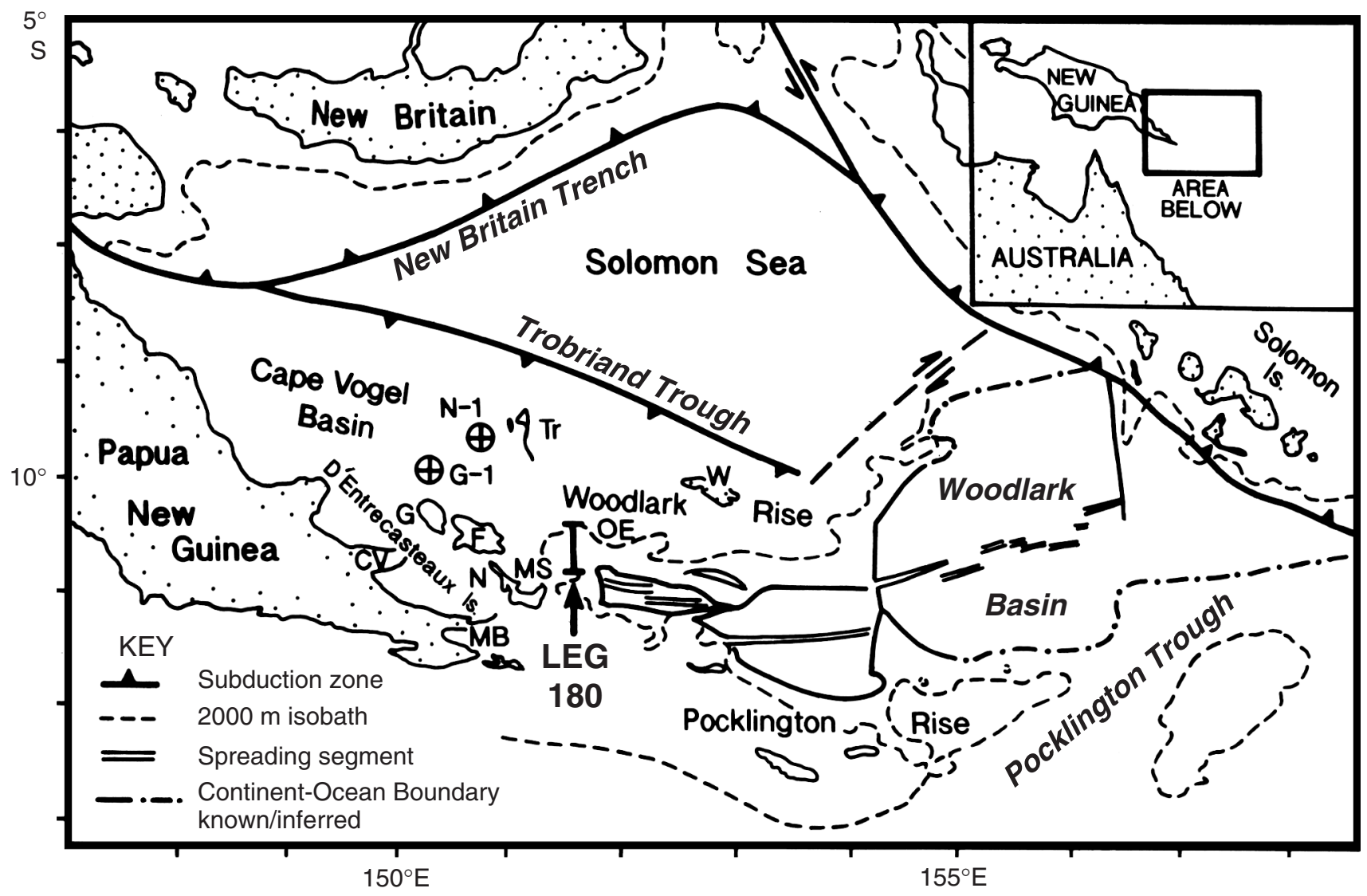


A.H.F. ROBERTSON AND T.R. SHARP

Mixed Volcanogenic/TerRigenous Hemipelagic Sediments

Figure F2. Locations of sites drilled during Leg 180 (modified from the Leg 180 Initial Reports volume [Taylor, Huchon, Klaus et al., 1999]).

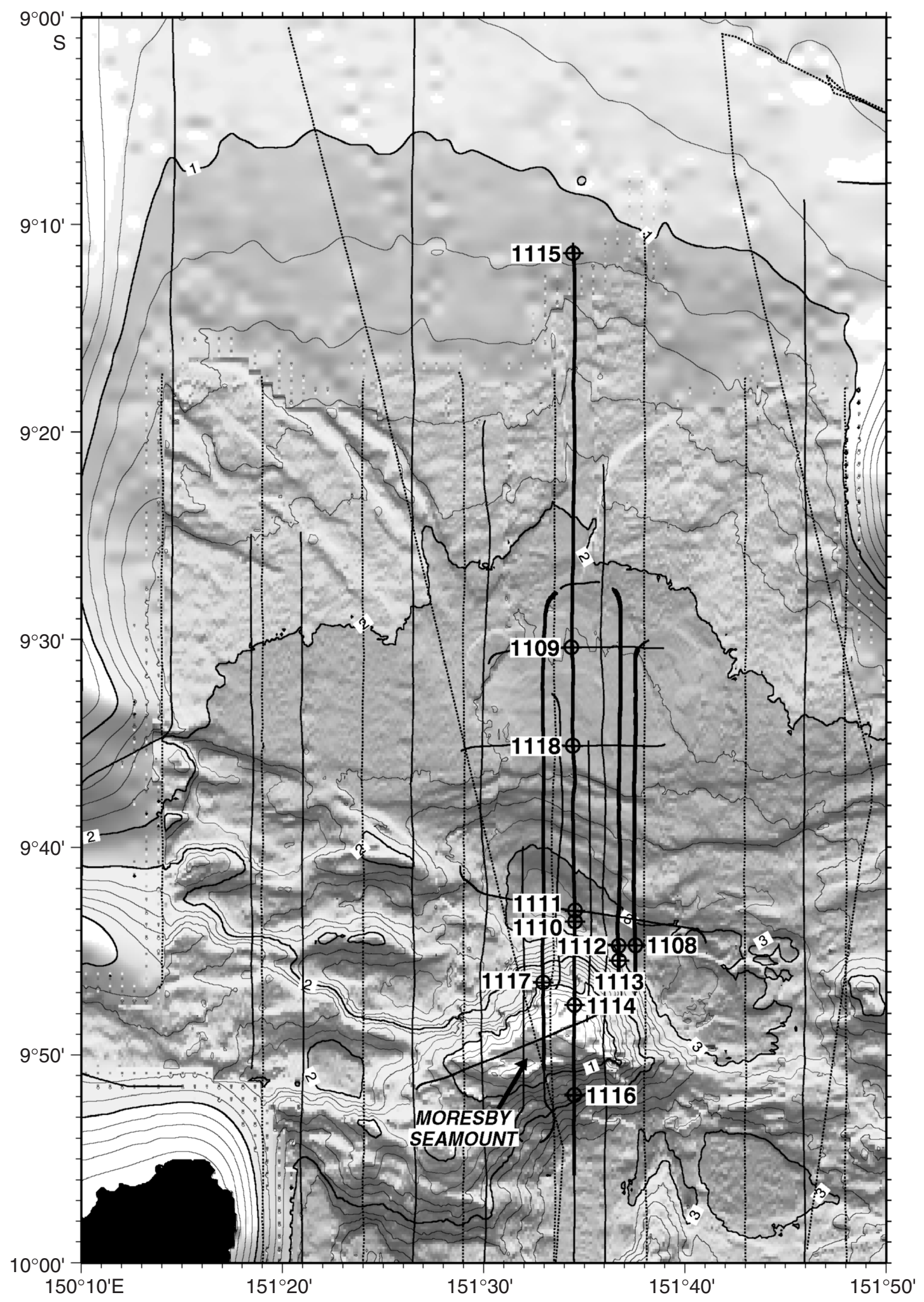




\section{A.H.F. RobertSON AND T.R. SHARP}

Figure F3. Line diagrams showing interpretations of north-south seismic profiles along which the Leg 180 sites were drilled. The original seismic data are in Taylor et al. (1995). A. Westerly profile. B. Easterly profile. See Figure F2, p. 29 for locations.

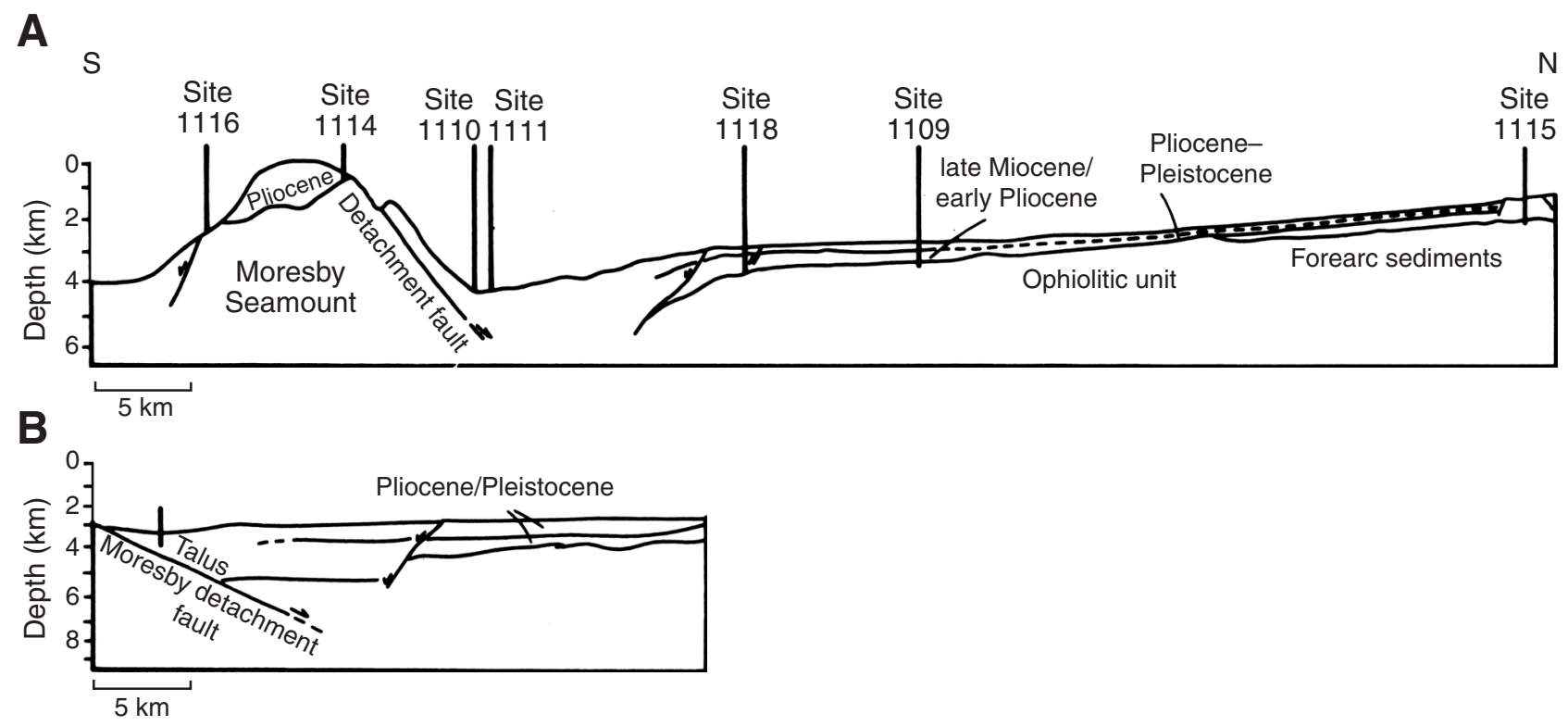




\section{A.H.F. RobertSON AND T.R. SHARP Mixed Volcanogenic/Terrigenous Hemipelagic Sediments}

Figure F4. Age-depth chart for the Leg 180 sites, including a summary of inferred sedimentation rates and depths (below) complied by the Leg 180 shipboard biostratigraphers and magnetostratigraphers, after Takahashi et al., this volume. Solid line $=$ sedimentation curve at Site 1115 , dashed line = sedimentation curve at Site 1109, dotted line = sedimentation curve at Site 1118, solid line (upper right) = sedimentation curve at Site 1108, dashed line (upper right) = sedimentation curve at Site 1114, dotted line (upper right) = sedimentation curve at Site 1116. Square $=$ based on nannofossil datum events, circle $=$ planktonic foraminifer datum events, triangle = magnetic chron and subchron boundaries, star $=$ lithostratigraphic correlation shaded to differentiate sites. Symbols with arrows = actual datum point can be above or below and older or younger than indicated by the symbols. Wavy lines = unconformities. Shown below are average sedimentation rates in $\mathrm{m} / \mathrm{m}$.y. (calculated for intervals separated by vertical lines and palaeobathymetry) based on benthic foraminifers at Sites 1115, 1109, and 1118. Broken lines = uncertainty in the placement of palaeodepth boundaries.

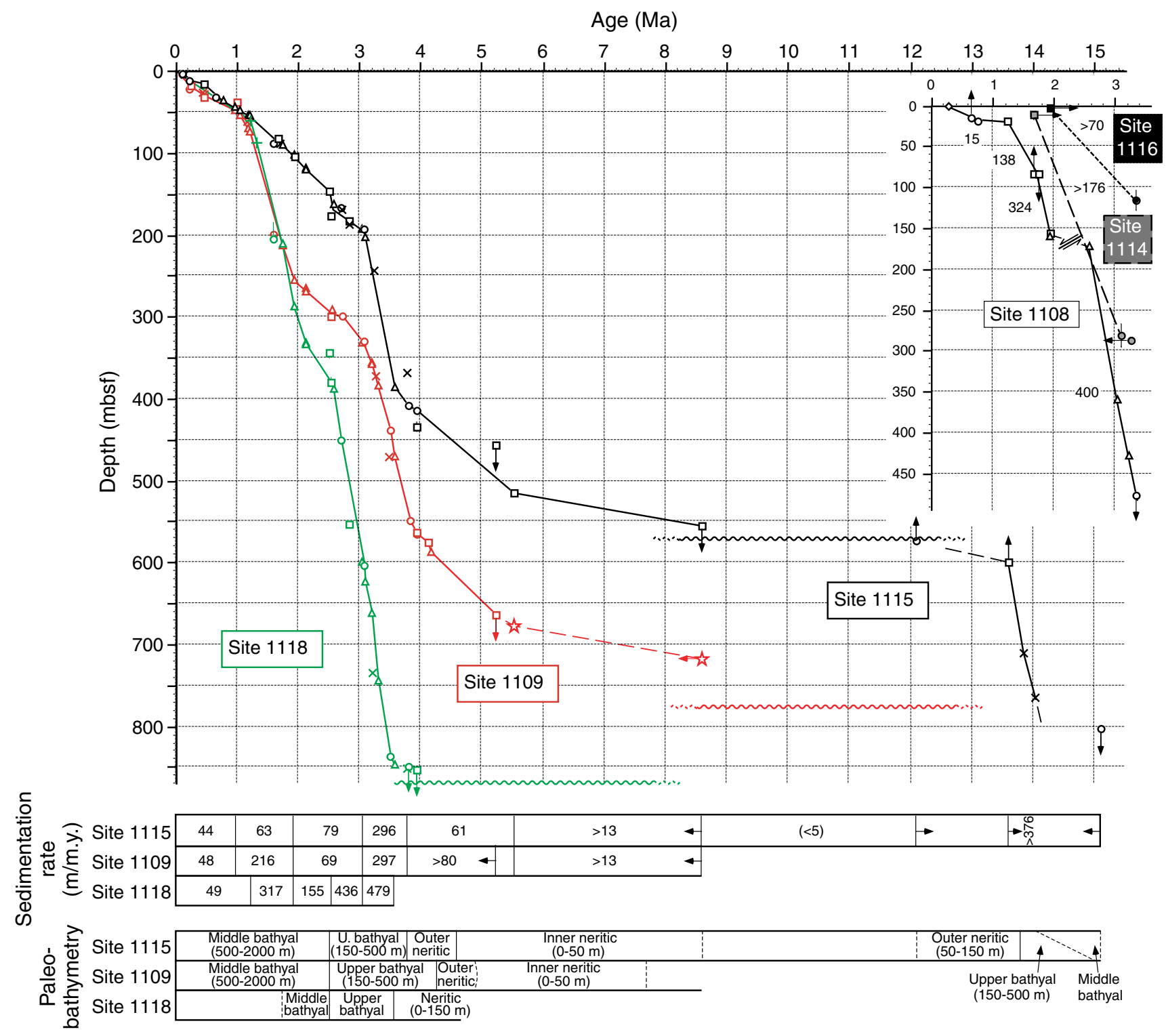




\section{A.H.F. ROBERTSON AND T.R. SHARP}

Figure F5. Summary of the sedimentary successions drilled on northern margin sites of the Woodlark rift (modified after Taylor, Huchon, Klaus et al., 1999).

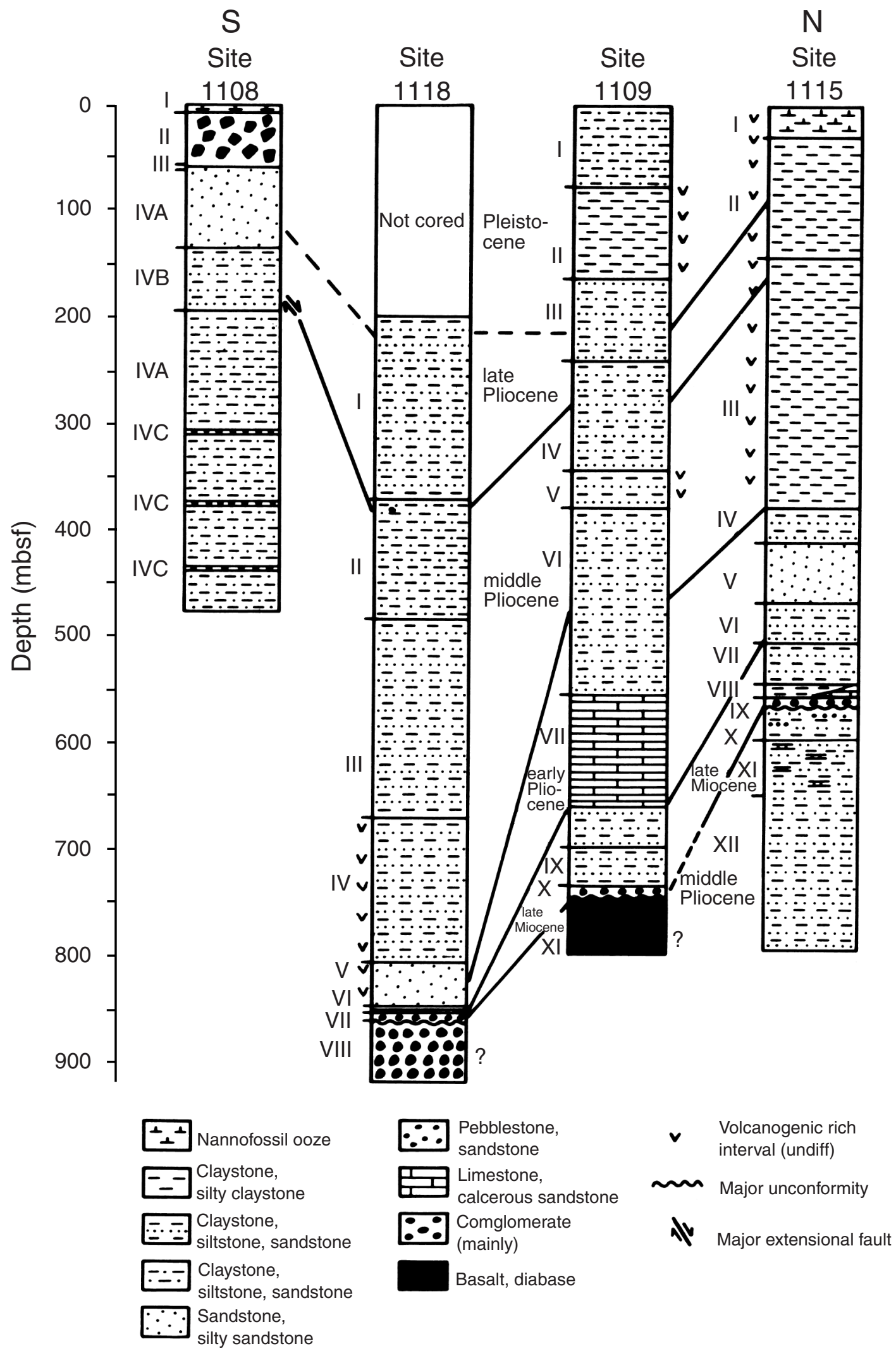


Figure F6. Geochemical variation plots for Site 1115. A. CaO vs. $\mathrm{Al}_{2} \mathrm{O}_{3}$. B. $\mathrm{Al}_{2} \mathrm{O}_{3}$ vs. $\mathrm{TiO}_{2}$. C. $\mathrm{Al}_{2} \mathrm{O}_{3}$ vs. $\mathrm{Fe}_{2} \mathrm{O}_{3}$. D. CaO vs. $\mathrm{MgO}$. E. CaO vs. Cr. F. $\mathrm{Al}_{2} \mathrm{O}_{3}$ vs. $\mathrm{K}_{2} \mathrm{O}$. See Table $\mathrm{T} 2$ for XRF data.
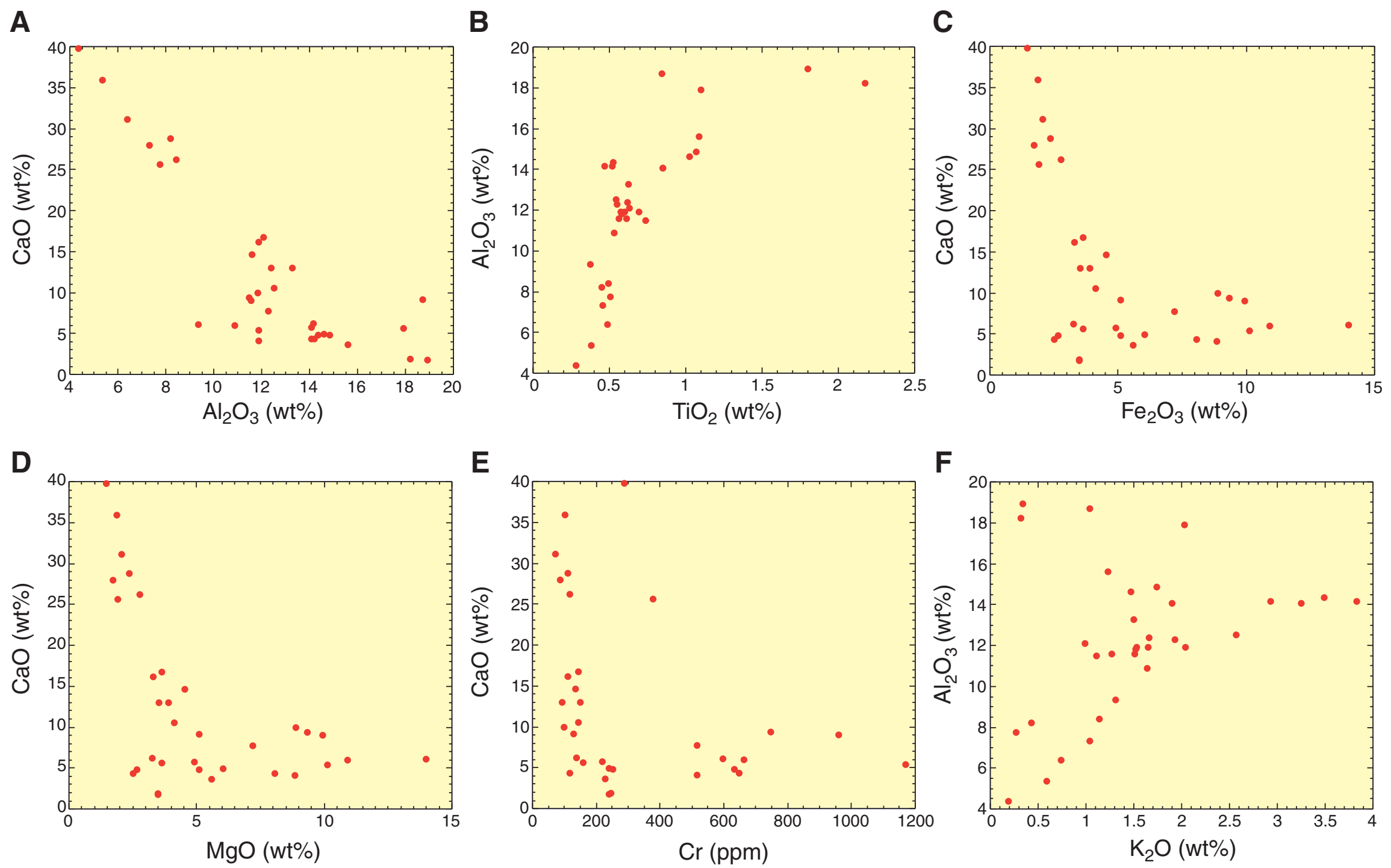
Figure F7. Variation in chemical composition vs. depth for Site 1115. A. CaO. B. $\mathrm{Al}_{2} \mathrm{O}_{3}$. C. $\mathrm{SiO}_{2}$. D. $\mathrm{Na}_{2} \mathrm{O}$. E. Cr.

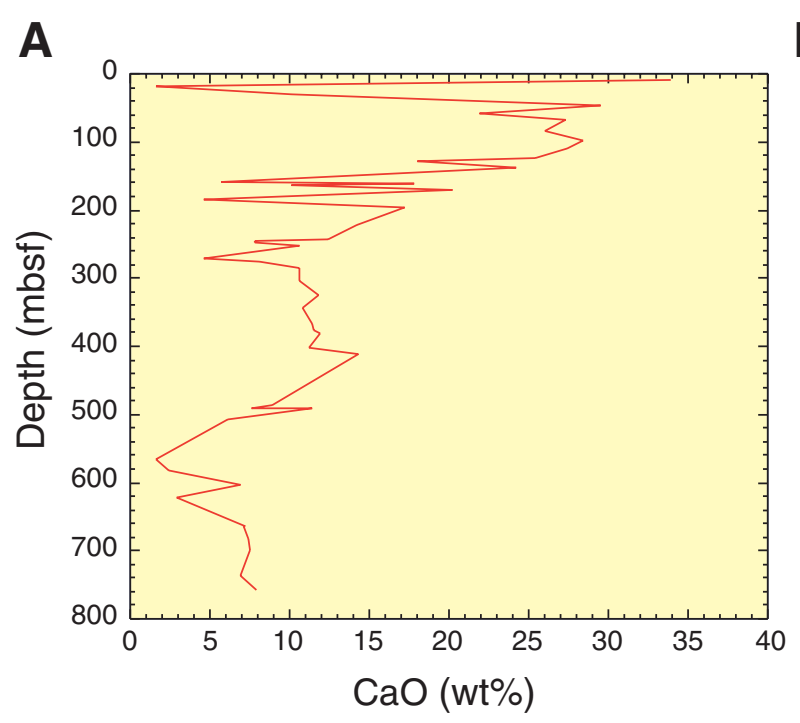

B

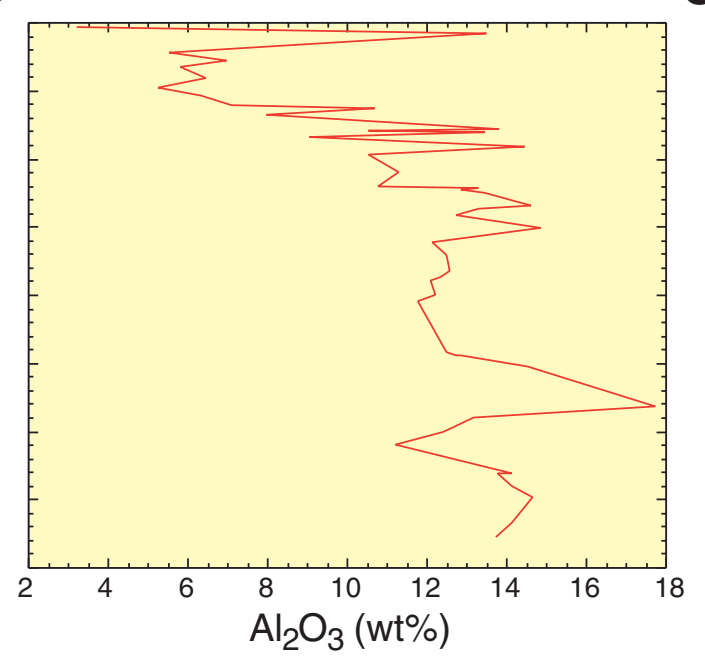

C

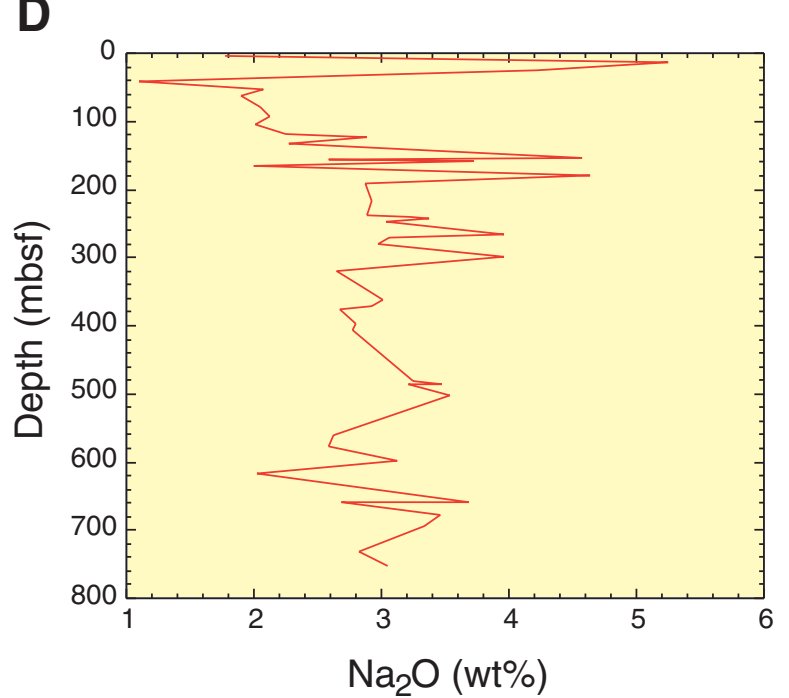

E
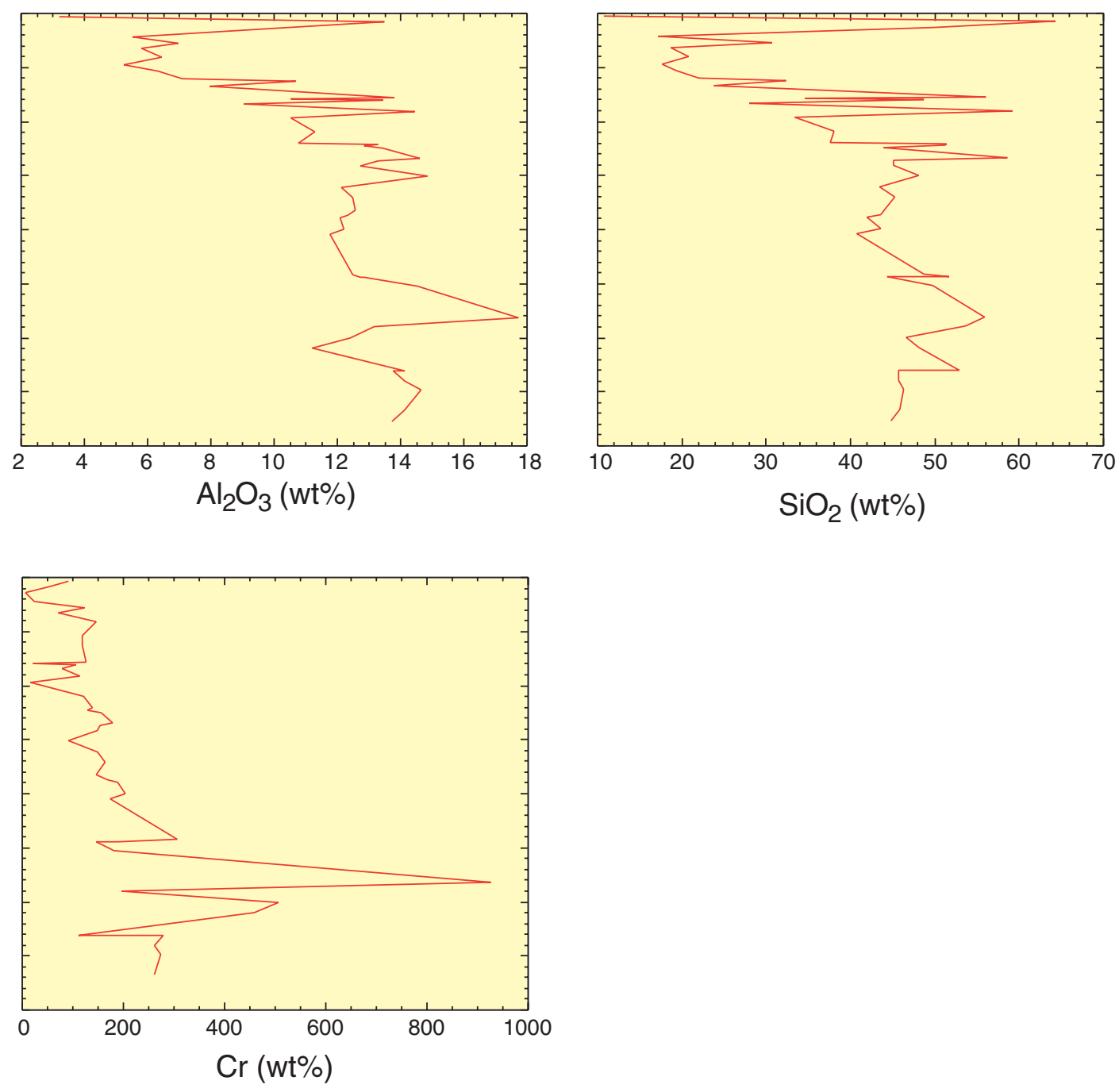
Figure F8. Geochemical variation plots for Site 1109. A. $\mathrm{Al}_{2} \mathrm{O}_{3}$ vs. $\mathrm{CaO}$. B. $\mathrm{Al}_{2} \mathrm{O}_{3}$ vs. $\mathrm{K}_{2} \mathrm{O}$. C. Cr vs. Ni.
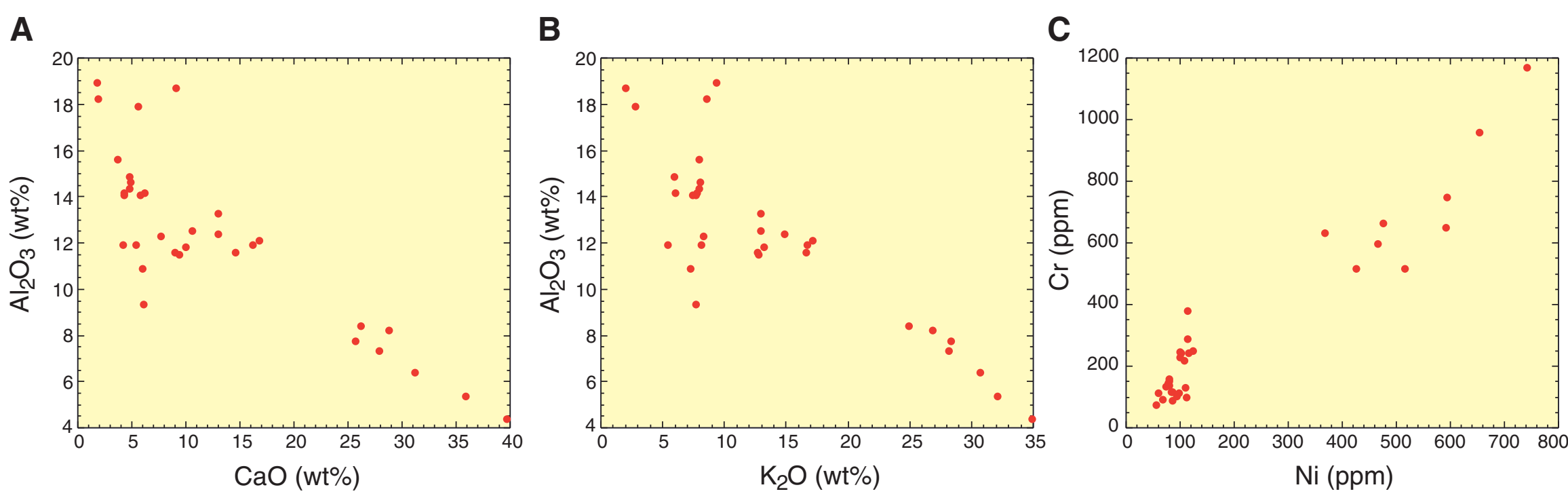
Figure F9. Geochemical variation plots for Site 1118. A. $\mathrm{Al}_{2} \mathrm{O}_{3}$ vs. $\mathrm{Na}_{2} \mathrm{O}$. B. $\mathrm{Al}_{2} \mathrm{O}_{3}$ vs. $\mathrm{SiO}_{2} \cdot$ C. $\mathrm{Al}_{2} \mathrm{O}_{3}$ vs. $\mathrm{K}_{2} \mathrm{O} . \mathrm{D} \cdot \mathrm{Al}_{2} \mathrm{O}_{3}$ vs. TiO . E. $\mathrm{Al}_{2} \mathrm{O}_{3}$ vs. $\mathrm{Zr}$. F. $\mathrm{Al}_{2} \mathrm{O}_{3}$ vs. Y. (Continued on the next two pages.)
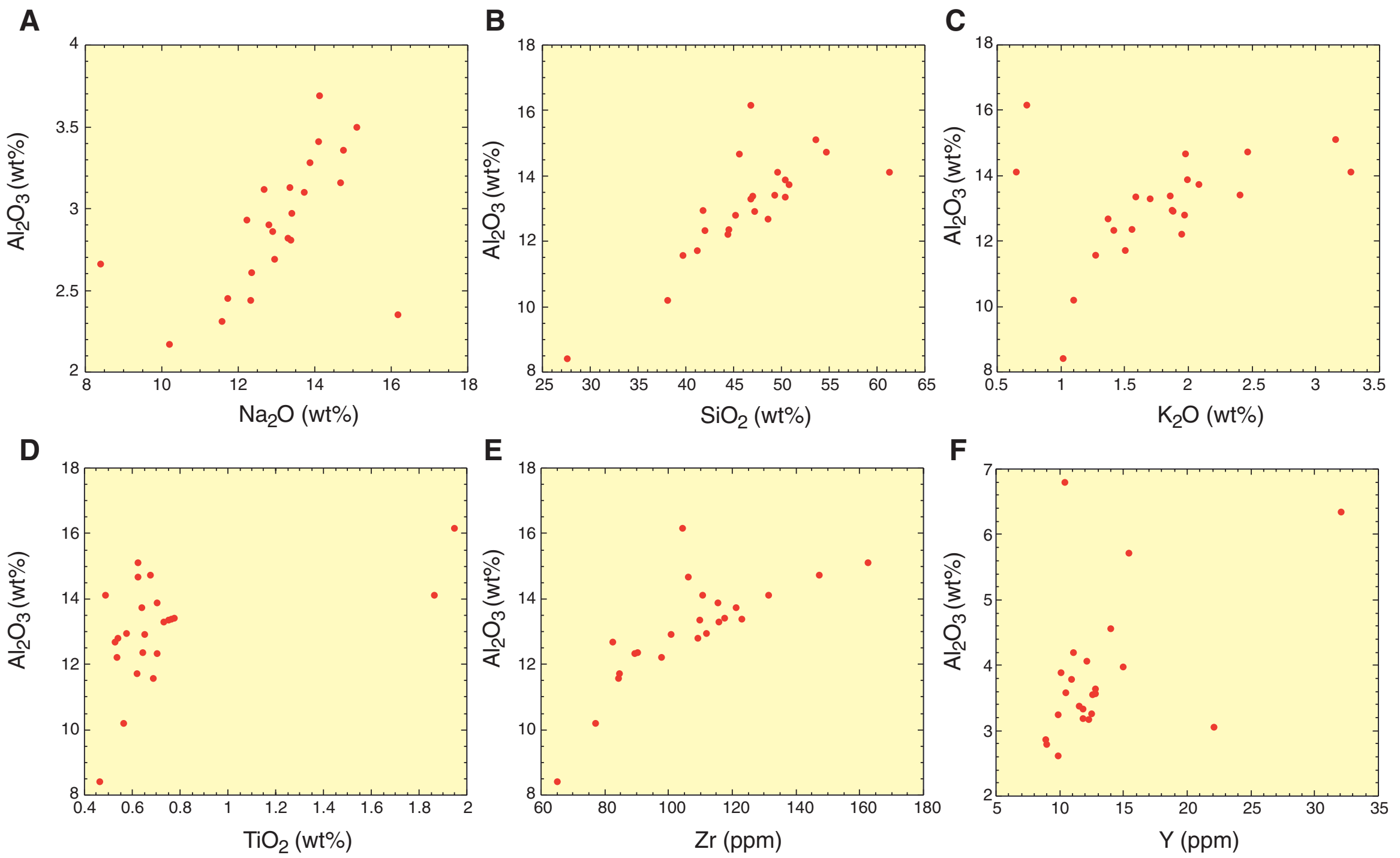
Figure F9 (continued). G. $\mathrm{MgO}$ vs. Cr. $\mathrm{H} . \mathrm{MgO}$ vs. Ni. I. $\mathrm{MgO}$ vs. Cu. J. $\mathrm{MgO}$ vs. Zn. K. $\mathrm{Fe}_{2} \mathrm{O}_{3}$ vs. MnO. L. Cr vs. Ni.
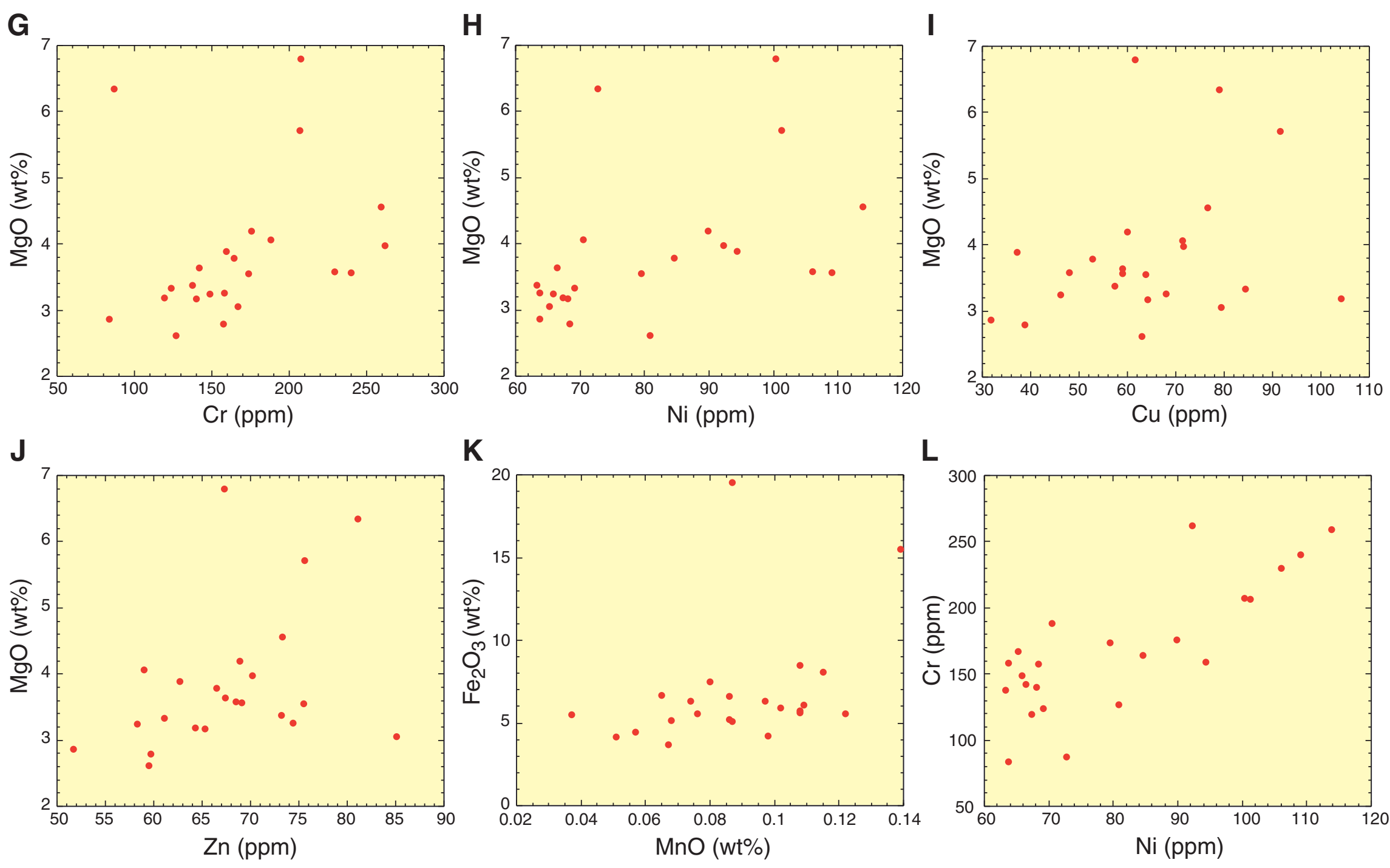
Figure $\mathbf{F 9}$ (continued). M. $\mathrm{Fe}_{2} \mathrm{O}_{3}$ vs. V. N. $\mathrm{K}_{2} \mathrm{O}$ vs. Rb. O. $\mathrm{CaO}$ vs. Sr. P. $\mathrm{MnO}$ vs. Ba.
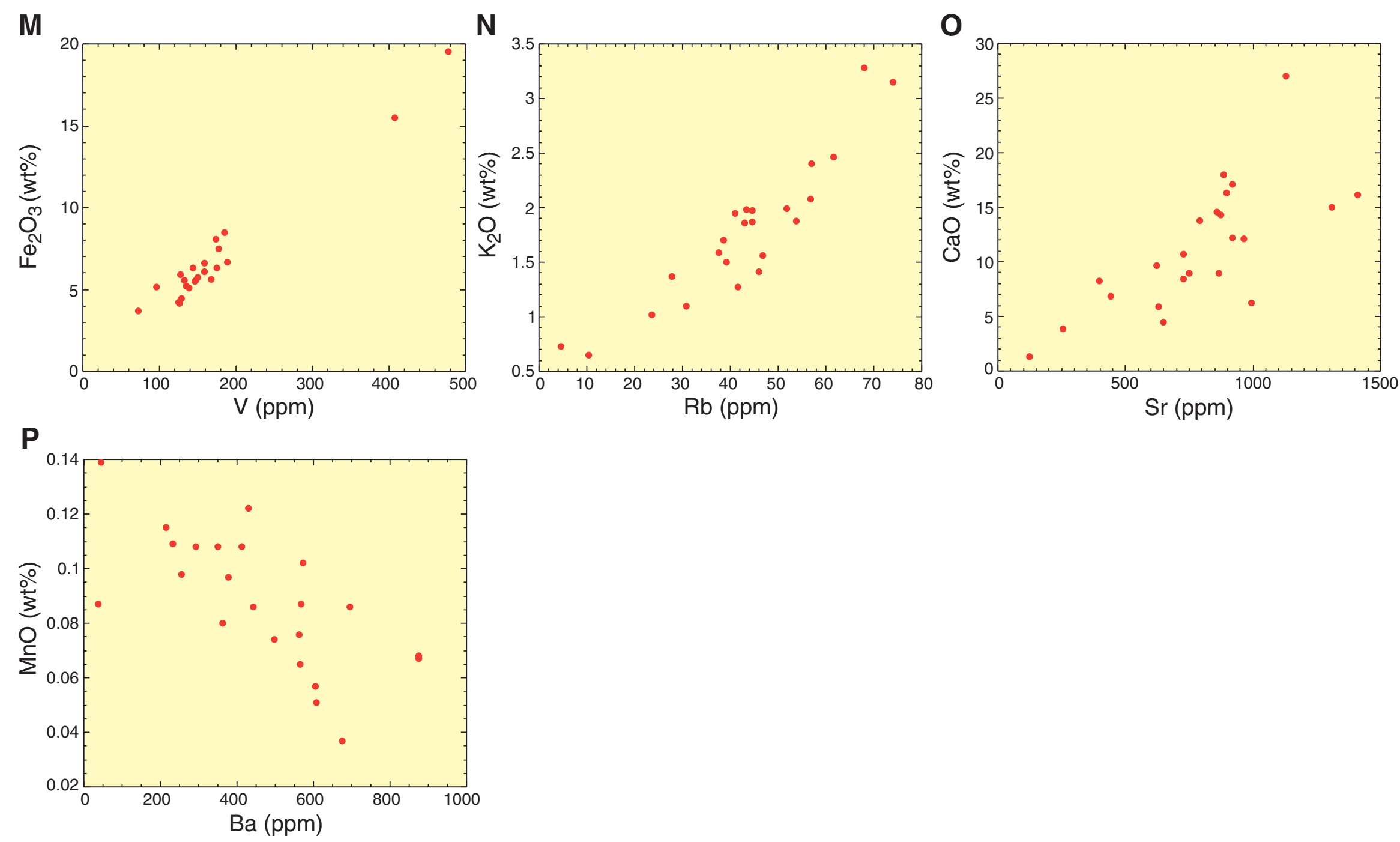
Figure F10. Geochemical variation plots for Site 1108. A. $\mathrm{Al}_{2} \mathrm{O}_{3}$ vs. $\mathrm{K}_{2} \mathrm{O}$. B. $\mathrm{MgO}$ vs. Ni. C. Ni vs. Cu.
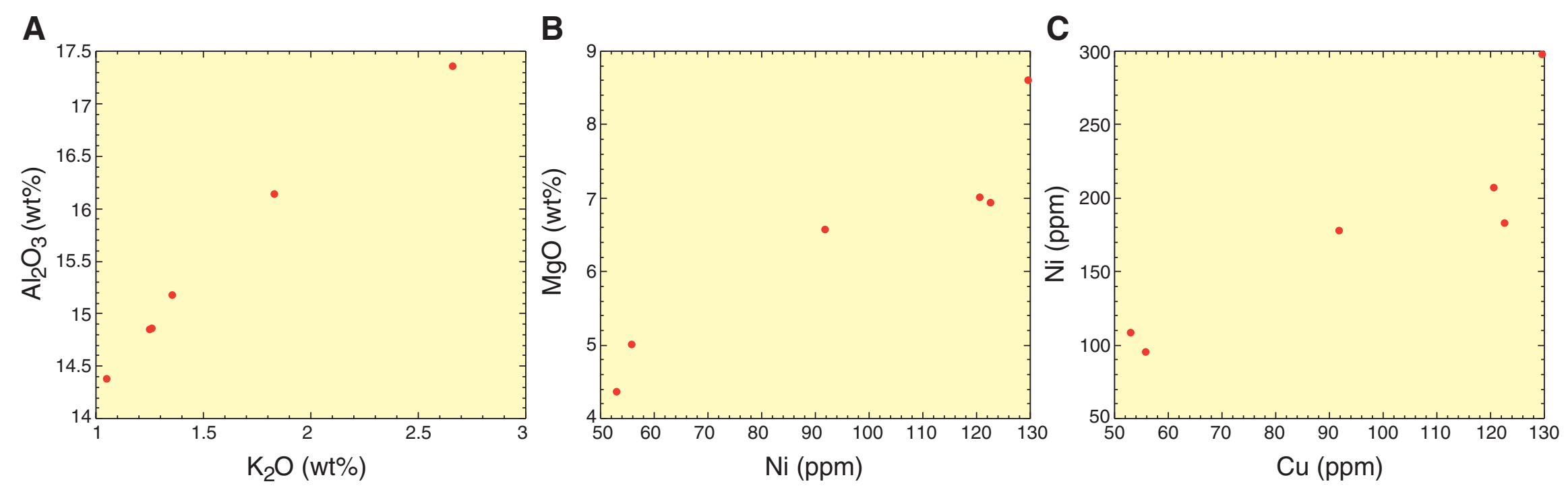
Figure F11. Summary of the sedimentary successions drilled on the southern margin of the Woodlark rift (modified after Taylor, Huchon, Klaus et al., 1999).

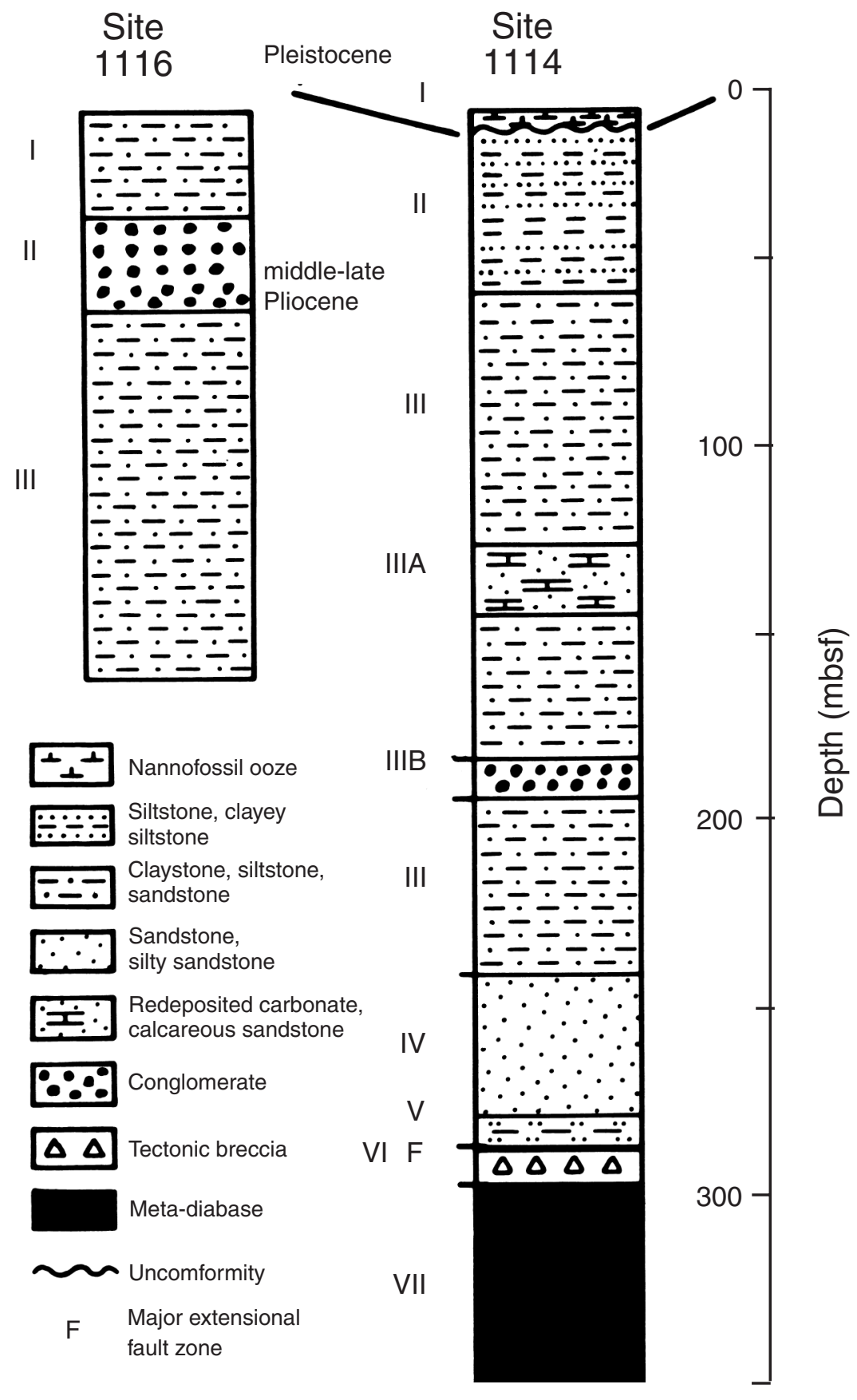


Figure F12. Geochemical variation plots for all sites analyzed (Sites 1108, 1109, 1114, 1116, and 1118). A. $\mathrm{Al}_{2} \mathrm{O}_{3}$ vs. $\mathrm{CaO}$. B. $\mathrm{Al}_{2} \mathrm{O}_{3}$ vs. $\mathrm{TiO}_{2}$. C. $\mathrm{Al}_{2} \mathrm{O}_{3}$ vs. $\mathrm{K}_{2} \mathrm{O}$. D. $\mathrm{Al}_{2} \mathrm{O}_{3}$ vs. $\mathrm{Na}_{2} \mathrm{O}$. E. $\mathrm{Al}_{2} \mathrm{Os}$ vs. $\mathrm{Fe}_{2} \mathrm{O}_{3}$. F. $\mathrm{Al}_{2} \mathrm{O}_{3}$ vs. $\mathrm{MgO}$.

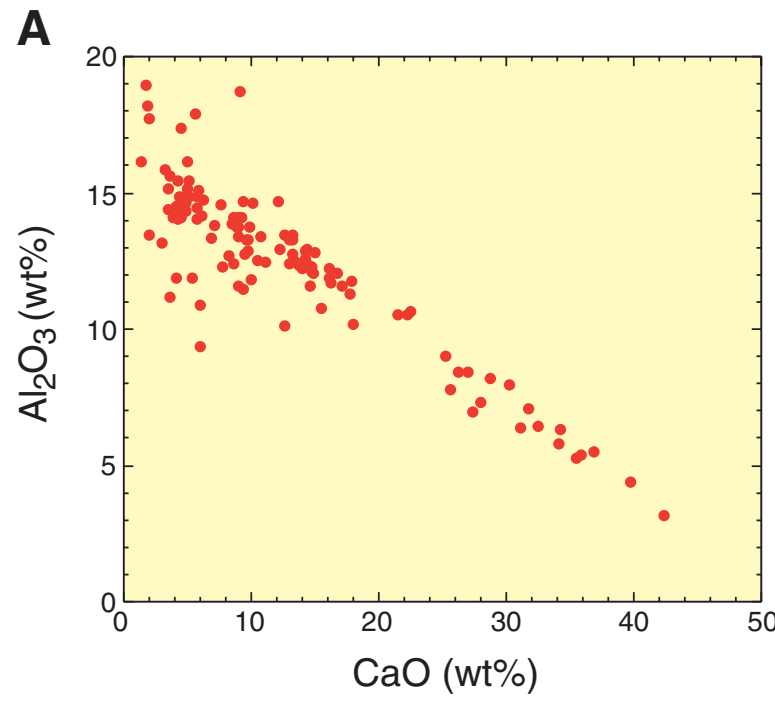

D

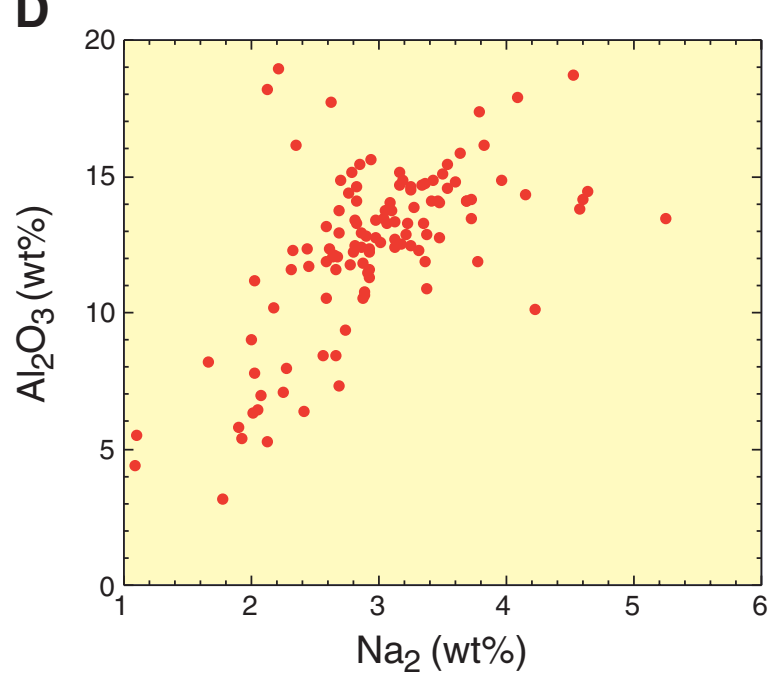

B

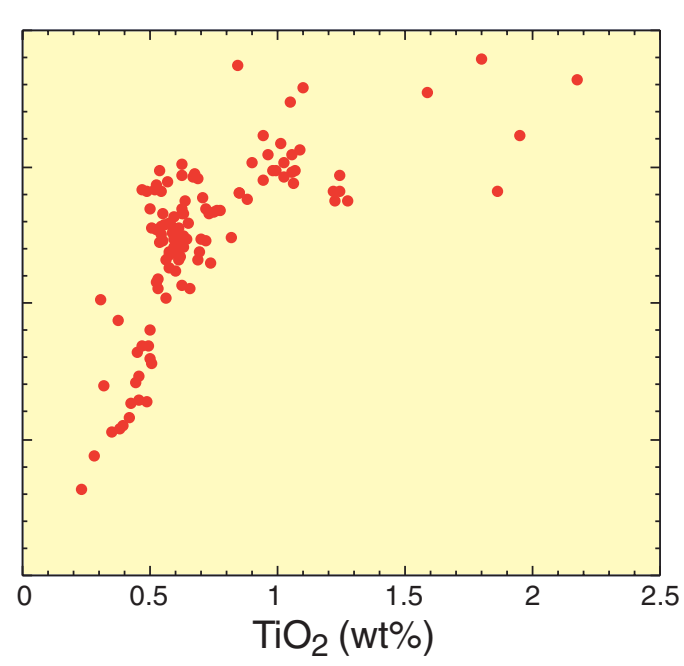

E

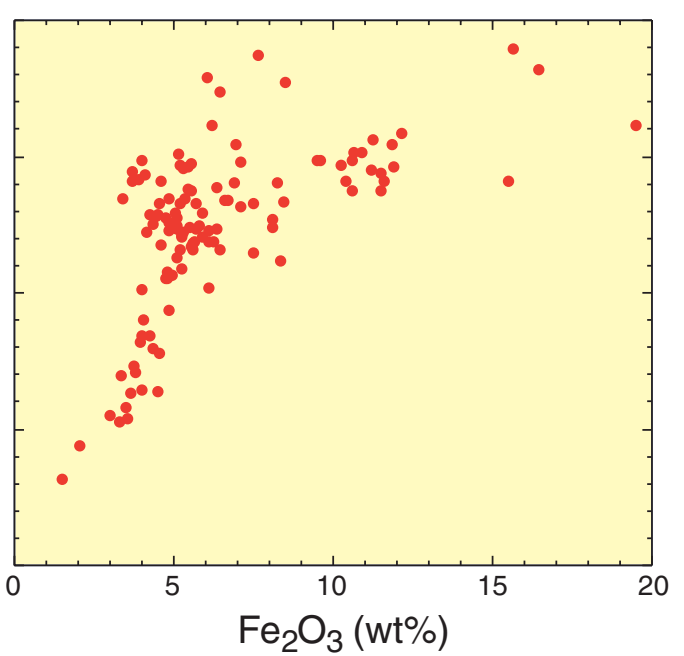

C

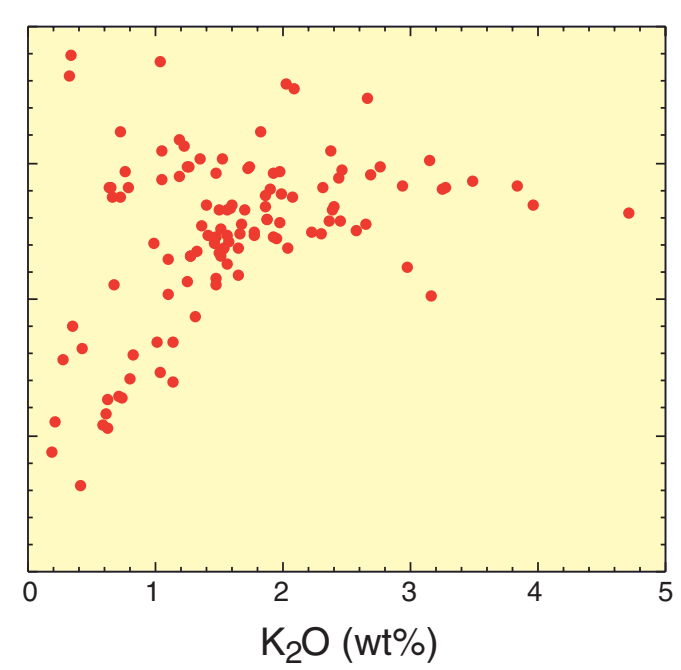

$\mathbf{F}$

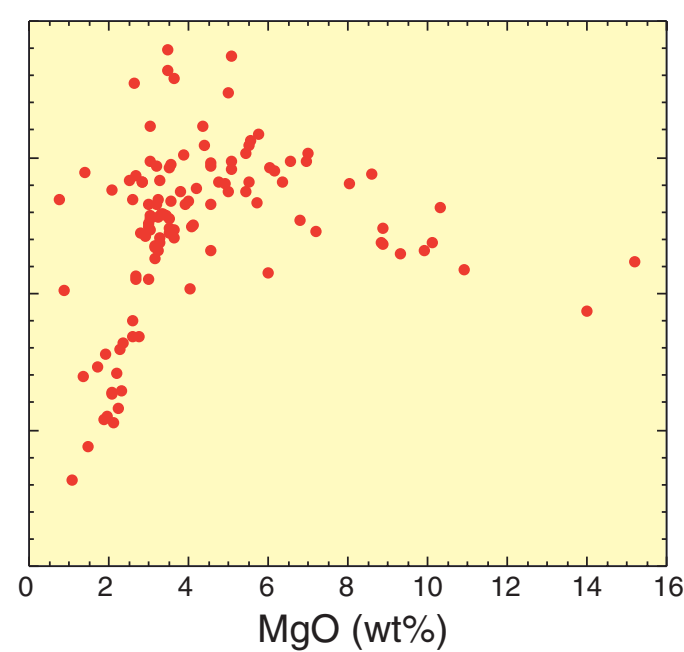


Figure F13. Inferred paleocurrent directions at different stages in the regional tectonic evolution. See "Basinwide Trends," p. 18 for discussion (Robertson et al., 2001). Not palinspastically restored.

late Pliocene - Pleistocene
late Miocene


A.H.F. ROBERTSON AND T.R. SHARP

MiXed VolCaNogenic/TERRIgenous Hemipelagic SEDIMENTS

Table T1. X-ray diffraction analysis of selected samples.

\begin{tabular}{|c|c|c|c|}
\hline $\begin{array}{l}\text { Core, section, } \\
\text { interval }(\mathrm{cm})\end{array}$ & $\begin{array}{c}\text { Major } \\
\text { component }\end{array}$ & $\begin{array}{l}\text { Moderately } \\
\text { abundant }\end{array}$ & $\begin{array}{c}\text { Minor } \\
\text { component }\end{array}$ \\
\hline \multicolumn{4}{|l|}{ 180-1108B- } \\
\hline 20R-1, 97-100 & Qtz, Alb & Smect, Kaol, Calc & III, Pyr \\
\hline $32 \mathrm{R}-3,82-84$ & Qtz, Alb & Smect, Kaol, Calc & III, Pyr \\
\hline \multicolumn{4}{|l|}{ 180-1109B- } \\
\hline \multicolumn{4}{|l|}{ 180-1109C- } \\
\hline $12 X-7,42-44$ & Alb, Qtz & Trem, Kaol & \\
\hline $14 X-1,96-98$ & Talc, Alb, Qtz & Trem, Kaol & Clinochry \\
\hline $21 X-C C, 27-29$ & Talc, Alb, Qtz & Cal, Alb, Qtz & Clinochry \\
\hline \multicolumn{4}{|l|}{ 180-1109D- } \\
\hline $7 \mathrm{R}-3,15-17$ & Calc, Alb, Qtz & Smect, Pyr & \\
\hline $12 \mathrm{R}-1,62-64$ & Alb, Qtz & Calc Smect, Kaol & \\
\hline $43 R-2,60-65$ & Smect & Alb, Qtz & \\
\hline \multicolumn{4}{|l|}{ 180-1114A- } \\
\hline 22R-1, 13-14 & Qtz, Alb, Cal & Smect, Kaol & \\
\hline $8 R-1,65-69$ & Qtz, Alb, Smect & Kaol & Calc, Pyr \\
\hline \multicolumn{4}{|l|}{ 180-1115B- } \\
\hline $4 \mathrm{H}-3,1-3$ & Calc & Qtz & Alb, Arag, Kaol, Pyr \\
\hline $9 \mathrm{H}-6,87-89$ & Calc & Qtz & Alb, Arag, Kaol, Pyr \\
\hline $14 \mathrm{H}-4,65-67$ & Calc & Alb, Qtz & Pyr, Kaol \\
\hline \multicolumn{4}{|l|}{ 180-1115C- } \\
\hline 2R-4, 69-72 & Qtz, Alb, Calc & Phlog, Trem, Pyr & \\
\hline $32 \mathrm{R}-1,43-45$ & Smect, Alb & Qtz, Hem, Calc & \\
\hline $42 \mathrm{R}-4,67-71$ & Smect, Alb, Calc & Qtz, Pyr, Kaol & Heul \\
\hline \multicolumn{4}{|l|}{ 180-1116A- } \\
\hline 3R-CC, 15-18 & Smect, Alb & Calc, Kaol & Pyr \\
\hline 18R-1, 77-79 & Alb, Smect & Calc, Qtz & Pyr \\
\hline \multicolumn{4}{|l|}{$180-1118 \mathrm{~A}-$} \\
\hline $38 R-5,16-19$ & Calc, Qtz & Alb, Smect & Kaol \\
\hline $65 \mathrm{R}-2,29-31$ & Qtz, Smect & Alb, Calc & Kaol, Trem, III, Pyr \\
\hline
\end{tabular}

Notes: Qtz = quartz, Alb = albite, Smect = smectite, Calc = calcite, Talc = talc, Trem $=$ tremolite, $\mathrm{Kaol}=$ kaolinite, $\mathrm{Pyr}=$ pyrite, $\mathrm{Phlog}=$ phlogopite, $\mathrm{Hem}=$ hematite, $\mathrm{III}=$ illite, Arag $=$ aragonite, Clinochry $=$ clinochrysotile, Heul $=$ heulandite. Major component $=$ Large well defined reflection peaks, Moderately abundant $=$ Well defined but relatively small reflection peaks, Minor component $=$ Reflection peaks only just recognizable. 
Table T2. X-ray fluorescence analysis of major elements and trace elements, Site 1115. (Continued on next two pages.)

\begin{tabular}{|c|c|c|c|c|c|c|c|c|c|c|c|c|c|c|c|c|c|c|c|}
\hline $\begin{array}{l}\text { Core, section, } \\
\text { interval }(\mathrm{cm}) \text { : }\end{array}$ & $\begin{array}{l}1 \mathrm{H}-5 \\
89-91\end{array}$ & $\begin{array}{l}3 \mathrm{H}-1, \\
33-35\end{array}$ & $\begin{array}{c}4 \mathrm{H}-3 \\
1-3\end{array}$ & $\begin{array}{l}7 \mathrm{H}-1, \\
49-51\end{array}$ & $\begin{array}{l}8 \mathrm{H}-1 \\
63-65\end{array}$ & $\begin{array}{l}9 \mathrm{H}-6, \\
87-89\end{array}$ & $\begin{array}{c}11 \mathrm{H}-2 \\
125-127\end{array}$ & $\begin{array}{c}12 \mathrm{H}-4 \\
138-139\end{array}$ & $\begin{array}{c}13 \mathrm{H}-6 \\
131-133\end{array}$ & $\begin{array}{l}14 \mathrm{H}-4, \\
65-67\end{array}$ & $\begin{array}{c}15 \mathrm{H}-4 \\
111-113\end{array}$ & $\begin{array}{c}17 \mathrm{H}-5 \\
140-142\end{array}$ & $\begin{array}{l}18 \mathrm{H}-1 \\
54-56\end{array}$ & $\begin{array}{c}18 \mathrm{H}-3, \\
0-3\end{array}$ & $\begin{array}{l}19 \mathrm{H}-1, \\
63-65\end{array}$ & $\begin{array}{c}20 \mathrm{H}-3 \\
147-149\end{array}$ & $\begin{array}{l}22 \mathrm{H}-1, \\
33-35\end{array}$ & $\begin{array}{c}27 X-3 \\
114-116\end{array}$ & $\begin{array}{l}26 X-4 \\
63-65\end{array}$ \\
\hline Depth $(\mathrm{cm})$ : & 6.89 & 17.03 & 29.21 & 55.19 & 64.83 & 82.07 & 95.45 & 108.08 & 120.51 & 126.35 & 136.31 & 157.1 & 159.86 & 162.2 & 169.3 & 182.67 & 193.53 & 220.34 & 240.53 \\
\hline \multicolumn{20}{|l|}{ Oxides (wt\%): } \\
\hline $\mathrm{SiO}_{2}$ & 10.90 & 64.48 & 50.11 & 30.88 & 18.82 & 20.99 & 17.87 & 19.41 & 22.14 & 32.57 & 23.88 & 56.23 & 34.69 & 48.83 & 28.21 & 59.33 & 33.49 & 38.23 & 37.79 \\
\hline $\mathrm{Al}_{2} \mathrm{O}_{3}$ & 3.18 & 13.48 & 10.13 & 6.97 & 5.79 & 6.45 & 5.25 & 6.30 & 7.07 & 10.67 & 7.94 & 13.81 & 10.53 & 13.44 & 9.02 & 14.44 & 10.54 & 11.29 & 10.76 \\
\hline $\mathrm{Fe}_{2} \mathrm{O}_{3}$ & 1.49 & 3.38 & 3.98 & 3.33 & 3.48 & 4.00 & 3.30 & 3.63 & 3.82 & 4.95 & 4.35 & 5.43 & 4.77 & 4.87 & 4.03 & 3.69 & 4.81 & 5.12 & 4.82 \\
\hline $\mathrm{MgO}$ & 1.07 & 0.78 & 0.88 & 1.36 & 2.22 & 2.32 & 2.13 & 2.08 & 2.18 & 2.68 & 2.27 & 2.10 & 2.69 & 2.62 & 2.59 & 1.40 & 2.98 & 3.15 & 6.02 \\
\hline $\mathrm{CaO}$ & 42.41 & 1.94 & 12.66 & 27.40 & 34.17 & 32.52 & 35.48 & 34.21 & 31.73 & 22.49 & 30.25 & 7.11 & 22.28 & 12.60 & 25.20 & 5.78 & 21.46 & 17.74 & 15.55 \\
\hline $\mathrm{Na}_{2} \mathrm{O}$ & 1.77 & 5.25 & 4.23 & 2.07 & 1.90 & 2.05 & 2.12 & 2.01 & 2.25 & 2.89 & 2.27 & 4.57 & 2.59 & 3.72 & 2.00 & 4.64 & 2.88 & 2.93 & 2.89 \\
\hline $\mathrm{K}_{2} \mathrm{O}$ & 0.417 & 3.968 & 3.164 & 1.140 & 0.611 & 0.712 & 0.625 & 0.621 & 0.804 & 1.256 & 0.828 & 1.862 & 0.676 & 1.404 & 0.356 & 2.436 & 1.476 & 1.558 & 1.470 \\
\hline $\mathrm{TiO}_{2}$ & 0.230 & 0.502 & 0.304 & 0.320 & 0.419 & 0.456 & 0.353 & 0.428 & 0.446 & 0.622 & 0.497 & 0.884 & 0.655 & 0.719 & 0.502 & 0.571 & 0.531 & 0.577 & 0.524 \\
\hline $\mathrm{MnO}$ & 0.046 & 0.092 & 0.080 & 0.082 & 0.076 & 0.099 & 0.103 & 0.102 & 0.129 & 0.097 & 0.097 & 0.107 & 0.116 & 0.085 & 0.076 & 0.066 & 0.092 & 0.076 & 0.077 \\
\hline $\mathrm{P}_{2} \mathrm{O}_{5}$ & 0.125 & 0.092 & 0.069 & 0.111 & 0.130 & 0.182 & 0.138 & 0.187 & 0.175 & 0.281 & 0.192 & 0.188 & 0.218 & 0.199 & 0.182 & 0.162 & 0.209 & 0.200 & 0.200 \\
\hline LOI & 37.87 & 5.83 & 14.71 & 25.74 & 31.80 & 29.97 & 31.70 & 30.61 & 28.97 & 21.50 & 27.54 & 7.69 & 20.18 & 11.39 & 27.25 & 6.90 & 21.69 & 18.61 & 19.36 \\
\hline Total & 99.51 & 99.79 & 100.32 & 99.40 & 99.42 & 99.75 & 99.07 & 99.59 & 99.71 & 100.01 & 100.11 & 99.98 & 99.40 & 99.88 & 99.42 & 99.42 & 100.16 & 99.48 & 99.46 \\
\hline \multicolumn{20}{|c|}{ Trace elements (ppm): } \\
\hline $\mathrm{Ba}$ & 373.8 & 334.8 & 373.8 & 195.1 & 269.4 & 208.9 & 288.5 & 245.1 & 284.4 & 269.5 & 253.2 & 410.9 & 246.6 & 403.3 & 359.7 & 501.5 & 322.4 & 573.7 & 393 \\
\hline V & 59.5 & 78.8 & 59.5 & 43.1 & 113.1 & 72.6 & 119.9 & 128.3 & 102.9 & 125.5 & 125.3 & 137.6 & 128.9 & 99.7 & 131.8 & 101.6 & 106.7 & 57.6 & 126.6 \\
\hline La & 6.5 & 6.5 & 33.8 & 10.6 & 27.0 & 9.1 & 7.2 & 6.4 & 10.7 & 9.6 & 16.2 & 11.5 & 13.0 & 13.9 & 16.2 & 13.0 & 16.0 & 10.3 & 13.1 \\
\hline $\mathrm{Ce}$ & 17 & 17.0 & 85.9 & 24.6 & 65.7 & 22.9 & 23.1 & 19.5 & 26.0 & 32.1 & 45.2 & 30.4 & 40.5 & 40.0 & 42.5 & 33.7 & 40.8 & 35.4 & 30.1 \\
\hline $\mathrm{Nd}$ & 9 & 9.0 & 42.1 & 12.9 & 32.4 & 11.5 & 13.1 & 10.5 & 14.7 & 15.6 & 22.2 & 15.9 & 23.0 & 19.5 & 20.8 & 17.2 & 19.5 & 15.7 & 13.2 \\
\hline $\mathrm{Cr}$ & 55 & 88.8 & 55 & 22.1 & 121.4 & 69.3 & 144.4 & 129.5 & 118.2 & 117.8 & 117.6 & 119.2 & 125.8 & 20.2 & 103.8 & 78.7 & 111.4 & 14.9 & 119.7 \\
\hline $\mathrm{Ni}$ & 42.6 & 51 & 42.6 & 30.6 & 92 & 56.3 & 111.5 & 107.7 & 98.7 & 75.7 & 76.7 & 89.3 & 78.8 & 38.4 & 73 & 68 & 79.3 & 24.7 & 75.7 \\
\hline $\mathrm{Cu}$ & 48 & 47.7 & 48 & 21.6 & 58.4 & 40.6 & 64.1 & 71.5 & 59 & 64.9 & 62.5 & 71.1 & 63.8 & 16.1 & 62.9 & 43.8 & 50.1 & 22.7 & 63.1 \\
\hline $\mathrm{Zn}$ & 34.3 & 38.2 & 34.3 & 88.9 & 51.7 & 71.5 & 53.4 & 66.7 & 42.3 & 55.5 & 54.9 & 65 & 50.1 & 69.8 & 58.1 & 59.5 & 51.5 & 33.6 & 58.9 \\
\hline $\mathrm{Pb}$ & 4 & 5.9 & 4 & 18.7 & 4 & 13.9 & 6.4 & 8.1 & 6.2 & 9.5 & 10.5 & 12.7 & 9 & 13.5 & 10.6 & 14.1 & 11.6 & 8.7 & 13.6 \\
\hline $\mathrm{Rb}$ & 12.5 & 12.5 & 95.1 & 19.4 & 55.5 & 19.9 & 21.2 & 17.1 & 17.8 & 22.4 & 29.6 & 19.4 & 36.6 & 27.9 & 37.1 & 26.2 & 35.4 & 33.1 & 40.7 \\
\hline $\mathrm{Sr}$ & 2258.1 & 2258.1 & 112.4 & 1463.0 & 1490.0 & 1758.9 & 1777.8 & 1723.4 & 1688.4 & 1342.2 & 1139.0 & 1247.7 & 397.6 & 1023.2 & 723.6 & 1084.2 & 264.6 & 1046.7 & 991.2 \\
\hline Y & 8.6 & 8.6 & 58.0 & 12.3 & 29.8 & 13.2 & 12.2 & 9.8 & 11.4 & 11.4 & 14.6 & 10.8 & 33.4 & 14.4 & 20.0 & 9.8 & 14.0 & 9.5 & 9.8 \\
\hline $\mathrm{Zr}$ & 20.9 & 20.9 & 545.9 & 47.0 & 265.3 & 45.9 & 45.8 & 46.7 & 47.3 & 66.7 & 118.2 & 71.0 & 215.0 & 104.0 & 156.0 & 77.9 & 133.6 & 90.0 & 91.0 \\
\hline $\mathrm{Nb}$ & 1.4 & 1.5 & 15.1 & 2.5 & 9.3 & 2.4 & 2.6 & 2.4 & 2.5 & 2.7 & 4.5 & 3.6 & 4.0 & 3.5 & 4.2 & 2.8 & 2.5 & 3.3 & 3.5 \\
\hline
\end{tabular}

Note: $\mathrm{LOI}=$ loss on ignition . 
Table T2 (continued).

\begin{tabular}{|c|c|c|c|c|c|c|c|c|c|c|c|c|c|c|c|c|c|c|c|}
\hline $\begin{array}{l}\text { Core, section, } \\
\text { interval }(\mathrm{cm}) \text { : }\end{array}$ & $\begin{array}{l}29 X-7 \\
21-23\end{array}$ & $\begin{array}{l}27 X-4 \\
62-64\end{array}$ & $\begin{array}{l}30 \times-1 \\
62-64\end{array}$ & $\begin{array}{l}31 X-1 \\
30-32\end{array}$ & $\begin{array}{c}3 \mathrm{R}-1 \\
20-22\end{array}$ & $\begin{array}{l}2 \mathrm{R}-4 \\
69-72\end{array}$ & $\begin{array}{l}5 \mathrm{R}-1 \\
39-41\end{array}$ & $\begin{array}{l}\text { 7R-1, } \\
79-81\end{array}$ & $\begin{array}{c}9 R-4, \\
34-36\end{array}$ & $\begin{array}{c}\text { 10R-4, } \\
113-115\end{array}$ & $\begin{array}{l}11 \mathrm{R}-1, \\
14-16\end{array}$ & $\begin{array}{l}13 \mathrm{R}-1, \\
77-79\end{array}$ & $\begin{array}{l}14 \mathrm{R}-1 \\
54-56\end{array}$ & $\begin{array}{l}17 \mathrm{R}-2 \\
52-54\end{array}$ & $\begin{array}{l}18 \mathrm{R}-2, \\
64-66\end{array}$ & $\begin{array}{l}22 \mathrm{R}-5 \\
13-14\end{array}$ & $\begin{array}{c}24 \mathrm{R}-1 \\
111-113\end{array}$ & $\begin{array}{l}30 \mathrm{R}-4, \\
57-59\end{array}$ & $\begin{array}{l}32 \mathrm{R}-1 \\
43-45\end{array}$ \\
\hline Depth $(\mathrm{cm})$ : & 273.51 & 250.12 & 274.52 & 283.82 & 302.7 & 269.88 & 322.09 & 371.79 & 364.09 & 375.14 & 379.24 & 398.87 & 408.24 & 483.21 & 488.21 & 489.89 & 504.91 & 565.37 & 581.03 \\
\hline \multicolumn{20}{|l|}{ Oxides (wt\%): } \\
\hline $\mathrm{SiO}_{2}$ & 51.55 & 44.05 & 48.26 & 45.29 & 45.19 & 58.68 & 43.58 & 45.39 & 44.27 & 43.71 & 42.06 & 43.75 & 40.85 & 48.85 & 51.84 & 44.51 & 49.83 & 56.11 & 53.81 \\
\hline $\mathrm{Al}_{2} \mathrm{O}_{3}$ & 13.26 & 13.44 & 14.60 & 13.26 & 12.73 & 14.85 & 12.12 & 12.47 & 12.57 & 12.33 & 12.07 & 12.20 & 11.78 & 12.46 & 12.74 & 12.86 & 14.54 & 17.70 & 13.15 \\
\hline $\mathrm{Fe}_{2} \mathrm{O}_{3}$ & 4.53 & 5.36 & 5.45 & 5.22 & 5.11 & 4.01 & 5.24 & 5.09 & 4.87 & 5.12 & 5.27 & 5.32 & 4.59 & 5.78 & 4.76 & 4.25 & 5.29 & 8.49 & 7.10 \\
\hline $\mathrm{MgO}$ & 2.98 & 3.25 & 3.53 & 3.19 & 3.04 & 3.06 & 2.90 & 3.00 & 2.99 & 3.04 & 3.27 & 3.54 & 3.16 & 4.07 & 3.51 & 3.45 & 5.09 & 2.65 & 10.31 \\
\hline $\mathrm{CaO}$ & 9.81 & 13.24 & 10.13 & 13.20 & 13.29 & 5.79 & 14.75 & 13.50 & 14.19 & 14.34 & 14.90 & 13.97 & 17.91 & 11.13 & 9.51 & 14.26 & 7.67 & 2.03 & 3.05 \\
\hline $\mathrm{Na}_{2} \mathrm{O}$ & 3.23 & 3.04 & 3.25 & 3.06 & 2.98 & 3.96 & 2.65 & 2.81 & 3.01 & 2.92 & 2.67 & 2.80 & 2.78 & 3.25 & 3.48 & 3.21 & 3.54 & 2.62 & 2.59 \\
\hline $\mathrm{K}_{2} \mathrm{O}$ & 2.388 & 1.603 & 1.929 & 1.562 & 1.679 & 2.758 & 1.573 & 1.778 & 1.517 & 1.772 & 1.462 & 1.468 & 1.327 & 2.231 & 2.655 & 2.362 & 2.688 & 2.086 & 4.714 \\
\hline $\mathrm{TiO}_{2}$ & 0.549 & 0.624 & 0.671 & 0.630 & 0.613 & 0.540 & 0.615 & 0.629 & 0.590 & 0.596 & 0.595 & 0.608 & 0.574 & 0.602 & 0.507 & 0.582 & 0.687 & 1.587 & 0.596 \\
\hline $\mathrm{MnO}$ & 0.059 & 0.066 & 0.057 & 0.069 & 0.066 & 0.063 & 0.059 & 0.063 & 0.064 & 0.067 & 0.065 & 0.062 & 0.057 & 0.073 & 0.052 & 0.032 & 0.050 & 0.053 & 0.083 \\
\hline $\mathrm{P}_{2} \mathrm{O}_{5}$ & 0.205 & 0.181 & 0.204 & 0.197 & 0.204 & 0.216 & 0.201 & 0.210 & 0.190 & 0.176 & 0.196 & 0.170 & 0.186 & 0.176 & 0.161 & 0.196 & 0.309 & 0.032 & 0.531 \\
\hline LOI & 11.34 & 14.64 & 12.13 & 14.45 & 14.53 & 5.50 & 15.75 & 14.46 & 15.20 & 15.75 & 16.46 & 15.58 & 16.20 & 11.54 & 10.24 & 13.99 & 10.03 & 6.50 & 4.10 \\
\hline Total & 99.90 & 99.49 & 100.21 & 100.13 & 99.43 & 99.43 & 99.44 & 99.40 & 99.46 & 99.82 & 99.02 & 99.47 & 99.41 & 100.16 & 99.46 & 99.70 & 99.72 & 99.86 & 100.03 \\
\hline \multicolumn{20}{|c|}{ Trace elements (ppm): } \\
\hline $\mathrm{Ba}$ & 407.1 & 668.6 & 512.5 & 583.8 & 547.4 & 593 & 845.2 & 558 & 671 & 625.6 & 526.8 & 529.3 & 562 & 637.1 & 628.7 & 791.6 & 964.3 & 936.1 & 390 \\
\hline V & 125.1 & 103.2 & 135.4 & 133.5 & 134.3 & 119.1 & 91.2 & 132.5 & 126.9 & 123.2 & 128.1 & 124 & 128.2 & 134.1 & 141.9 & 108.6 & 87.7 & 96.8 & 283.8 \\
\hline La & 11.2 & 13.6 & 15.0 & 17.0 & 13.8 & 21.6 & 14.3 & 10.0 & 16.4 & 20.7 & 14.5 & 17.1 & 16.1 & 11.2 & 10.6 & 28.6 & 31.2 & 10.7 & 13.7 \\
\hline $\mathrm{Ce}$ & 29.3 & 35.8 & 38.9 & 40.7 & 40.0 & 42.1 & 35.1 & 38.4 & 38.1 & 36.7 & 37.6 & 39.4 & 35.8 & 38.3 & 34.8 & 70.0 & 70.4 & 28.9 & 34.8 \\
\hline $\mathrm{Nd}$ & 13.7 & 13.7 & 17.7 & 16.6 & 17.7 & 18.2 & 16.2 & 16.3 & 17.7 & 15.7 & 17.2 & 16.2 & 19.1 & 17.7 & 16.5 & 29.2 & 30.2 & 23.8 & 18.3 \\
\hline $\mathrm{Cr}$ & 137.5 & 128.4 & 154.8 & 177.9 & 153.7 & 147.5 & 91.2 & 146.3 & 162.7 & 144.6 & 168.1 & 188.3 & 203.2 & 171.7 & 303.9 & 188 & 145.8 & 179.1 & 924.3 \\
\hline $\mathrm{Ni}$ & 76.9 & 70.6 & 83 & 89.4 & 80.3 & 75.2 & 66 & 68.2 & 83.4 & 76.5 & 84.8 & 99.7 & 105.5 & 81.3 & 99.6 & 82.1 & 60.5 & 76.3 & 124.1 \\
\hline $\mathrm{Cu}$ & 54.5 & 46.1 & 53.4 & 50.8 & 50.6 & 48.6 & 35.2 & 52.7 & 53.8 & 51.5 & 51.5 & 52.2 & 51 & 41.9 & 37 & 31.8 & 31.1 & 33.1 & 65.8 \\
\hline $\mathrm{Zn}$ & 64.4 & 59.8 & 64.1 & 72.2 & 69 & 65.7 & 76.3 & 70.5 & 69 & 68 & 69.9 & 70 & 68.6 & 63.9 & 64.4 & 55.9 & 57.4 & 59.7 & 92.6 \\
\hline $\mathrm{Pb}$ & 15.6 & 20.7 & 18.1 & 18.6 & 19.3 & 20.2 & 29.8 & 17.5 & 23.9 & 22.8 & 21.6 & 26.8 & 25.5 & 20 & 27.7 & 35.3 & 40.2 & 44.4 & 11.4 \\
\hline $\mathrm{Rb}$ & 37.8 & 46.3 & 53.8 & 47.7 & 50.4 & 60.1 & 49.2 & 51.6 & 47.3 & 48.0 & 47.6 & 49.4 & 39.9 & 57.9 & 67.1 & 55.4 & 58.3 & 49.8 & 124.7 \\
\hline $\mathrm{Sr}$ & 715.3 & 787.9 & 720.9 & 889.2 & 900.0 & 839.7 & 956.2 & 982.2 & 1074.0 & 939.0 & 984.4 & 1012.5 & 1212.6 & 1131.3 & 1156.8 & 1704.3 & 1149.0 & 448.9 & 397.0 \\
\hline Y & 9.5 & 10.4 & 12.1 & 10.8 & 9.7 & 10.7 & 11.5 & 9.3 & 10.0 & 9.9 & 8.8 & 9.8 & 9.2 & 9.6 & 8.4 & 8.6 & 10.5 & 29.9 & 13.7 \\
\hline $\mathrm{Zr}$ & 86.6 & 96.0 & 121.3 & 108.4 & 111.2 & 123.5 & 103.3 & 113.6 & 108.0 & 108.4 & 109.5 & 114.9 & 108.7 & 112.8 & 110.3 & 214.4 & 229.5 & 104.5 & 146.2 \\
\hline $\mathrm{Nb}$ & 3.4 & 3.5 & 3.9 & 3.8 & 3.7 & 4.4 & 3.4 & 3.9 & 3.7 & 4.1 & 4.0 & 4.0 & 3.4 & 3.6 & 3.6 & 5.2 & 6.6 & 5.1 & 4.7 \\
\hline
\end{tabular}


Table T2 (continued).

\begin{tabular}{|c|c|c|c|c|c|c|c|c|}
\hline $\begin{array}{l}\text { Core, section, } \\
\text { interval }(\mathrm{cm}) \text { : }\end{array}$ & $\begin{array}{l}34 \mathrm{R}-1 \\
50-52\end{array}$ & $\begin{array}{l}36 \mathrm{R}-1 \\
86-88\end{array}$ & $\begin{array}{l}\text { 40R-1, } \\
78-79\end{array}$ & $\begin{array}{l}40 \mathrm{R}-3 \\
83-84\end{array}$ & $\begin{array}{l}42 \mathrm{R}-4 \\
67-71\end{array}$ & $\begin{array}{l}44 \mathrm{R}-1 \\
30-32\end{array}$ & $\begin{array}{l}48 \mathrm{R}-1 \\
44-46\end{array}$ & $\begin{array}{l}50 \mathrm{R}-1 \\
27-29\end{array}$ \\
\hline Depth $(\mathrm{cm})$ : & 600.3 & 619.96 & 659.3 & 661.63 & 681.58 & 696.8 & 735.54 & 754.57 \\
\hline \multicolumn{9}{|l|}{ Oxides (wt\%): } \\
\hline $\mathrm{SiO}_{2}$ & 46.69 & 48.21 & 53.12 & 45.82 & 45.82 & 46.50 & 46.01 & 44.91 \\
\hline $\mathrm{Al}_{2} \mathrm{O}_{3}$ & 12.38 & 11.18 & 14.12 & 13.76 & 14.10 & 14.66 & 14.11 & 13.72 \\
\hline $\mathrm{Fe}_{2} \mathrm{O}_{3}$ & 8.08 & 8.34 & 4.58 & 11.52 & 10.39 & 10.26 & 11.60 & 10.59 \\
\hline $\mathrm{MgO}$ & 8.88 & 15.18 & 2.86 & 5.42 & 4.77 & 4.56 & 5.50 & 5.02 \\
\hline $\mathrm{CaO}$ & 8.66 & 3.63 & 8.99 & 8.84 & 9.27 & 9.37 & 8.63 & 9.82 \\
\hline $\mathrm{Na}_{2} \mathrm{O}$ & 3.13 & 2.03 & 3.69 & 2.69 & 3.46 & 3.34 & 2.83 & 3.05 \\
\hline $\mathrm{K}_{2} \mathrm{O}$ & 2.305 & 2.973 & 2.309 & 0.668 & 0.792 & 0.758 & 0.634 & 0.721 \\
\hline $\mathrm{TiO}_{2}$ & 0.821 & 0.597 & 0.542 & 1.272 & 1.218 & 1.243 & 1.242 & 1.225 \\
\hline $\mathrm{MnO}$ & 0.107 & 0.122 & 0.064 & 0.103 & 0.119 & 0.141 & 0.184 & 0.123 \\
\hline $\mathrm{P}_{2} \mathrm{O}_{5}$ & 0.364 & 0.525 & 0.199 & 0.121 & 0.115 & 0.128 & 0.126 & 0.109 \\
\hline LOI & 8.47 & 6.67 & 8.97 & 9.27 & 9.35 & 8.56 & 8.59 & 10.18 \\
\hline Total & 99.89 & 99.46 & 99.44 & 99.48 & 99.40 & 99.52 & 99.46 & 99.47 \\
\hline \multicolumn{9}{|c|}{ Trace elements (ppm): } \\
\hline $\mathrm{Ba}$ & 703.8 & 889.7 & 853.1 & 706.8 & 106.4 & 171.9 & 159.7 & 91.8 \\
\hline $\mathrm{V}$ & 138 & 223.8 & 171.3 & 94.4 & 315.7 & 283.3 & 294 & 298.8 \\
\hline La & 8.3 & 7.5 & 16.0 & 7.2 & 3.1 & 2.8 & 1.7 & 1.6 \\
\hline $\mathrm{Ce}$ & 23.9 & 26.0 & 40.8 & 16.7 & 13.9 & 14.3 & 15.8 & 14.0 \\
\hline $\mathrm{Nd}$ & 13.2 & 13.9 & 17.1 & 11.8 & 10.2 & 10.3 & 10.7 & 10.0 \\
\hline $\mathrm{Cr}$ & 195.5 & 505.1 & 458.1 & 110.4 & 278.6 & 260.7 & 272.7 & 259.7 \\
\hline $\mathrm{Ni}$ & 207.5 & 236 & 423.1 & 70.9 & 94.3 & 86.1 & 85.3 & 86.1 \\
\hline $\mathrm{Cu}$ & 109.9 & 79.3 & 103.1 & 36.3 & 106.5 & 103.5 & 95.9 & 122 \\
\hline $\mathrm{Zn}$ & 56.8 & 72.1 & 71.4 & 60 & 91.3 & 87.2 & 88.5 & 85.8 \\
\hline $\mathrm{Pb}$ & 20.9 & 13.7 & 17.1 & 24.7 & 3.7 & 8.1 & 7.8 & 4.9 \\
\hline $\mathrm{Rb}$ & 60.2 & 72.4 & 56.1 & 17.1 & 16.9 & 16.5 & 13.0 & 15.5 \\
\hline $\mathrm{Sr}$ & 569.4 & 322.7 & 1018.9 & 481.8 & 550.8 & 425.1 & 300.3 & 325.2 \\
\hline$Y$ & 14.1 & 12.6 & 9.8 & 20.2 & 18.9 & 19.9 & 20.7 & 23.2 \\
\hline $\mathrm{Zr}$ & 85.1 & 85.9 & 121.4 & 78.5 & 74.0 & 73.6 & 75.3 & 76.5 \\
\hline $\mathrm{Nb}$ & 3.5 & 3.2 & 3.7 & 4.3 & 4.4 & 4.2 & 4.5 & 4.3 \\
\hline
\end{tabular}


Table T3. X-ray fluorescence analysis of major elements and trace elements, Site 1109. (Continued on next page.)

\begin{tabular}{|c|c|c|c|c|c|c|c|c|c|c|c|c|c|c|c|c|c|c|c|}
\hline $\begin{array}{l}\text { Core, section, } \\
\text { interval }(\mathrm{cm}) \text { : }\end{array}$ & $\begin{array}{c}1 \mathrm{H}-1 \\
132-135\end{array}$ & $\begin{array}{c}3 \mathrm{H}-2 \\
86-90\end{array}$ & $\begin{array}{c}4 \mathrm{H}-2 \\
105-107\end{array}$ & $\begin{array}{l}5 \mathrm{H}-2 \\
61-65\end{array}$ & $\begin{array}{r}6 \mathrm{H}-7 \\
2.5-4.5\end{array}$ & $\begin{array}{r}9 \mathrm{H}-5, \\
93-96\end{array}$ & $\begin{array}{l}10 \mathrm{H}-2, \\
43-45\end{array}$ & $\begin{array}{l}11 \mathrm{H}-4, \\
91-93\end{array}$ & $\begin{array}{l}12 X-7 \\
42-44\end{array}$ & $\begin{array}{r}13 X-4 \\
109-110\end{array}$ & $\begin{array}{c}13 X-6 \\
115-116\end{array}$ & $\begin{array}{l}14 X-1 \\
96-98\end{array}$ & $\begin{array}{l}15 X-3 \\
77-79\end{array}$ & $\begin{array}{l}17 \mathrm{X}-\mathrm{CC} \\
12-14\end{array}$ & $\begin{array}{l}18 X-4, \\
89-92\end{array}$ & $\begin{array}{l}20 \mathrm{X}-2 \\
28-30\end{array}$ & $\begin{array}{c}21 X-C C \\
27-29\end{array}$ & $\begin{array}{l}37 X-1, \\
59-61\end{array}$ & $\begin{array}{l}40 X-1 \\
52-54\end{array}$ \\
\hline Depth (mbsf): & 1.33 & 26.92 & 28.95 & 38.01 & 54.42 & 80.83 & 85.33 & 98.31 & 111.82 & 171.59 & 120.65 & 122.56 & 144.58 & 152.92 & 165.49 & 181.08 & 189.17 & 343.69 & 362.72 \\
\hline \multicolumn{20}{|l|}{ Oxides (wt\%): } \\
\hline $\mathrm{SiO}_{2}$ & 28.27 & 26.92 & 21.36 & 17.15 & 26.38 & 28.68 & 52.42 & 57.35 & 53.08 & 52.10 & 44.01 & 53.43 & 44.78 & 58.26 & 45.45 & 53.37 & 57.14 & 50.17 & 45.12 \\
\hline $\mathrm{Al}_{2} \mathrm{O}_{3}$ & 7.77 & 7.33 & 6.40 & 5.36 & 8.21 & 8.42 & 14.07 & 11.90 & 9.36 & 11.90 & 11.49 & 10.89 & 11.57 & 14.18 & 11.83 & 12.29 & 14.36 & 18.71 & 13.28 \\
\hline $\mathrm{Fe}_{2} \mathrm{O}_{3}$ & 4.54 & 3.73 & 4.51 & 3.53 & 3.95 & 3.99 & 6.90 & 5.64 & 4.86 & 6.10 & 7.52 & 5.23 & 6.45 & 3.75 & 5.62 & 4.83 & 4.09 & 7.63 & 5.72 \\
\hline $\mathrm{MgO}$ & 1.92 & 1.71 & 2.08 & 1.87 & 2.37 & 2.78 & 8.05 & 8.86 & 14.00 & 10.12 & 9.33 & 10.92 & 9.92 & 2.53 & 8.87 & 7.20 & 2.66 & 5.09 & 3.90 \\
\hline $\mathrm{CaO}$ & 25.66 & 27.94 & 31.16 & 35.92 & 28.75 & 26.24 & 4.30 & 4.15 & 6.06 & 5.40 & 9.36 & 5.96 & 9.02 & 4.31 & 10.01 & 7.72 & 4.84 & 9.10 & 13.03 \\
\hline $\mathrm{Na}_{2} \mathrm{O}$ & 2.03 & 2.69 & 2.41 & 1.93 & 1.66 & 2.56 & 3.47 & 3.77 & 2.74 & 3.36 & 2.91 & 3.38 & 2.92 & 4.60 & 2.88 & 3.31 & 4.15 & 4.52 & 3.35 \\
\hline $\mathrm{K}_{2} \mathrm{O}$ & 0.272 & 1.036 & 0.739 & 0.587 & 0.428 & 1.142 & 1.904 & 2.036 & 1.307 & 1.652 & 1.106 & 1.645 & 1.270 & 3.834 & 1.520 & 1.928 & 3.486 & 1.041 & 1.505 \\
\hline $\mathrm{TiO}_{2}$ & 0.505 & 0.456 & 0.490 & 0.379 & 0.447 & 0.492 & 0.851 & 0.572 & 0.378 & 0.598 & 0.735 & 0.530 & 0.611 & 0.469 & 0.584 & 0.547 & 0.526 & 0.841 & 0.623 \\
\hline $\mathrm{MnO}$ & 0.095 & 0.110 & 0.125 & 0.079 & 0.106 & 0.094 & 0.086 & 0.074 & 0.067 & 0.078 & 0.113 & 0.067 & 0.118 & 0.089 & 0.111 & 0.082 & 0.080 & 0.106 & 0.081 \\
\hline $\mathrm{P}_{2} \mathrm{O}_{5}$ & 0.133 & 0.135 & 0.130 & 0.123 & 0.234 & 0.190 & 0.169 & 0.121 & 0.168 & 0.158 & 0.160 & 0.166 & 0.162 & 0.136 & 0.167 & 0.149 & 0.129 & 0.349 & 0.202 \\
\hline LOI & 28.34 & 28.15 & 30.72 & 32.09 & 26.86 & 24.90 & 7.72 & 5.41 & 7.66 & 8.16 & 12.75 & 7.29 & 12.67 & 7.77 & 13.18 & 8.30 & 8.00 & 1.97 & 12.97 \\
\hline Total & 99.54 & 100.21 & 100.12 & 99.02 & 99.40 & 99.49 & 99.94 & 99.88 & 99.68 & 99.63 & 99.48 & 99.51 & 99.49 & 99.93 & 100.22 & 99.73 & 99.46 & 99.53 & 99.78 \\
\hline \multicolumn{20}{|c|}{ Trace elements (ppm): } \\
\hline $\mathrm{Ba}$ & 368.8 & 682.6 & 574 & 547.2 & 303.5 & 299.1 & 329.2 & 390.2 & 398.4 & 484.4 & 442.3 & 395.3 & 508.2 & 459.7 & 602.8 & 479.3 & 614 & 808.5 & 658.8 \\
\hline V & 222.4 & 127 & 123.4 & 155.4 & 103.4 & 118.1 & 116.4 & 136.2 & 82.6 & 64.4 & 93.9 & 143.9 & 73.3 & 117.8 & 50 & 100.2 & 88.2 & 51.8 & 215 \\
\hline La & 21.2 & 11.8 & 16.6 & 10.3 & 10.8 & 15.4 & 21.5 & 18.3 & 15.2 & 19.1 & 15.6 & 15.9 & 15.9 & 37.6 & 16.2 & 14.8 & 38.4 & 19.4 & 10.7 \\
\hline $\mathrm{Ce}$ & 46.9 & 28.3 & 21.0 & 22.7 & 38.9 & 34.3 & 60.6 & 44.2 & 30.7 & 45.9 & 41.9 & 41.0 & 44.0 & 77.5 & 44.7 & 38.6 & 82.5 & 50.7 & 36.7 \\
\hline $\mathrm{Nd}$ & 26.7 & 15.8 & 15.8 & 14.0 & 17.6 & 16.3 & 26.5 & 21.3 & 14.6 & 22.4 & 20.6 & 18.9 & 19.8 & 34.8 & 20.1 & 18.1 & 37.6 & 27.5 & 15.5 \\
\hline $\mathrm{Cr}$ & 379.1 & 86.9 & 73.4 & 103 & 111.7 & 117 & 117 & 514.8 & 596.7 & 1168.9 & 747.8 & 662.9 & 959.8 & 649.4 & 97.6 & 517.2 & 633.3 & 128.9 & 93.3 \\
\hline $\mathrm{Ni}$ & 114.8 & 85 & 55.4 & 94.5 & 98.4 & 86.2 & 83.7 & 425.1 & 465.1 & 741.4 & 594.7 & 476.5 & 654.7 & 591.9 & 112.9 & 515.3 & 368.5 & 110.4 & 67.5 \\
\hline $\mathrm{Cu}$ & 73.8 & 72.9 & 71.4 & 94.9 & 59.2 & 59.6 & 54.4 & 49.8 & 25.6 & 16.8 & 35.2 & 66.8 & 20.1 & 53.5 & 18.3 & 48 & 27.7 & 23.8 & 56.1 \\
\hline $\mathrm{Zn}$ & 69 & 88.9 & 75.4 & 78.8 & 51.6 & 52.2 & 55.9 & 81.2 & 62.2 & 49.8 & 71.4 & 80.2 & 56.5 & 45.6 & 67.9 & 69.4 & 55 & 74 & 64.1 \\
\hline $\mathrm{Pb}$ & 13.9 & 11.7 & 8.5 & 11.2 & 7.4 & 10.7 & 11.9 & 20.8 & 20.2 & 22.5 & 24.2 & 27.4 & 23 & 17.4 & 20.3 & 23.5 & 24.5 & 20.7 & 20.8 \\
\hline $\mathrm{Rb}$ & 7.0 & 3.5 & 3.4 & 2.3 & 3.8 & 3.4 & 8.6 & 6.9 & 3.5 & 6.2 & 5.6 & 5.5 & 3.1 & 15.4 & 5.7 & 4.4 & 13.9 & 3.8 & 3.6 \\
\hline $\mathrm{Sr}$ & 839.9 & 1004.9 & 1129.8 & 1586.0 & 1302.3 & 1245.0 & 399.3 & 456.1 & 792.4 & 520.3 & 521.4 & 626.6 & 397.7 & 311.7 & 817.0 & 818.1 & 354.9 & 1792.7 & 866.3 \\
\hline Y & 20.4 & 28.5 & 19.0 & 19.8 & 13.3 & 10.0 & 11.9 & 22.6 & 19.7 & 10.7 & 17.5 & 18.6 & 14.6 & 8.5 & 29.3 & 12.3 & 10.9 & 31.3 & 16.2 \\
\hline $\mathrm{Zr}$ & 160.6 & 207.0 & 85.8 & 58.7 & 43.2 & 85.1 & 89.3 & 235.2 & 200.1 & 130.0 & 179.9 & 135.2 & 162.5 & 88.1 & 382.7 & 150.8 & 128.4 & 370.3 & 64.7 \\
\hline $\mathrm{Nb}$ & 7.0 & 3.5 & 3.4 & 2.3 & 3.8 & 3.4 & 8.6 & 6.9 & 3.5 & 6.2 & 5.6 & 5.5 & 3.1 & 15.4 & 5.7 & 4.4 & 13.9 & 3.8 & 3.6 \\
\hline
\end{tabular}

Note: $\mathrm{LOI}=$ loss on ignition . 
Table T3 (continued).

\begin{tabular}{|c|c|c|c|c|c|c|c|c|}
\hline $\begin{array}{l}\text { Core, section, } \\
\text { interval }(\mathrm{cm}) \text { : }\end{array}$ & $\begin{array}{l}41 \mathrm{R}-3 \\
55-57\end{array}$ & $\begin{array}{r}2 \mathrm{R}-1 \\
79-81\end{array}$ & $\begin{array}{r}3 R-1 \\
26-28\end{array}$ & $\begin{array}{c}3 \mathrm{R}-4 \\
120-122\end{array}$ & $\begin{array}{l}5 \mathrm{R}-\mathrm{CC} \\
22-24\end{array}$ & $\begin{array}{l}\text { 7R-3 } \\
15-17\end{array}$ & $\begin{array}{l}42 \mathrm{R}-1 \\
81-84\end{array}$ & $\begin{array}{c}43 \mathrm{R}-2 \\
6081-8468\end{array}$ \\
\hline Depth (mbsf): & 375.05 & 359.89 & 368.96 & 373.99 & 388.8 & 409.69 & 744.71 & 745.52 \\
\hline \multicolumn{9}{|l|}{ Oxides (wt\%): } \\
\hline $\mathrm{SiO}_{2}$ & 49.08 & 39.34 & 45.19 & 41.85 & 58.48 & 40.32 & 46.04 & 46.70 \\
\hline $\mathrm{Al}_{2} \mathrm{O}_{3}$ & 12.52 & 12.08 & 12.40 & 11.59 & 14.17 & 11.89 & 18.93 & 18.22 \\
\hline $\mathrm{Fe}_{2} \mathrm{O}_{3}$ & 4.34 & 5.91 & 5.51 & 5.21 & 3.88 & 6.27 & 15.64 & 16.47 \\
\hline $\mathrm{MgO}$ & 4.14 & 3.65 & 3.54 & 4.55 & 3.27 & 3.29 & 3.47 & 3.48 \\
\hline $\mathrm{CaO}$ & 10.55 & 16.79 & 13.02 & 14.59 & 6.17 & 16.17 & 1.78 & 1.92 \\
\hline $\mathrm{Na}_{2} \mathrm{O}$ & 3.17 & 2.64 & 2.86 & 2.66 & 3.73 & 2.59 & 2.21 & 2.12 \\
\hline $\mathrm{K}_{2} \mathrm{O}$ & 2.569 & 0.990 & 1.662 & 1.512 & 2.934 & 1.532 & 0.340 & 0.325 \\
\hline $\mathrm{TiO}_{2}$ & 0.541 & 0.634 & 0.620 & 0.560 & 0.520 & 0.691 & 1.802 & 2.174 \\
\hline $\mathrm{MnO}$ & 0.104 & 0.085 & 0.077 & 0.114 & 0.064 & 0.091 & 0.152 & 0.190 \\
\hline $\mathrm{P}_{2} \mathrm{O}_{5}$ & 0.190 & 0.191 & 0.182 & 0.184 & 0.210 & 0.196 & 0.105 & 0.094 \\
\hline LOI & 12.98 & 17.16 & 14.86 & 16.65 & 6.01 & 16.73 & 9.34 & 8.59 \\
\hline Total & 100.18 & 99.47 & 99.92 & 99.47 & 99.44 & 99.77 & 99.81 & 100.28 \\
\hline \multicolumn{9}{|c|}{ Trace elements (ppm): } \\
\hline $\mathrm{Ba}$ & 500.4 & 686.5 & 399.6 & 497.6 & 519.1 & 792.2 & 355.7 & 152.1 \\
\hline V & 145.5 & 103.1 & 145 & 129.2 & 122.3 & 85 & 200.4 & 392.9 \\
\hline La & 18.2 & 14.3 & 12.1 & 14.2 & 17.2 & 13.3 & 10.4 & 5.3 \\
\hline $\mathrm{Ce}$ & 45.7 & 33.1 & 35.3 & 38.0 & 39.1 & 35.7 & 28.6 & 20.2 \\
\hline $\mathrm{Nd}$ & 18.1 & 16.1 & 16.1 & 16.1 & 17.0 & 15.3 & 20.3 & 15.0 \\
\hline $\mathrm{Cr}$ & 144.2 & 144.1 & 150.5 & 134.4 & 138.7 & 111.9 & 241 & 245.4 \\
\hline $\mathrm{Ni}$ & 77 & 78.8 & 80.6 & 73.1 & 79.2 & 60.5 & 102.8 & 99.1 \\
\hline $\mathrm{Cu}$ & 52.9 & 37.3 & 58.3 & 53.8 & 49.6 & 29.1 & 87.2 & 97.9 \\
\hline $\mathrm{Zn}$ & 68.8 & 59.2 & 70.5 & 71.4 & 61.5 & 53.1 & 73.8 & 108.3 \\
\hline $\mathrm{Pb}$ & 17.2 & 30.1 & 18.5 & 17.9 & 22.4 & 23.3 & 15.9 & 14.5 \\
\hline $\mathrm{Rb}$ & 3.8 & 3.5 & 3.6 & 3.4 & 3.9 & 3.8 & 5.8 & 5.7 \\
\hline $\mathrm{Sr}$ & 760.7 & 867.9 & 744.3 & 783.4 & 788.9 & 872.9 & 239.0 & 229.5 \\
\hline Y & 11.0 & 9.3 & 11.8 & 10.8 & 9.6 & 10.0 & 15.5 & 34.3 \\
\hline $\mathrm{Zr}$ & 94.9 & 125.0 & 89.7 & 102.4 & 98.1 & 123.1 & 128.3 & 126.8 \\
\hline $\mathrm{Nb}$ & 3.8 & 3.5 & 3.6 & 3.4 & 3.9 & 3.8 & 5.8 & 5.7 \\
\hline
\end{tabular}


Table T4. X-ray fluorescence analysis of major elements and trace elements, Site 1118. (Continued on next page.)

\begin{tabular}{|c|c|c|c|c|c|c|c|c|c|c|c|c|c|c|c|c|c|c|c|}
\hline $\begin{array}{l}\text { Core, section, } \\
\text { interval }(\mathrm{cm}) \text { : }\end{array}$ & $\begin{array}{c}31 \mathrm{R}-\mathrm{CC} \\
11-13\end{array}$ & $\begin{array}{l}33 \mathrm{R}-3, \\
48-60\end{array}$ & $\begin{array}{l}35 \mathrm{R}-1 \\
11-13\end{array}$ & $\begin{array}{c}37 \mathrm{R}-5 \\
3-5\end{array}$ & $\begin{array}{l}38 \mathrm{R}-5 \\
16-19\end{array}$ & $\begin{array}{l}39 \mathrm{R}-1 \\
37-39\end{array}$ & $\begin{array}{l}41 \mathrm{R}-5 \\
35-38\end{array}$ & $\begin{array}{l}43 \mathrm{R}-4, \\
45-47\end{array}$ & $\begin{array}{l}45 \mathrm{R}-2, \\
69-71\end{array}$ & $\begin{array}{l}47 \mathrm{R}-2 \\
85-86\end{array}$ & $\begin{array}{c}\text { 49R-1, } \\
103-105\end{array}$ & $\begin{array}{l}51 \mathrm{R}-3 \\
34-36\end{array}$ & $\begin{array}{c}53-1 \\
123-124\end{array}$ & $\begin{array}{l}55 \mathrm{R}-2 \\
12-14\end{array}$ & $\begin{array}{l}57 \mathrm{R}-5, \\
62-65\end{array}$ & $\begin{array}{l}59 \mathrm{R}-4, \\
23-25\end{array}$ & $\begin{array}{l}61 \mathrm{R}-3, \\
26-28\end{array}$ & $\begin{array}{l}65 \mathrm{R}-2 \\
29-31\end{array}$ & $\begin{array}{l}\text { 66R-3, } \\
86-88\end{array}$ \\
\hline Depth (mbsf): & 501.53 & 515.43 & $531-51$ & 566.12 & 629.64 & 629.64 & 629.64 & 629.64 & 629.64 & 649.13 & 667.03 & 687.83 & 705.93 & 725.09 & 749.4 & 767.03 & 748.72 & 822.02 & 833.6 \\
\hline \multicolumn{20}{|l|}{ Oxides (wt\%): } \\
\hline $\mathrm{SiO}_{2}$ & 50.85 & 50.42 & 48.62 & 38.14 & 47.03 & 46.78 & 53.61 & 45.61 & 41.83 & 49.30 & 41.21 & 27.60 & 50.41 & 44.46 & 42.02 & 61.29 & 39.70 & 47.15 & 54.73 \\
\hline $\mathrm{Al}_{2} \mathrm{O}_{3}$ & 13.73 & 13.34 & 12.67 & 10.19 & 13.38 & 13.29 & 15.11 & 14.67 & 12.94 & 13.41 & 11.73 & 8.41 & 13.88 & 12.35 & 12.32 & 14.12 & 11.58 & 12.91 & 14.74 \\
\hline $\mathrm{Fe}_{2} \mathrm{O}_{3}$ & 5.55 & 8.46 & 8.10 & 6.08 & 6.62 & 7.51 & 5.15 & 5.20 & 5.91 & 6.68 & 5.56 & 4.24 & 6.35 & 5.72 & 6.35 & 3.71 & 5.62 & 5.07 & 5.53 \\
\hline $\mathrm{MgO}$ & 3.79 & 5.71 & 6.79 & 4.06 & 3.98 & 4.56 & 3.89 & 3.18 & 3.33 & 3.57 & 3.17 & 2.61 & 4.19 & 3.64 & 3.55 & 2.86 & 3.26 & 3.37 & 3.58 \\
\hline $\mathrm{CaO}$ & 8.99 & 6.82 & 8.24 & 18.02 & 10.71 & 9.64 & 5.90 & 12.08 & 14.33 & 8.98 & 16.31 & 27.06 & 8.45 & 13.76 & 14.55 & 4.50 & 17.15 & 12.22 & 6.26 \\
\hline $\mathrm{Na}_{2} \mathrm{O}$ & 3.10 & 3.13 & 3.12 & 2.17 & 2.81 & 2.82 & 3.50 & 3.16 & 2.69 & 2.97 & 2.45 & 2.66 & 3.28 & 2.61 & 2.44 & 3.69 & 2.31 & 2.86 & 3.36 \\
\hline $\mathrm{K}_{2} \mathrm{O}$ & 2.080 & 1.587 & 1.367 & 1.098 & 1.861 & 1.701 & 3.152 & 1.980 & 1.869 & 2.406 & 1.503 & 1.016 & 1.992 & 1.560 & 1.416 & 3.278 & 1.271 & 1.880 & 2.466 \\
\hline $\mathrm{TiO}_{2}$ & 0.638 & 0.751 & 0.527 & 0.565 & 0.763 & 0.733 & 0.623 & 0.623 & 0.577 & 0.776 & 0.619 & 0.466 & 0.706 & 0.645 & 0.703 & 0.488 & 0.689 & 0.651 & 0.677 \\
\hline $\mathrm{MnO}$ & 0.076 & 0.108 & 0.115 & 0.109 & 0.086 & 0.080 & 0.068 & 0.086 & 0.102 & 0.065 & 0.122 & 0.098 & 0.074 & 0.108 & 0.097 & 0.067 & 0.108 & 0.087 & 0.037 \\
\hline $\mathrm{P}_{2} \mathrm{O}_{5}$ & 0.178 & 0.150 & 0.241 & 0.169 & 0.157 & 0.143 & 0.240 & 0.266 & 0.245 & 0.155 & 0.214 & 0.202 & 0.165 & 0.176 & 0.184 & 0.221 & 0.181 & 0.207 & 0.142 \\
\hline LOI & 10.71 & 9.29 & 9.66 & 18.85 & 12.80 & 12.14 & 8.51 & 12.93 & 15.60 & 11.38 & 16.64 & 25.73 & 10.24 & 14.48 & 16.08 & 5.48 & 17.63 & 13.05 & 8.01 \\
\hline Total & 99.69 & 99.77 & 99.45 & 99.45 & 100.20 & 99.40 & 99.75 & 99.79 & 99.42 & 99.69 & 99.53 & 100.09 & 99.74 & 99.51 & 99.71 & 99.70 & 99.50 & 99.46 & 99.53 \\
\hline \multicolumn{20}{|c|}{ Trace elements (ppm): } \\
\hline $\mathrm{Ba}$ & 562.1 & 293.5 & 215.2 & 231.6 & 443.5 & 361.9 & 875.3 & 695.3 & 571.6 & 564.2 & 428.9 & 253.9 & 497.1 & 411.9 & 377.9 & 876.2 & 350 & 566.8 & 674.7 \\
\hline V & 132.2 & 185 & 173.6 & 158.8 & 159.1 & 177.1 & 95.7 & 134.5 & 127.1 & 188.7 & 147.7 & 125.6 & 143.6 & 149.7 & 175.2 & 72.1 & 167.6 & 138.8 & 146.6 \\
\hline La & 14.2 & 9.4 & 5.7 & 8.9 & 20.7 & 17.0 & 25.7 & 19.4 & 24.2 & 12.5 & 10.1 & 11.2 & 13.8 & 9.6 & 9.5 & 19.4 & 10.5 & 18.1 & 16.7 \\
\hline $\mathrm{Ce}$ & 38.9 & 30.9 & 20.9 & 29.0 & 49.3 & 40.0 & 58.5 & 49.6 & 42.0 & 38.7 & 31.7 & 28.5 & 38.4 & 34.3 & 34.2 & 44.6 & 30.7 & 38.3 & 41.4 \\
\hline $\mathrm{Nd}$ & 18 & 15.2 & 10.5 & 12.1 & 24.3 & 18.5 & 24.5 & 21.3 & 17.5 & 16.8 & 14.5 & 14.2 & 16.9 & 14.7 & 17.0 & 16.8 & 13.8 & 18.3 & 19.7 \\
\hline $\mathrm{Cr}$ & 164.4 & 206.7 & 207.4 & 188.1 & 261.8 & 259.1 & 159.2 & 119.5 & 124 & 240 & 140.3 & 127 & 175.5 & 141.9 & 173.9 & 83.6 & 158.4 & 137.8 & 229.6 \\
\hline $\mathrm{Ni}$ & 84.6 & 101.2 & 100.4 & 70.5 & 92.3 & 113.8 & 94.3 & 67.3 & 69.1 & 109.1 & 68.1 & 80.9 & 89.9 & 66.5 & 79.5 & 63.7 & 63.7 & 63.3 & 106.1 \\
\hline $\mathrm{Cu}$ & 52.8 & 91.6 & 61.6 & 71.4 & 71.6 & 76.6 & 37.2 & 104.2 & 84.3 & 59.1 & 64.2 & 63 & 59.9 & 58.9 & 63.7 & 31.8 & 68 & 57.4 & 48 \\
\hline $\mathrm{Zn}$ & 66.5 & 75.6 & 67.3 & 59 & 70.2 & 73.3 & 62.7 & 64.3 & 61.1 & 69.1 & 65.3 & 59.5 & 68.9 & 67.4 & 75.5 & 51.7 & 74.4 & 73.2 & 68.5 \\
\hline $\mathrm{Pb}$ & 24.5 & 13.4 & 9.9 & 9.5 & 22.4 & 16.5 & 49 & 24.6 & 22.5 & 24.9 & 16.3 & 12.6 & 20.8 & 16.2 & 15.2 & 30 & 13 & 19.8 & 38.5 \\
\hline $\mathrm{Rb}$ & 56.8 & 37.5 & 27.7 & 30.8 & 43.0 & 38.6 & 74.1 & 43.4 & 44.6 & 57.1 & 39.2 & 23.5 & 51.7 & 46.7 & 46.0 & 68.0 & 41.6 & 53.7 & 61.5 \\
\hline $\mathrm{Sr}$ & 749.9 & 441.0 & 398.3 & 885.6 & 728.4 & 621.9 & 630.5 & 964.6 & 874.5 & 866.6 & 895.8 & 1127.6 & 728.0 & 792.5 & 857.2 & 648.4 & 918.4 & 918.1 & 995.0 \\
\hline Y & 10.9 & 15.4 & 10.4 & 12.1 & 15.0 & 14.0 & 10.1 & 11.8 & 11.8 & 12.8 & 12.3 & 9.9 & 11.1 & 12.8 & 12.6 & 8.9 & 12.5 & 11.5 & 10.5 \\
\hline $\mathrm{Zr}$ & 121.3 & 109.8 & 82.6 & 77.1 & 123.1 & 115.7 & 162.6 & 106.3 & 112.0 & 117.5 & 84.6 & 65.1 & 115.5 & 90.3 & 89.3 & 131.4 & 84.2 & 100.9 & 147.3 \\
\hline $\mathrm{Nb}$ & 4.0 & 3.7 & 2.6 & 2.8 & 4.6 & 4.1 & 4.2 & 3.6 & 3.7 & 3.9 & 3.4 & 2.8 & 4.3 & 3.6 & 4.0 & 4.2 & 3.5 & 3.9 & 4.5 \\
\hline
\end{tabular}

Note: $\mathrm{LOI}=$ loss on ignition . 
Table T4 (continued).

\begin{tabular}{lcccc}
\hline Core, section, & $57 \mathrm{R}-\mathrm{CC}$, & $68 \mathrm{R}-1$, & $70 \mathrm{R}-3$, & $74 \mathrm{R}-3$, \\
interval (cm): & $39-41$ & $88-90$ & $35-37$ & $31-33$ \\
Depth (mbsf): & 845.89 & 850.18 & 871.6 & 900.75 \\
\hline Oxides (wt\%): & & & & \\
$\mathrm{SiO}_{2}$ & 45.24 & 44.42 & 49.57 & 46.77 \\
$\mathrm{Al}_{2} \mathrm{O}_{3}$ & 12.79 & 12.22 & 14.11 & 16.17 \\
$\mathrm{Fe}_{2} \mathrm{O}_{3}$ & 4.43 & 4.17 & 15.49 & 19.51 \\
$\mathrm{MgO}$ & 3.25 & 2.79 & 6.35 & 3.06 \\
$\mathrm{CaO}$ & 15.05 & 16.13 & 3.84 & 1.36 \\
$\mathrm{Na}_{2} \mathrm{O}$ & 2.90 & 2.93 & 3.41 & 2.35 \\
$\mathrm{~K}_{2} \mathrm{O}$ & 1.972 & 1.949 & 0.648 & 0.729 \\
$\mathrm{TiO}$ & 0.542 & 0.535 & 1.863 & 1.949 \\
$\mathrm{MnO}$ & 0.057 & 0.051 & 0.139 & 0.087 \\
$\mathrm{P}_{2} \mathrm{O}_{5}$ & 0.192 & 0.192 & 0.091 & 0.041 \\
$\mathrm{LOI}$ & 13.46 & 14.01 & 4.04 & 7.93 \\
$\mathrm{Total}$ & 99.88 & 99.40 & 99.55 & 99.96 \\
$\mathrm{Trace}$ elements & $(\mathrm{ppm}):$ & & & \\
$\mathrm{Ba}$ & 604.9 & 608.5 & 44.7 & 37.3 \\
$\mathrm{~V}$ & 128.6 & 126.8 & 408.1 & 477.7 \\
$\mathrm{La}$ & 15.6 & 13.3 & 5.2 & 2.4 \\
$\mathrm{Ce}$ & 39.3 & 36.9 & 19.9 & 12.0 \\
$\mathrm{Nd}$ & 20.2 & 17.3 & 13.4 & 9.0 \\
$\mathrm{Cr}$ & 148.7 & 157.2 & 87.1 & 166.8 \\
$\mathrm{Ni}$ & 65.9 & 68.4 & 72.7 & 65.3 \\
$\mathrm{Cu}$ & 46.2 & 38.8 & 79 & 79.4 \\
$\mathrm{Zn}$ & 58.3 & 59.7 & 81.1 & 85.1 \\
$\mathrm{~Pb}$ & 21 & 18.6 & 4.1 & 1.6 \\
$\mathrm{Rb}$ & 44.5 & 41.1 & 10.4 & 4.7 \\
$\mathrm{Sr}$ & 1307.1 & 1411.2 & 256.2 & 122.4 \\
$\mathrm{Y}$ & 9.9 & 9.0 & 32.1 & 22.1 \\
$\mathrm{Zr}$ & 109.3 & 97.9 & 110.7 & 104.3 \\
$\mathrm{Nb}$ & 3.6 & 3.5 & 5.7 & 5.5 \\
\hline & & & & \\
\hline & & &
\end{tabular}


A.H.F. ROBERTSON AND T.R. SHARP

MiXed Volcanogenic/Terrigenous Hemipelagic SEDiments

Table T5. X-ray fluorescence analysis of major elements and trace elements, Site 1108.

\begin{tabular}{|c|c|c|c|c|c|c|c|}
\hline $\begin{array}{l}\text { Core, section, } \\
\text { interval }(\mathrm{cm}) \text { : }\end{array}$ & $\begin{array}{l}\text { 16R-1, } \\
67-68\end{array}$ & $\begin{array}{c}\text { 20R-1, } \\
138-141\end{array}$ & $\begin{array}{c}\text { 24-1, } \\
99-100\end{array}$ & $\begin{array}{l}32 \mathrm{R}-3 \\
82-84\end{array}$ & $\begin{array}{c}36-4 \\
20-22\end{array}$ & $\begin{array}{l}40 \mathrm{R}-1 \\
18-20\end{array}$ & $\begin{array}{c}\text { 45R-1, } \\
107-109\end{array}$ \\
\hline Depth (mbsf): & 140.07 & 179.38 & 218.83 & 295.87 & 355.09 & 369.98 & 428.58 \\
\hline \multicolumn{8}{|l|}{ Oxides (wt\%): } \\
\hline $\mathrm{SiO}_{2}$ & 48.38 & 52.15 & 50.25 & 49.95 & 53.71 & 42.86 & 56.47 \\
\hline $\mathrm{Al}_{2} \mathrm{O}_{3}$ & 14.85 & 14.86 & 15.18 & 14.38 & 17.36 & 12.31 & 16.14 \\
\hline $\mathrm{Fe}_{2} \mathrm{O}_{3}$ & 10.62 & 9.51 & 10.90 & 11.49 & 6.47 & 6.11 & 6.19 \\
\hline $\mathrm{MgO}$ & 6.94 & 6.57 & 7.02 & 8.60 & 5.01 & 3.61 & 4.36 \\
\hline $\mathrm{CaO}$ & 5.12 & 4.38 & 3.51 & 3.46 & 4.52 & 14.81 & 4.94 \\
\hline $\mathrm{Na}_{2} \mathrm{O}$ & 2.70 & 3.19 & 2.79 & 2.76 & 3.79 & 2.32 & 3.83 \\
\hline $\mathrm{K}_{2} \mathrm{O}$ & 1.248 & 1.259 & 1.354 & 1.051 & 2.659 & 1.477 & 1.830 \\
\hline $\mathrm{TiO}_{2}$ & 0.980 & 0.996 & 0.901 & 1.063 & 1.053 & 0.718 & 0.943 \\
\hline $\mathrm{MnO}$ & 0.136 & 0.088 & 0.103 & 0.081 & 0.095 & 0.252 & 0.051 \\
\hline $\mathrm{P}_{2} \mathrm{O}_{5}$ & 0.142 & 0.113 & 0.130 & 0.114 & 0.306 & 1.284 & 0.271 \\
\hline LOI & 8.80 & 6.28 & 7.70 & 7.24 & 4.48 & 14.05 & 4.60 \\
\hline Total & 99.92 & 99.40 & 99.84 & 100.19 & 99.45 & 99.80 & 99.63 \\
\hline \multicolumn{8}{|c|}{ Trace elements (ppm): } \\
\hline $\mathrm{Ba}$ & 250.2 & 264.6 & 248.9 & 225.1 & 744.7 & 369 & 614.2 \\
\hline V & 217.3 & 238.1 & 216.9 & 257 & 140.4 & 224 & 167.4 \\
\hline La & 10.9 & 6.3 & 8.8 & 9.6 & 32.1 & 16 & 18.2 \\
\hline $\mathrm{Ce}$ & 34.5 & 21.1 & 26.7 & 26.4 & 76.0 & 44 & 50.0 \\
\hline $\mathrm{Nd}$ & 18.8 & 11.1 & 14.8 & 12.5 & 35.2 & 21 & 23.3 \\
\hline $\mathrm{Cr}$ & 282.8 & 382.1 & 350.7 & 283.4 & 197.3 & 379 & 321.2 \\
\hline $\mathrm{Ni}$ & 182.9 & 178.3 & 207.4 & 297.9 & 95.2 & 115 & 108.7 \\
\hline $\mathrm{Cu}$ & 122.7 & 91.8 & 120.6 & 129.6 & 55.7 & 74 & 53.1 \\
\hline $\mathrm{Zn}$ & 9 & 8.6 & 13.9 & 9.3 & 16.2 & 14 & 12.4 \\
\hline $\mathrm{Pb}$ & 34.8 & 34.9 & 38.7 & 29.6 & 48.8 & 34 & 40.2 \\
\hline $\mathrm{Rb}$ & 459.7 & 506.8 & 424.4 & 296.8 & 581.9 & 730 & 644.8 \\
\hline $\mathrm{Sr}$ & 20.7 & 17.9 & 17.1 & 19.9 & 29.7 & 20 & 17.8 \\
\hline$Y$ & 125 & 101 & 115.3 & 113.4 & 226.9 & 161 & 194.2 \\
\hline $\begin{array}{l}\mathrm{Zr} \\
\mathrm{Nb}\end{array}$ & 5.6 & 4 & 4.4 & 5 & 9.2 & 3.9 & 7.9 \\
\hline
\end{tabular}

Note: $\mathrm{LOI}=$ loss on ignition. 
A.H.F. ROBERTSON AND T.R. SHARP

Mixed VolCanogenic/TerRigenous Hemipelagic SEDiments

Table T6. X-ray fluorescence analysis of major elements and trace elements, Site 1114.

\begin{tabular}{|c|c|c|c|c|c|c|}
\hline $\begin{array}{l}\text { Core, section, } \\
\text { interval }(\mathrm{cm}) \text { : }\end{array}$ & $\begin{array}{l}8 \mathrm{R}-1 \\
54-55\end{array}$ & $\begin{array}{c}11-C C \\
10-12\end{array}$ & $\begin{array}{l}12 \mathrm{R}-1 \\
62-64\end{array}$ & $\begin{array}{c}\text { 16R-CC } \\
5-7\end{array}$ & $\begin{array}{l}22 \mathrm{R}-1 \\
13-14\end{array}$ & $\begin{array}{l}26 \mathrm{R}-1 \\
15-18\end{array}$ \\
\hline Depth (cm): & 65.14 & 95.02 & 122.9 & 141.85 & 199.53 & 237.76 \\
\hline \multicolumn{7}{|l|}{ Oxides (wt\%): } \\
\hline $\mathrm{SiO}_{2}$ & 50.22 & 15.15 & 55.84 & 53.20 & 48.54 & 51.48 \\
\hline $\mathrm{Al}_{2} \mathrm{O}_{3}$ & 15.62 & 4.37 & 17.82 & 14.86 & 14.62 & 14.06 \\
\hline $\mathrm{Fe}_{2} \mathrm{O}_{3}$ & 11.27 & 2.07 & 6.05 & 9.58 & 11.88 & 8.27 \\
\hline $\mathrm{MgO}$ & 5.58 & 1.46 & 3.64 & 5.10 & 6.03 & 4.91 \\
\hline $\mathrm{CaO}$ & 3.66 & 39.73 & 5.60 & 4.79 & 4.92 & 5.75 \\
\hline $\mathrm{Na}_{2} \mathrm{O}$ & 2.94 & 1.09 & 4.09 & 3.42 & 2.83 & 3.09 \\
\hline $\mathrm{K}_{2} \mathrm{O}$ & 1.230 & 0.190 & 2.030 & 1.740 & 1.500 & 3.248 \\
\hline $\mathrm{TiO}_{2}$ & 1.088 & 0.284 & 1.101 & 1.067 & 1.023 & 0.852 \\
\hline $\mathrm{MnO}$ & 0.131 & 0.043 & 0.047 & 0.085 & 0.164 & 0.120 \\
\hline $\mathrm{P}_{2} \mathrm{O}_{5}$ & 0.129 & 0.138 & 0.408 & 0.187 & 0.326 & 0.191 \\
\hline LOI & 8.00 & 34.88 & 2.82 & 5.95 & 8.08 & 7.47 \\
\hline Total & 99.87 & 99.41 & 99.54 & 99.93 & 99.87 & 99.44 \\
\hline \multicolumn{7}{|c|}{ Trace elements (ppm): } \\
\hline $\mathrm{Ba}$ & 82.8 & 267.4 & 469.5 & 127.7 & 753.5 & 200.7 \\
\hline $\mathrm{V}$ & 425.6 & 268.1 & 164.9 & 273.4 & 137.9 & 270.3 \\
\hline $\mathrm{La}$ & 8.7 & 4.7 & 29.6 & 6.7 & 8.4 & 10.8 \\
\hline $\mathrm{Ce}$ & 28.5 & 23.0 & 66.3 & 27.2 & 30.4 & 37.9 \\
\hline $\mathrm{Nd}$ & 16.2 & 13.1 & 31.9 & 14.3 & 18.4 & 20.0 \\
\hline $\mathrm{Cr}$ & 228.2 & 288.8 & 157.6 & 250.6 & 240.9 & 219.1 \\
\hline $\mathrm{Ni}$ & 99.7 & 114.7 & 79.4 & 124.6 & 115.3 & 108.9 \\
\hline $\mathrm{Cu}$ & 108.4 & 97.7 & 70 & 160.9 & 43.7 & 150.5 \\
\hline $\mathrm{Zn}$ & 113.6 & 83.6 & 77.2 & 94.3 & 71.5 & 96.5 \\
\hline $\mathrm{Pb}$ & 6 & 10.2 & 17.3 & 10.4 & 16.1 & 13.3 \\
\hline $\mathrm{Rb}$ & 4.5 & 1.9 & 10.0 & 4.8 & 4.7 & 5.1 \\
\hline $\mathrm{Sr}$ & 210.5 & 1554.9 & 801.6 & 375.5 & 291.7 & 448.1 \\
\hline$Y$ & 30.6 & 15.7 & 12.2 & 22.0 & 21.0 & 25.8 \\
\hline $\mathrm{Zr}$ & 105.2 & 111.4 & 89.2 & 109.8 & 255.3 & 109.4 \\
\hline $\mathrm{Nb}$ & 4.5 & 1.9 & 1.8 & 4.8 & 4.7 & 5.1 \\
\hline
\end{tabular}

Note: $\mathrm{LOI}=$ loss on ignition. 
A.H.F. ROBERTSON AND T.R. SHARP

Mixed VolCanogenic/TerRigenous Hemipelagic SEDiments

Table T7. X-ray fluorescence analysis of major elements and trace elements, Site 1116.

\begin{tabular}{|c|c|c|c|c|c|c|}
\hline $\begin{array}{l}\text { Core, section, } \\
\text { interval }(\mathrm{cm}) \text { : }\end{array}$ & $\begin{array}{l}3 \mathrm{R}-\mathrm{CC} \\
15-18\end{array}$ & $\begin{array}{c}5 \mathrm{R}-1 \\
108-110\end{array}$ & $\begin{array}{c}1 \mathrm{R}-1 \\
130-133\end{array}$ & $\begin{array}{c}12 \mathrm{R}-1 \\
8-10\end{array}$ & $\begin{array}{c}14 \mathrm{R}-1 \\
112-114\end{array}$ & $\begin{array}{l}\text { 18R-1, } \\
77-79\end{array}$ \\
\hline Depth (mbsf): & 17.05 & 51.54 & 63.9 & 91.48 & 111.72 & 150.07 \\
\hline \multicolumn{7}{|l|}{ Oxides (wt\%): } \\
\hline $\mathrm{SiO}_{2}$ & 49.85 & 51.54 & 58.47 & 48.43 & 49.68 & 55.56 \\
\hline $\mathrm{Al}_{2} \mathrm{O}_{3}$ & 15.18 & 14.52 & 14.79 & 15.47 & 15.86 & 15.46 \\
\hline $\mathrm{Fe}_{2} \mathrm{O}_{3}$ & 10.67 & 11.18 & 7.10 & 11.86 & 12.13 & 6.97 \\
\hline $\mathrm{MgO}$ & 5.45 & 6.16 & 4.58 & 5.50 & 5.75 & 4.4 \\
\hline $\mathrm{CaO}$ & 5.01 & 4.12 & 4.86 & 4.22 & 3.2 & 5.16 \\
\hline $\mathrm{Na}_{2} \mathrm{O}$ & 3.16 & 3.25 & 3.60 & 2.85 & 3.64 & 3.54 \\
\hline $\mathrm{K}_{2} \mathrm{O}$ & 1.528 & 1.188 & 1.729 & 1.045 & 1.184 & 3.369 \\
\hline $\mathrm{TiO}_{2}$ & 1.028 & 0.944 & 1.055 & 1.057 & 1.011 & 0.965 \\
\hline $\mathrm{MnO}$ & 0.109 & 0.125 & 0.069 & 0.108 & 0.114 & 0.059 \\
\hline $\mathrm{P}_{2} \mathrm{O}_{5}$ & 0.200 & 0.109 & 0.171 & 0.174 & 0.151 & 0.373 \\
\hline LOI & 7.30 & 6.77 & 3.52 & 8.93 & 7.55 & 5.2 \\
\hline Total & 99.49 & 99.91 & 99.94 & 99.64 & 11.27 & 100.16 \\
\hline \multicolumn{7}{|c|}{ Trace elements (ppm): } \\
\hline $\mathrm{Ba}$ & 132.8 & 369.1 & 145.6 & 178.5 & 178.5 & 624.8 \\
\hline V & 259.3 & 232.8 & 228.5 & 266.1 & 9.1 & 31.4 \\
\hline $\mathrm{La}$ & 6.1 & 10.8 & 6.7 & 8.3 & 8.3 & 29.4 \\
\hline $\mathrm{Ce}$ & 21.2 & 30.9 & 25.9 & 28.1 & 28.1 & 68.5 \\
\hline $\mathrm{Nd}$ & 10.9 & 15.9 & 14.7 & 16.2 & 16.2 & 33.5 \\
\hline $\mathrm{Cr}$ & 184.6 & 459.6 & 185.2 & 224.5 & 224.5 & 1881.1 \\
\hline $\mathrm{Ni}$ & 79.8 & 139.5 & 82.7 & 125.8 & 125.8 & 111 \\
\hline $\mathrm{Cu}$ & 133.8 & 54.7 & 93.9 & 172.9 & 172.9 & 70.8 \\
\hline $\mathrm{Zn}$ & 90.9 & 75.3 & 103.9 & 101 & 101 & 71.4 \\
\hline $\mathrm{Pb}$ & 6.4 & 12.4 & 10.4 & 15.5 & 15.5 & 15.1 \\
\hline $\mathrm{Rb}$ & 22.7 & 33.4 & 26.5 & 31.8 & 31.8 & 53.2 \\
\hline $\mathrm{Sr}$ & 512.0 & 235.1 & 201.7 & 593.1 & 201.7 & 593.1 \\
\hline$Y$ & 18.9 & 14.2 & 23.6 & 22.3 & 22.3 & 21.2 \\
\hline $\mathrm{Zr}$ & 90.6 & 120.3 & 105.6 & 102.6 & 102.6 & 247.8 \\
\hline $\mathrm{Nb}$ & 3.8 & 5.3 & 4.5 & 4.3 & 4.3 & 8.6 \\
\hline
\end{tabular}

Note: $\mathrm{LOI}=$ loss on ignition. 